\title{
Five Degrees of Separation: Characterization and Temperature Stability Profiles for the Polymorphs of PD-0118057 (Molecule XXIII)
}

Brian Samas, ${ }^{1}$ Wesley D. Clark, ${ }^{1}$ Ai-Fang Li, ${ }^{2}$ Frank C. Pickard IV ${ }^{1}$ and Geoffrey P. F. Wood ${ }^{1}$

1 Pharmaceutical Sciences, Pfizer Global Research \& Development, Groton, Connecticut 06340

2 Eurofins Lancaster Laboratories Professional Scientific Services, 2425 New Holland Pike, Lancaster, PA 17605

Corresponding Author: Brian Samas: brian.samas@pfizer.com

Additional authors: Wesley D. Clark: wesley.clark@pfizer.com, Ai-Fang Li: Ai-fang.li@pfizer.com, Frank C. Pickard IV: frank.pickard@ pfizer.com, Geoffrey P.F. Wood: geoffrey.wood@pfizer.com 


\section{Supporting Information}

\section{Table of Contents}

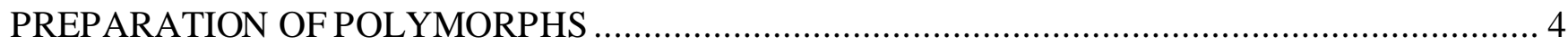

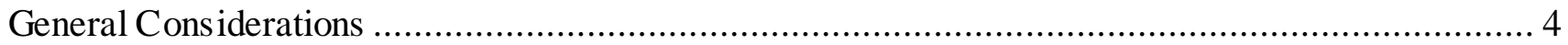

Form A

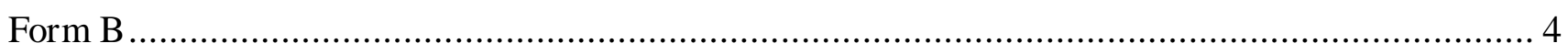

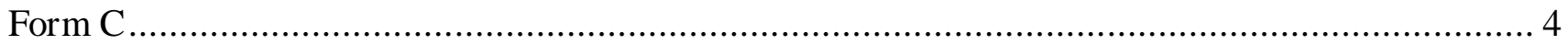

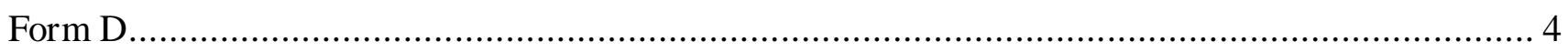

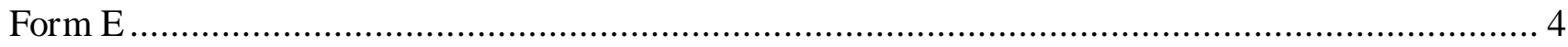

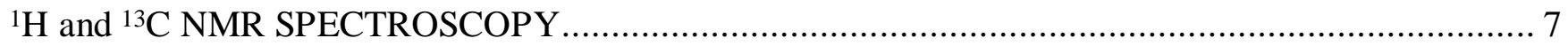

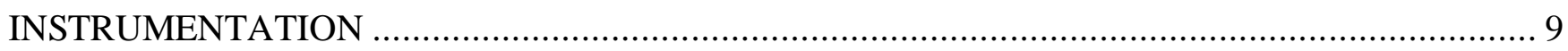

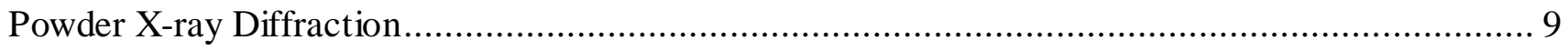

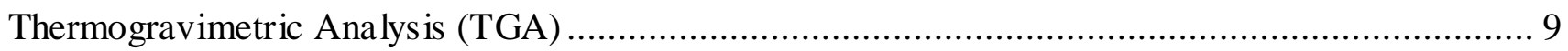

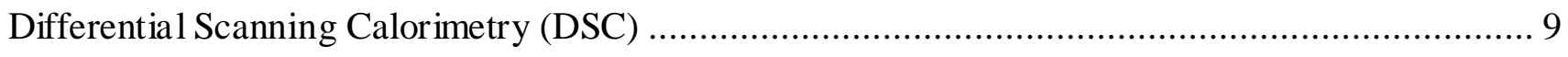

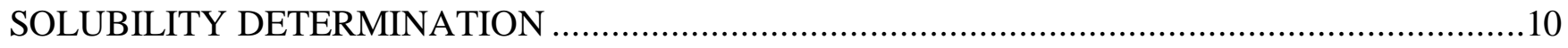

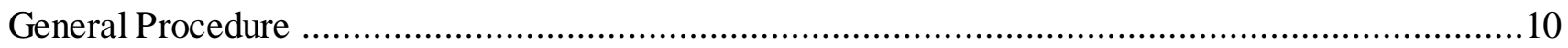

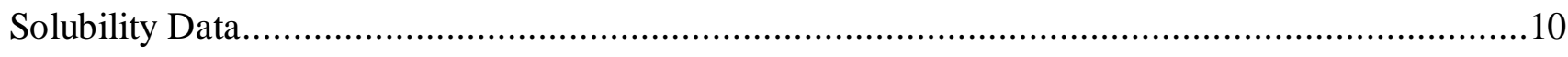

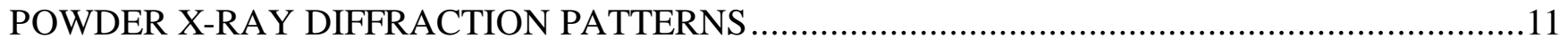

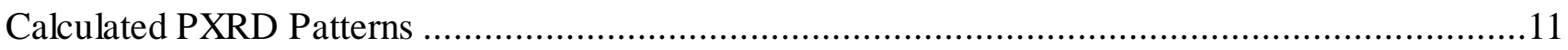

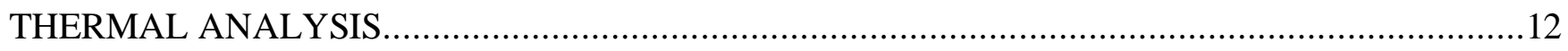

Thermogravimetric Analysis (TGA) ……...........................................................................

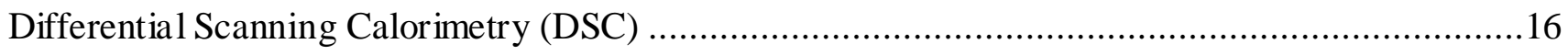

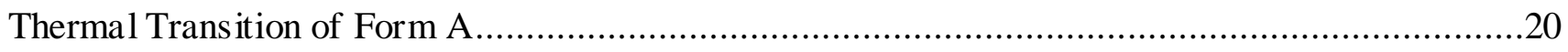

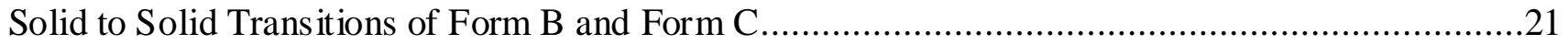

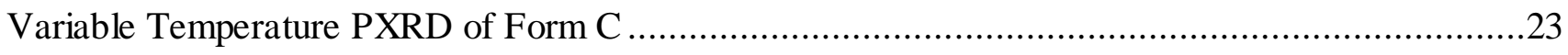

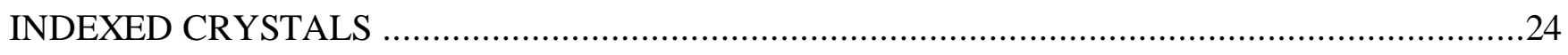

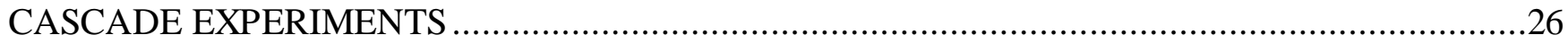

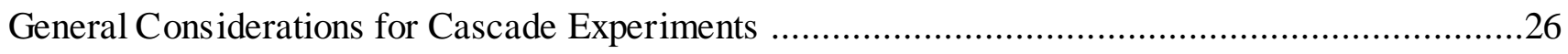

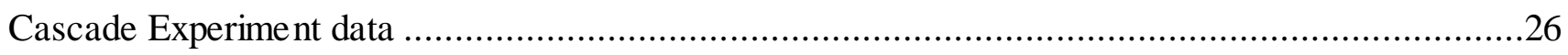

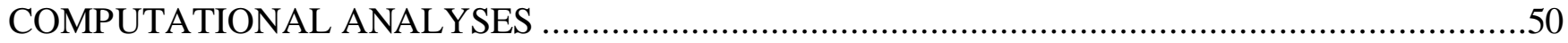


Five Degrees of Separation: Characterization and Temperature Stability Profiles for the Polymorphs of PD-0118057 (Molecule XXIII)- Supporting Information

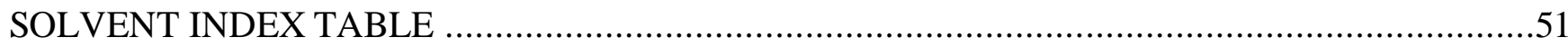

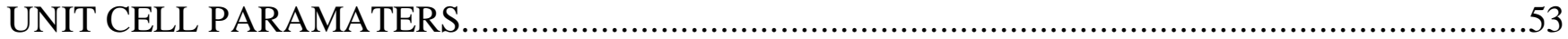




\section{PREPARATION OF POLYMORPHS}

\section{General Considerations}

No effort was made for the exclusion of air or moisture. All solvents were purchased from FisherScientific and used as received. Molecule XXIII was received from Pfizer Global Compound Management as a light yellow solid and used without further purification.

\section{Form A}

Molecule XXIII and ethyl acetate $(25.0 \mathrm{~mL})$ were stirred at $6{ }^{\circ} \mathrm{C}$. After 3 weeks of stirring, the solids were collected and dried in vacuo. $3.6619 \mathrm{~g}, 69 \%$.

\section{Form B}

Molecule XXIII Form D and ethyl acetate $(5.00 \mathrm{~mL})$ were stirred at $6{ }^{\circ} \mathrm{C}$. After 10 days of stirring, the solids were collected and dried in vacuo. $324.9 \mathrm{mg}, 65 \%$.

\section{Form C}

Molecule XXIII Form D $(101.3 \mathrm{mg})$ and ethyl acetate $(0.500 \mathrm{~mL})$ were stirred at $-15{ }^{\circ} \mathrm{C}$. After 5 days of stirring, the solids were collected and dried in vacuo.

\section{Form D}

Molecule XXIII $(3.0775 \mathrm{~g})$ and ethyl acetate $(10.0 \mathrm{~mL})$ were stirred at room temperature. After 2 weeks of stirring, the solids were collected and dried in vacuo. $2.1691 \mathrm{~g}, 70 \%$.

\section{Form E}

Crystals of Form E, suitable for SCXRD, were originally grown by heat/cool in mixture of acetone/water $(75 / 25)$ at a concentration of $50 \mathrm{mg} / \mathrm{mL}$. Since this time, Form E has not been reproduced or scaled successfully.

Form E Crystallization Efforts:

Form E was attempted by two different scientists

Experimenter 1:

Performed heat cool experiments in a crystal16 with approximately $1 \mathrm{~mL}$ volume per trial. Experimental details are given in Table S1 below. 
Table S 1. Summary of crystallization attempts to make Molecule XXIII Form E.

\begin{tabular}{|c|c|c|c|}
\hline Solvent & $\begin{array}{c}\text { Concentration } \\
(\mathrm{mg} / \mathrm{mL})\end{array}$ & $\begin{array}{c}\text { Max Temp } \\
\left({ }^{\circ} \mathrm{C}\right)\end{array}$ & Observations \\
\hline Acetone & 167 & 50 & $\begin{array}{c}\text { Formed a solid with } \\
\text { cooling. May not } \\
\text { have fully dissolved } \\
\text { with heating }\end{array}$ \\
\hline Ethyl Acetate & 117 & 70 & $\begin{array}{c}\text { Formed a solid with } \\
\text { cooling. }\end{array}$ \\
\hline MeOH & 20 & 60 & $\begin{array}{c}\text { Formed a solid with } \\
\text { cooling. }\end{array}$ \\
\hline Heptane & 8 & 80 & $\begin{array}{c}\text { Formed a solid with } \\
\text { cooling. }\end{array}$ \\
\hline Isopropanol & 21 & 80 & $\begin{array}{c}\text { Did not form a solid } \\
\text { immediately upon } \\
\text { cooling. But a solid } \\
\text { did form after } \\
\text { sitting at RT for } 24 \\
\text { hours. }\end{array}$ \\
\hline Acetonitrile & 19 & 80 & $\begin{array}{c}\text { Formed a solid with } \\
\text { cooling. }\end{array}$ \\
\hline
\end{tabular}

PXRD of solids isolated from all trials above were not consistent with Molecule XXIII Form E.

Experimenter 2:

1) $60 \mathrm{mg}$ of Form $\mathrm{D}$ was placed in an HPLC vial with a stir bar, $0.160 \mathrm{~mL}$ of acetone was added followed by $0.040 \mathrm{ml}$ of water. Allowed to stir on the crystall 6 for a hour at $40^{\circ} \mathrm{C}$, ramp down to $25^{\circ} \mathrm{C}$ over an hour, held at $25^{\circ} \mathrm{C}$ for one hour, ramped down to $5^{\circ} \mathrm{C}$ over an hour then held at $5^{\circ} \mathrm{C}$ for twelve hours. Solids were collected and found to be Form D.

2) $800 \mathrm{mg}$ of Form $\mathrm{D}$ was weighed up into a scintillation vial with a stir bar. $10 \mathrm{~mL}$ of Acetone was added. Form was monitored using inline Raman and was scanned every hour for the 5 days. A wet sample was taken for PXRD analysis. The sample was submerged in a dry ice 2-propanol bath. The sample was filtered by vacuum filtration and rinsed with MTBE. Resulting pattern was Form A. 
Five Degrees of Separation: Characterization and Temperature Stability Profiles for the Polymorphs of PD-0118057 (Molecule XXIII)- Supporting Information

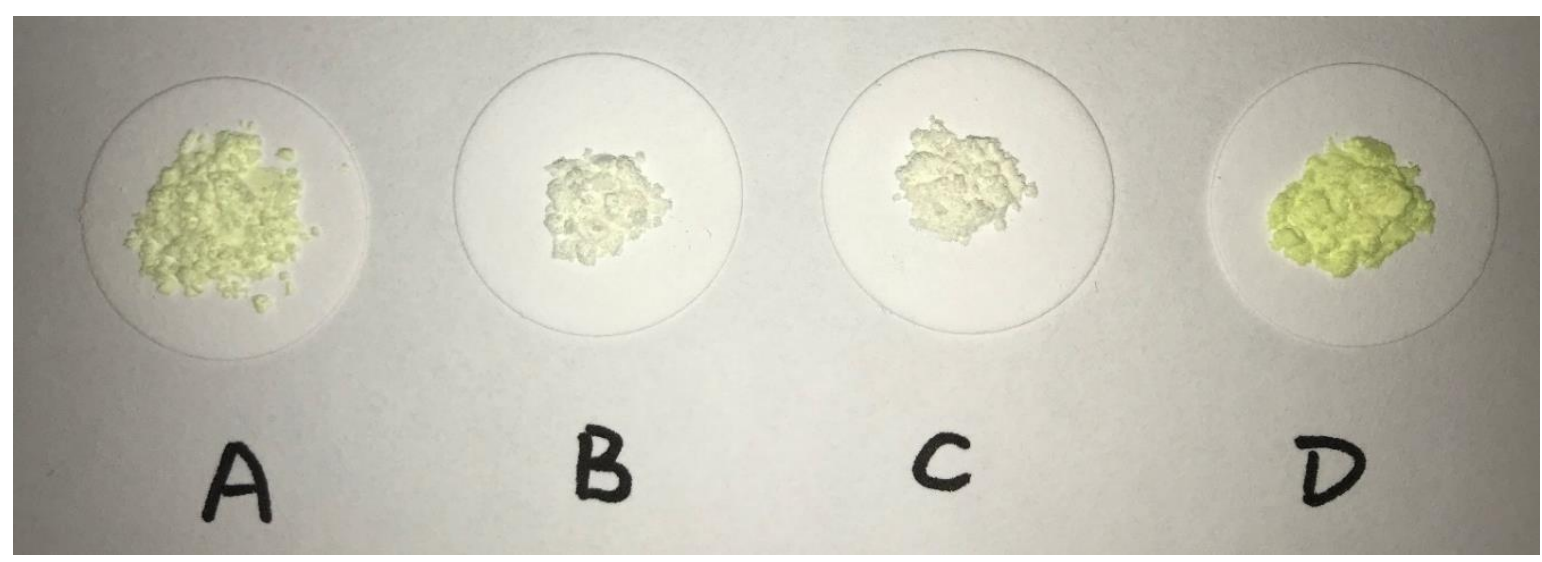

Figure S 1. Appearance of Molecule XXIII Form A, Form B, Form C and Form D 
Five Degrees of Separation: Characterization and Temperature Stability Profiles for the Polymorphs of PD-0118057 (Molecule XXIII)- Supporting Information

\section{${ }^{1} \mathrm{H}$ and ${ }^{13} \mathrm{C}$ NMR SPECTROSCOPY}

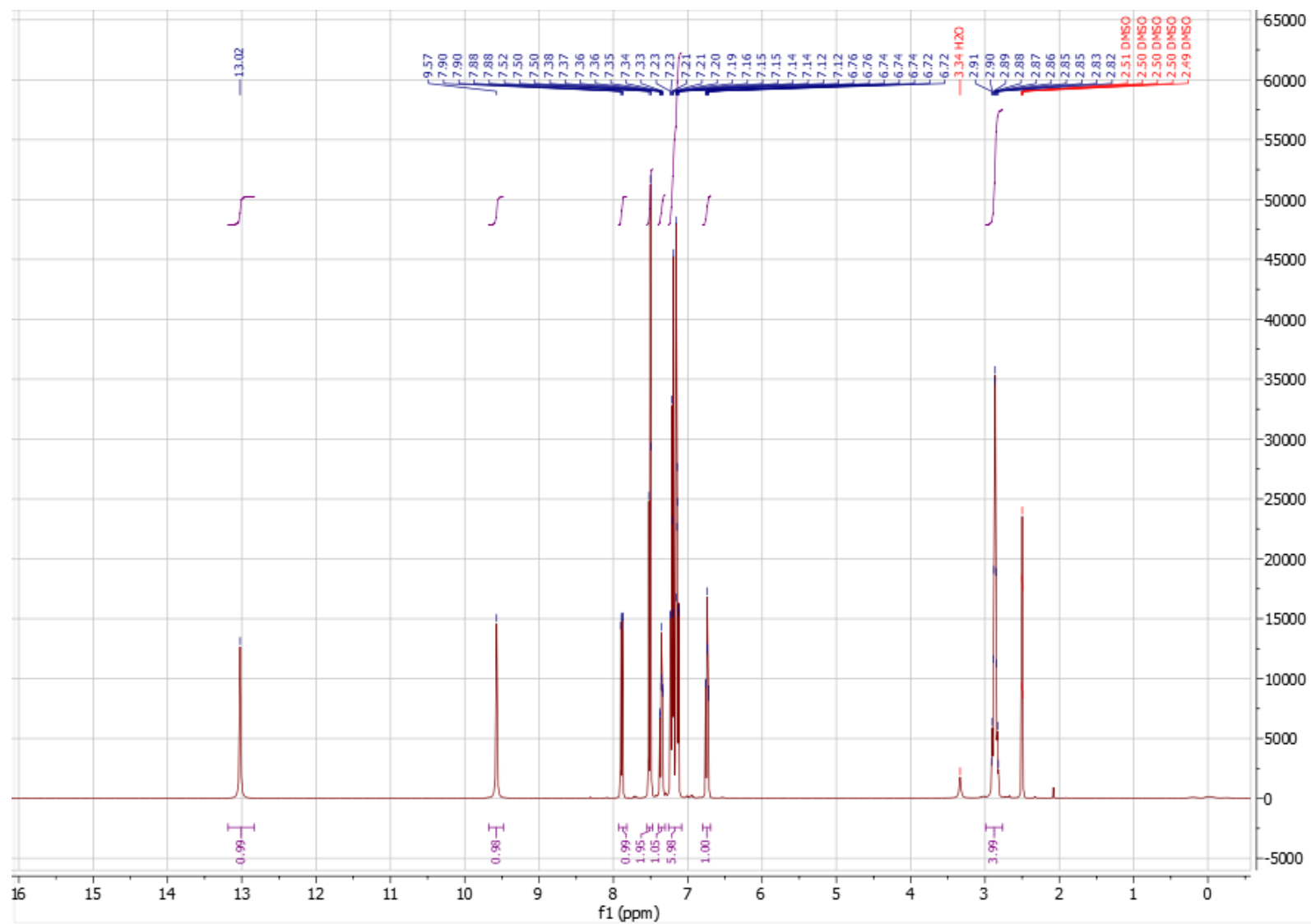

Figure S 2. ${ }^{1} \mathrm{H}$ NMR spectrum of Molecule XXIII. DMSO-d6, $400 \mathrm{MHz}$. 


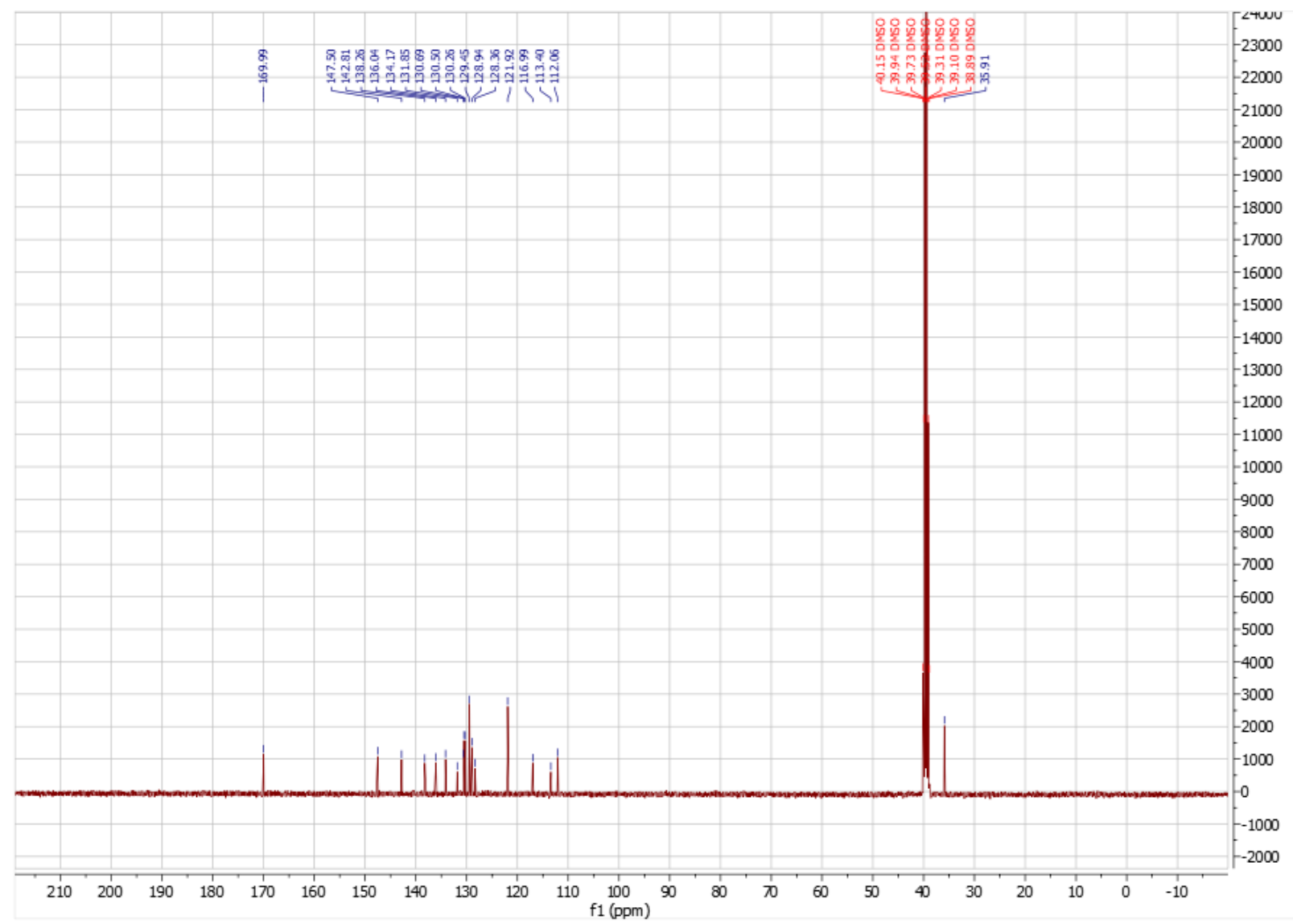

Figure S 3. ${ }^{13} \mathrm{C}$ NMR spectrum of Molecule XXIII. DMSO- $d_{6}, 101 \mathrm{MHz}$.

${ }^{1} \mathrm{H}$ NMR (400 MHz, DMSO- $\left.d_{6}\right): \delta 13.02(\mathrm{~s}, 1 \mathrm{H}), 9.57(\mathrm{~s}, 1 \mathrm{H}), 7.89(\mathrm{dd}, J=8.0,1.7 \mathrm{~Hz}, 1 \mathrm{H}), 7.55-$ 7.47 (m, 2H), 7.36 (ddd, $J=8.7,7.1,1.8 \mathrm{~Hz}, 1 \mathrm{H}), 7.26-7.08(\mathrm{~m}, 6 \mathrm{H}), 6.74$ (ddd, $J=8.1,7.1,1.1 \mathrm{~Hz}$, 1H), 2.87 (h, $J=3.0 \mathrm{~Hz}, 4 \mathrm{H}$ );

${ }^{13} \mathrm{C}$ NMR (101 MHz, DMSO-d $)$ ): $\delta 169.99,147.50,142.81,138.26,136.04,134.17,131.85,130.69$, $130.50,130.26,129.45,128.94,128.36,121.92,116.99,113.40,112.06,35.92$. 


\section{INSTRUMENTATION}

\section{Powder X-ray Diffraction}

Powder X-ray diffraction analysis was conducted using a Bruker AXS D8 Endeavor diffractometer equipped with a $\mathrm{Cu}$ radiation source. The divergence slit was set at $10 \mathrm{~mm}$ continuous illumination. Diffracted radiation was detected by a PSD-Lynx Eye detector, with the detector PSD opening set at 2.99 degrees. The X-ray tube voltage and amperage were set to $40 \mathrm{kV}$ and $40 \mathrm{~mA}$ respectively. Data was collected in the Theta-Theta goniometer at the $\mathrm{Cu}$ wavelength from 3.0 to 40.0 degrees 2-Theta using a step size of 0.02 degrees and a step time of 0.3 second. The antiscatter screen was set to a fixed distance of $1.5 \mathrm{~mm}$. Samples were rotated at 15/min during collection. Samples were prepared by placing them in a silicon low background sample holder and rotated during collection. Data were collected using Bruker DIFFRAC Plus software and analysis was performed by EVA diffract plus software.

\section{Thermogravimetric Analysis (TGA)}

Thermogravimetric analysis was conducted using a Discovery TGA (TA instruments) thermogravimetric analyzer. Samples of approximately $10 \mathrm{mg}$ were weighed into aluminum pans and heated from ambient to $300{ }^{\circ} \mathrm{C}$ at $10{ }^{\circ} \mathrm{C} /$ minute heating rate under nitrogen purge $(10 \mathrm{~mL} / \mathrm{min}$ for both sample chamber and balance).

\section{Differential Scanning Calorimetry (DSC)}

DSC measurements were performed with Discovery DSC (TA instruments) equipped with a refrigerated cooling accessory. All the experiments were performed in standard/Tzero aluminum pans. The cell constant was determined using indium and temperature calibration was performed using indium and tin as standards. All the measurements were done under continuous dry nitrogen purge $(50 \mathrm{~mL} / \mathrm{min})$. Approximately $1-5 \mathrm{mg}$ of solid sample was weighed into a Tzero aluminum pan, sealed non-hermetically and heated from ambient to 250 or $275^{\circ} \mathrm{C}$ at $10^{\circ} \mathrm{C} / \mathrm{min}$ heating rate. The experimental data were analyzed using commercially available software (TA Universal Analysis 2000/Trios software, TA Instruments). 


\section{SOLUBILITY DETERMINATION}

\section{General Procedure}

Molecule XXIII was suspended in solvents for 15 days at room temperature. The slurried solids were collected and an aliquot $(200 \mu \mathrm{L})$ of the filtrate was evaporated with gentle warming $\left(55^{\circ} \mathrm{C}\right)$. The solubility was determined gravimetrically based on the weight of the solid residue remaining afterdrying. The collected solid's powder X-ray diffractogram patterns were a match to Form D.

\section{Solubility Data}

Table S 2. Solubility data for Molecule XXIII Form D.

\begin{tabular}{|c|c|c|}
\hline Entry & Solvent & Solubility $(\mathrm{mg} / \mathrm{mL})$ \\
\hline 1 & Acetone & 67 \\
\hline 2 & EtOAc & 47 \\
\hline 3 & MeOH & 8 \\
\hline 4 & hexanes & 3 \\
\hline 5 & Isopropanol & 8 \\
\hline 6 & MTBE & $>20$ \\
\hline 7 & DCM & 19 \\
\hline 8 & THF & $>60$ \\
\hline 9 & EtOH & 14 \\
\hline 10 & $2-$ methyl THF & $>50$ \\
\hline 11 & Cyclohexane & 2 \\
\hline 12 & water & $<0.1$ \\
\hline 13 & acetonitrile & 8 \\
\hline 14 & Dioxane & $>30$ \\
\hline 15 & Toluene & 7 \\
\hline
\end{tabular}




\section{POWDER X-RAY DIFFRACTION PATTERNS}

\section{Calculated PXRD Patterns}

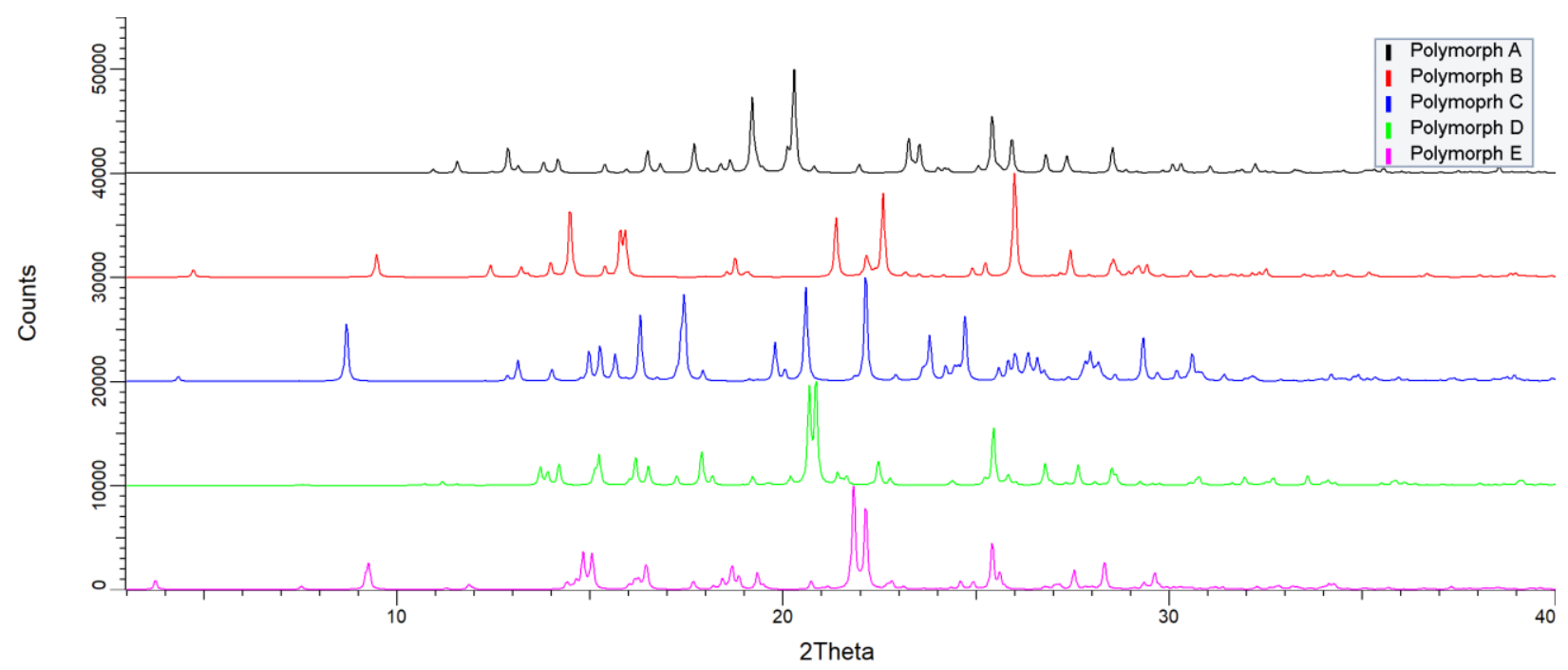

Figure S 4. Calculated Powder X-ray diffractograms of Forms A, B, C, D and E (from top to bottom). 
Five Degrees of Separation: Characterization and Temperature Stability Profiles for the Polymorphs of PD-0118057 (Molecule XXIII)- Supporting Information

\section{THERMAL ANALYSIS}

Thermogravimetric Analysis (TGA)

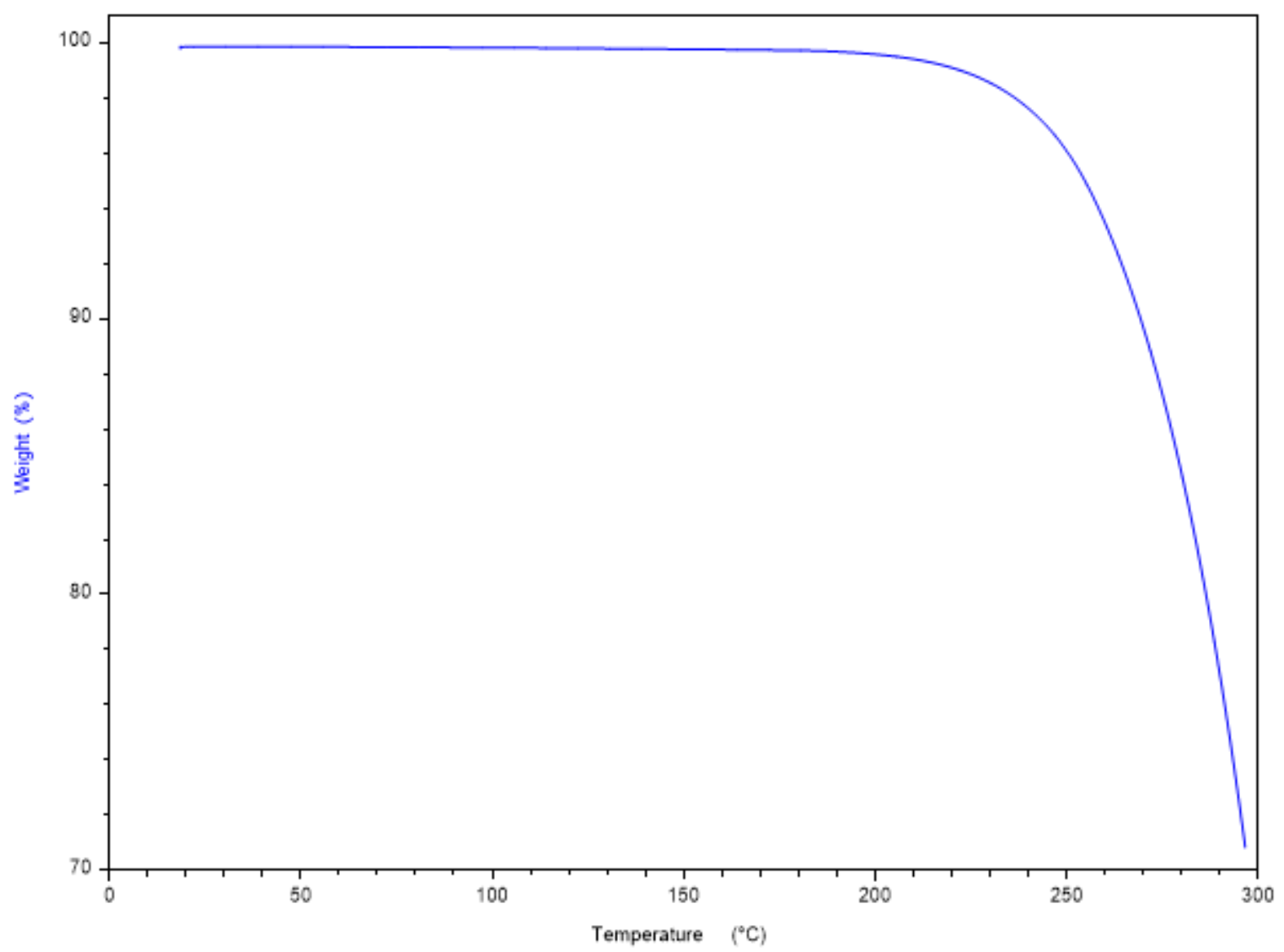

Figure S 5. TGA of Molecule XXIII Form A 
Five Degrees of Separation: Characterization and Temperature Stability Profiles for the Polymorphs of PD-0118057 (Molecule XXIII)- Supporting Information

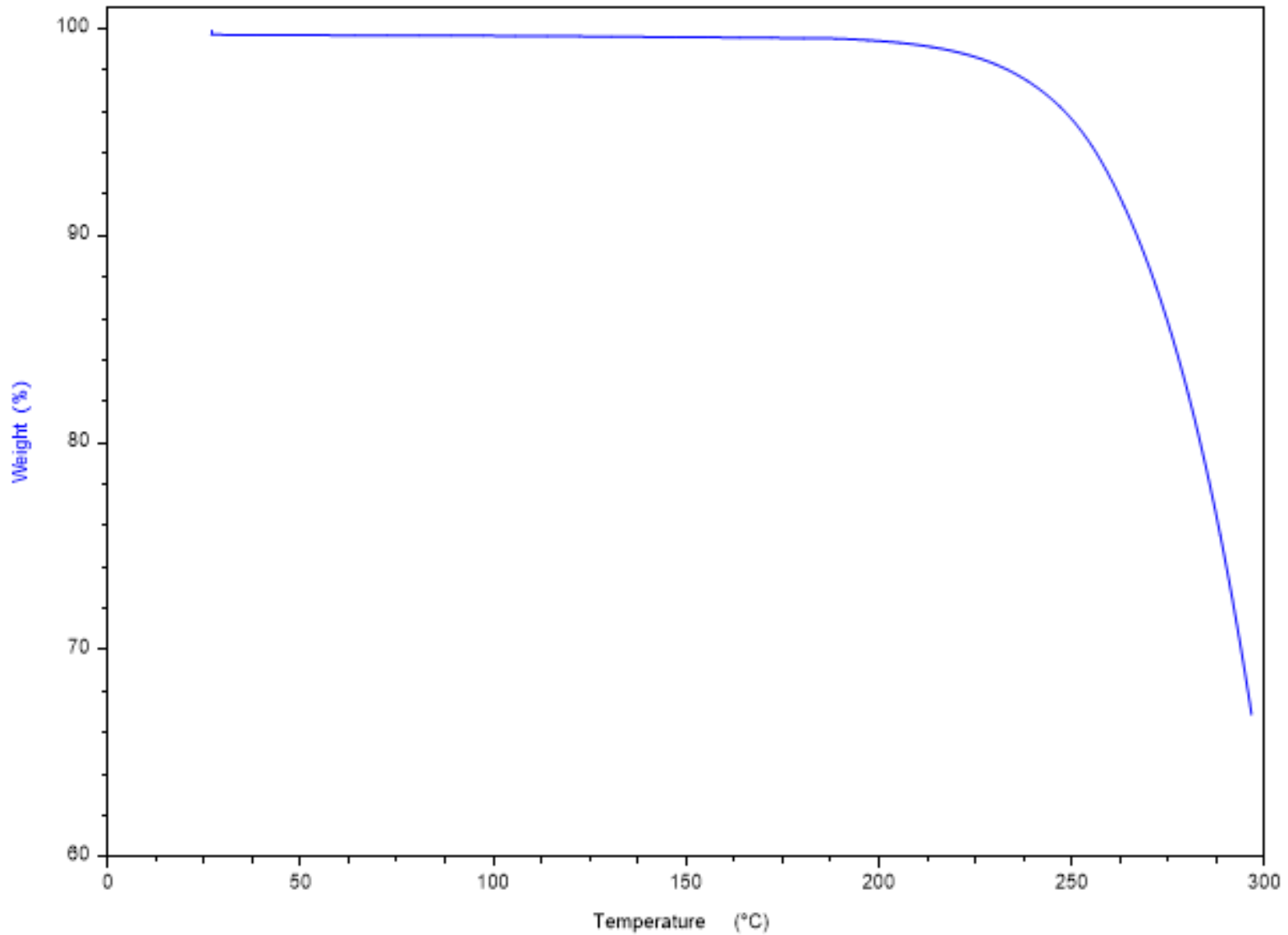

Figure S 6. TGA of Molecule XXIII Form B 
Five Degrees of Separation: Characterization and Temperature Stability Profiles for the Polymorphs of PD-0118057 (Molecule XXIII)- Supporting Information

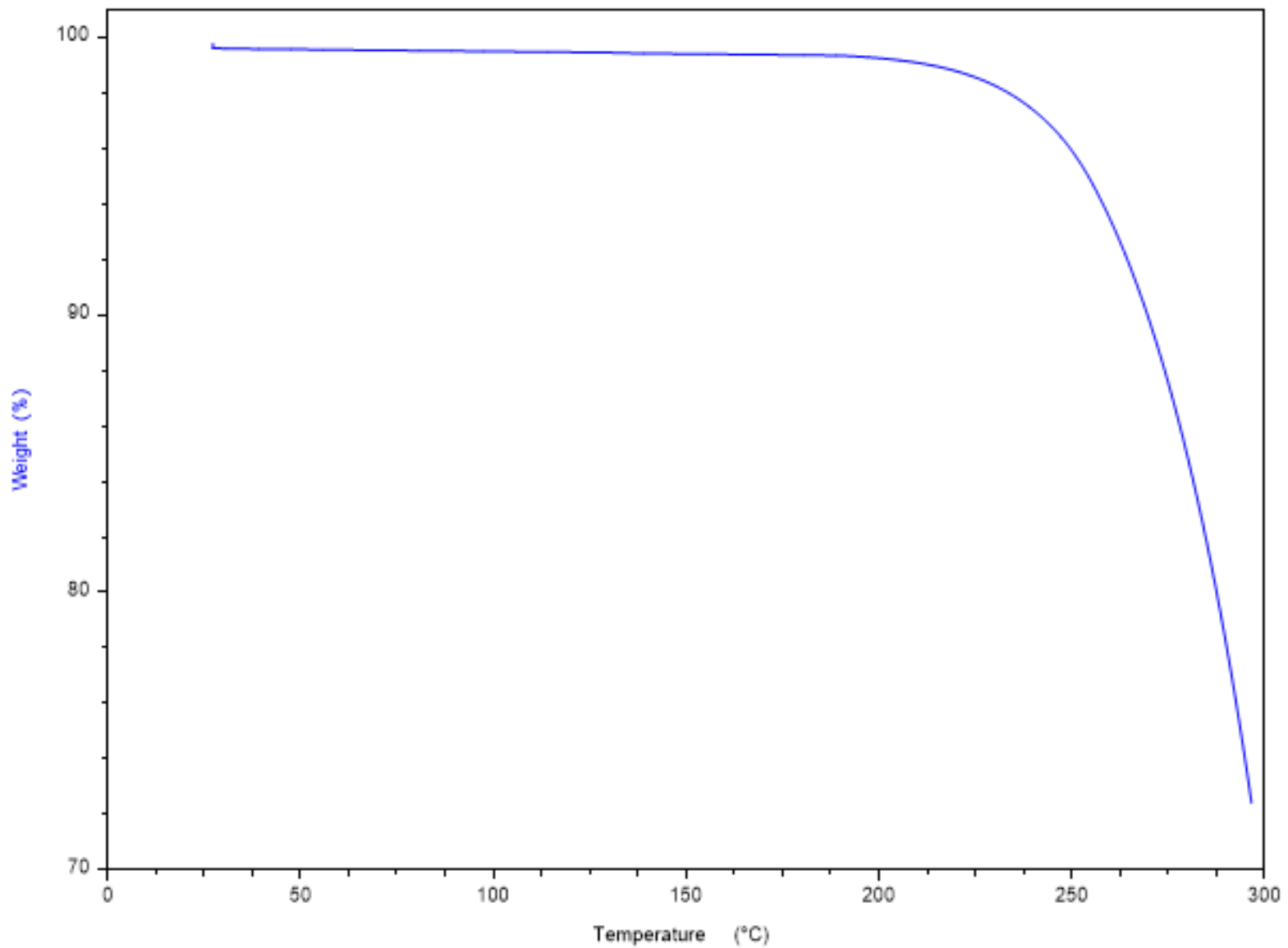

Figure S 7. TGA of Molecule XXIII Form C 
Five Degrees of Separation: Characterization and Temperature Stability Profiles for the Polymorphs of PD-0118057 (Molecule XXIII)- Supporting Information

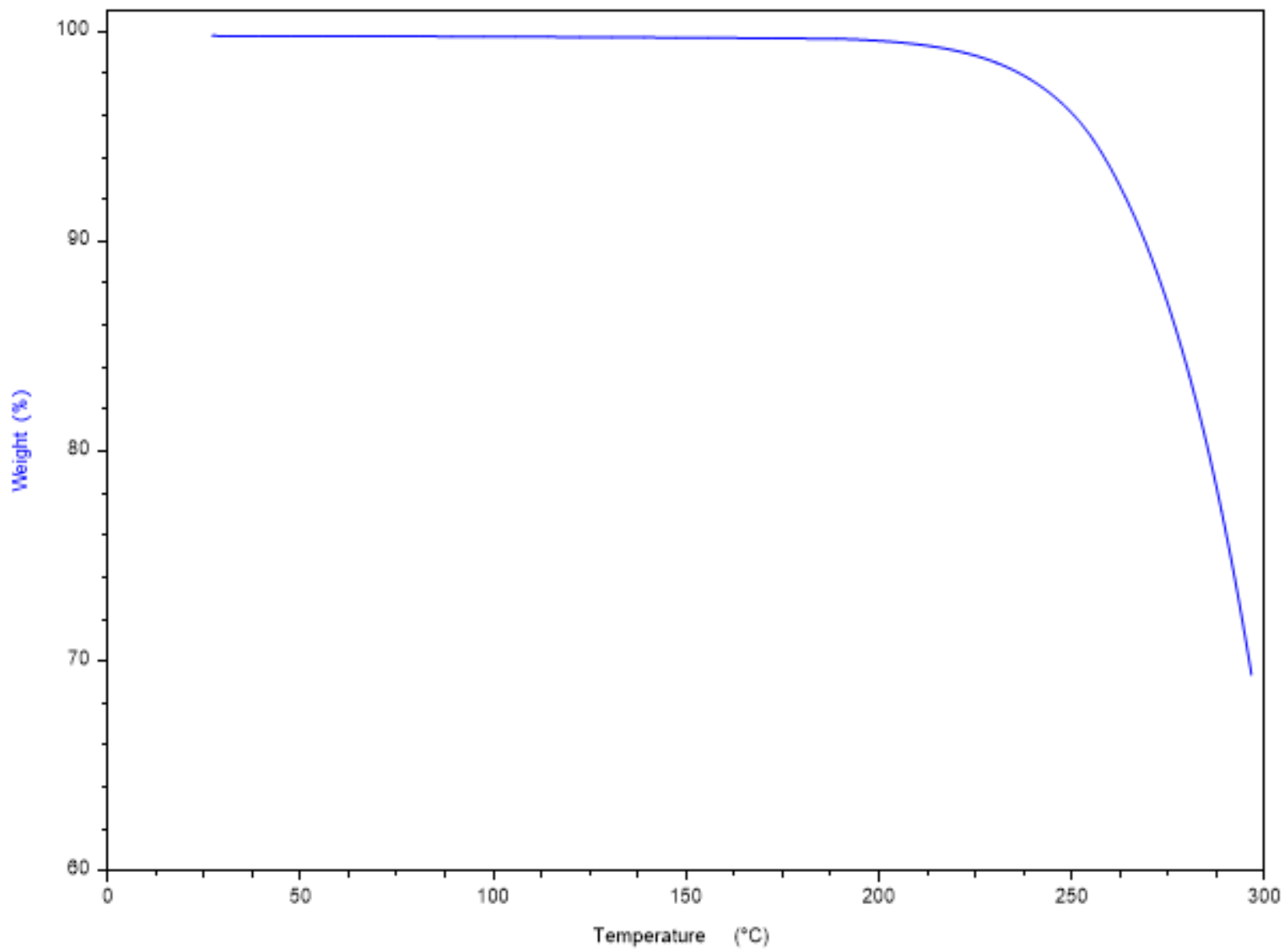

Figure S 8. TGA of Molecule XXIII Form D 
Five Degrees of Separation: Characterization and Temperature Stability Profiles for the Polymorphs of PD-0118057 (Molecule XXIII)- Supporting Information

\section{Differential Scanning Calorimetry (DSC)}

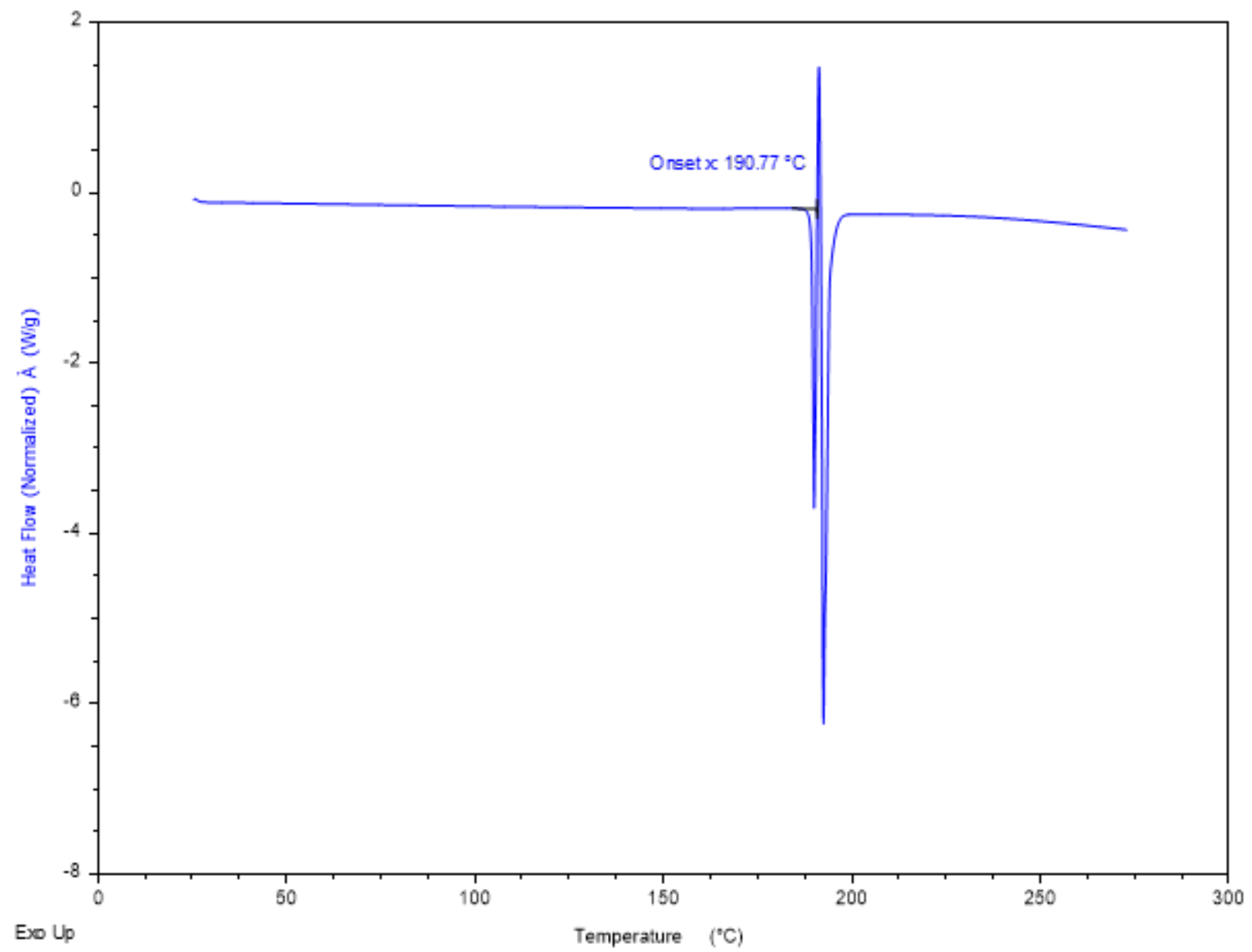

Figure S 9. DSC of Molecule XXIII Form A 
Five Degrees of Separation: Characterization and Temperature Stability Profiles for the Polymorphs of PD-0118057 (Molecule XXIII)- Supporting Information

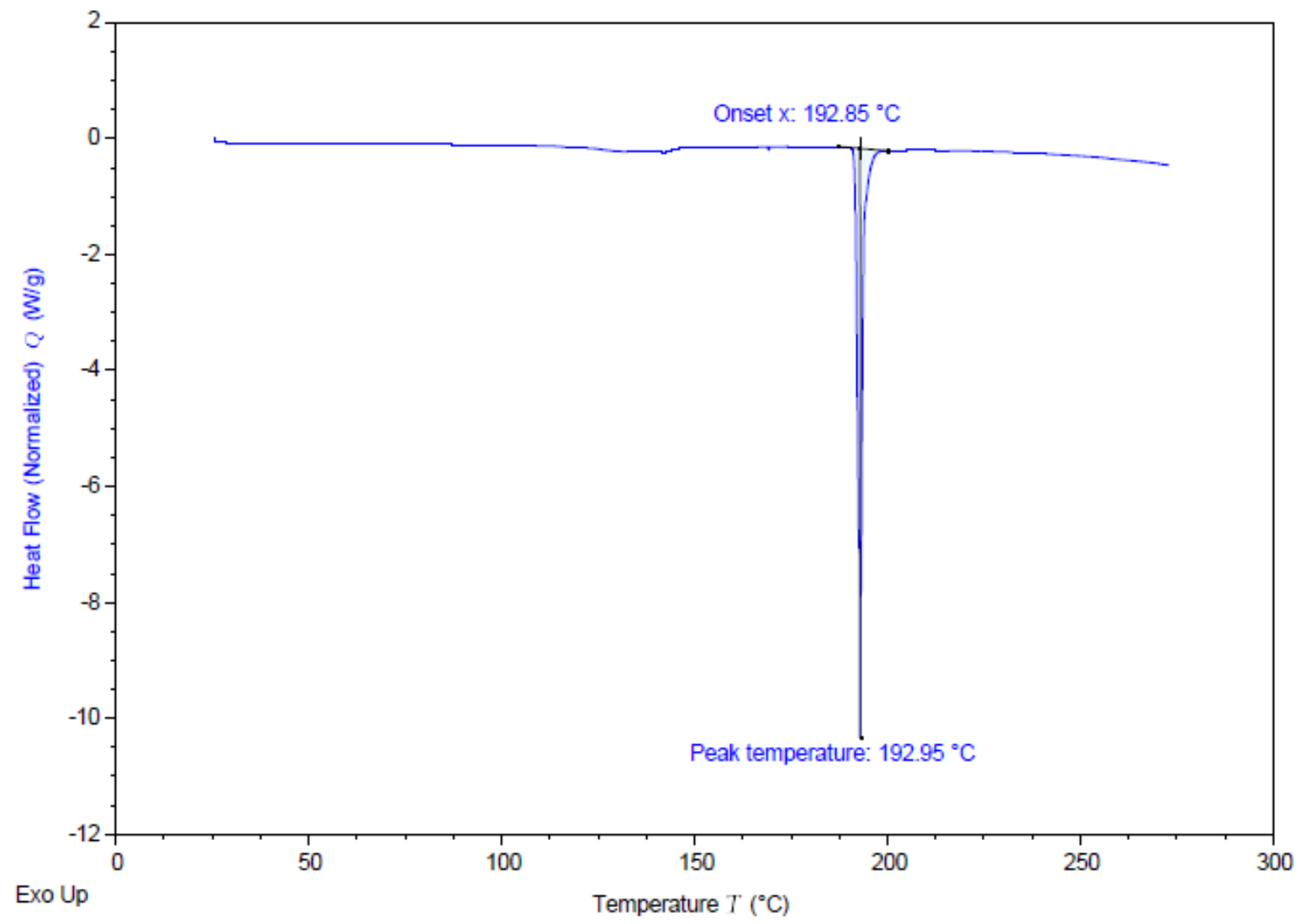

Figure S 10. DSC of Molecule XXIII Form B 
Five Degrees of Separation: Characterization and Temperature Stability Profiles for the Polymorphs of PD-0118057 (Molecule XXIII)- Supporting Information

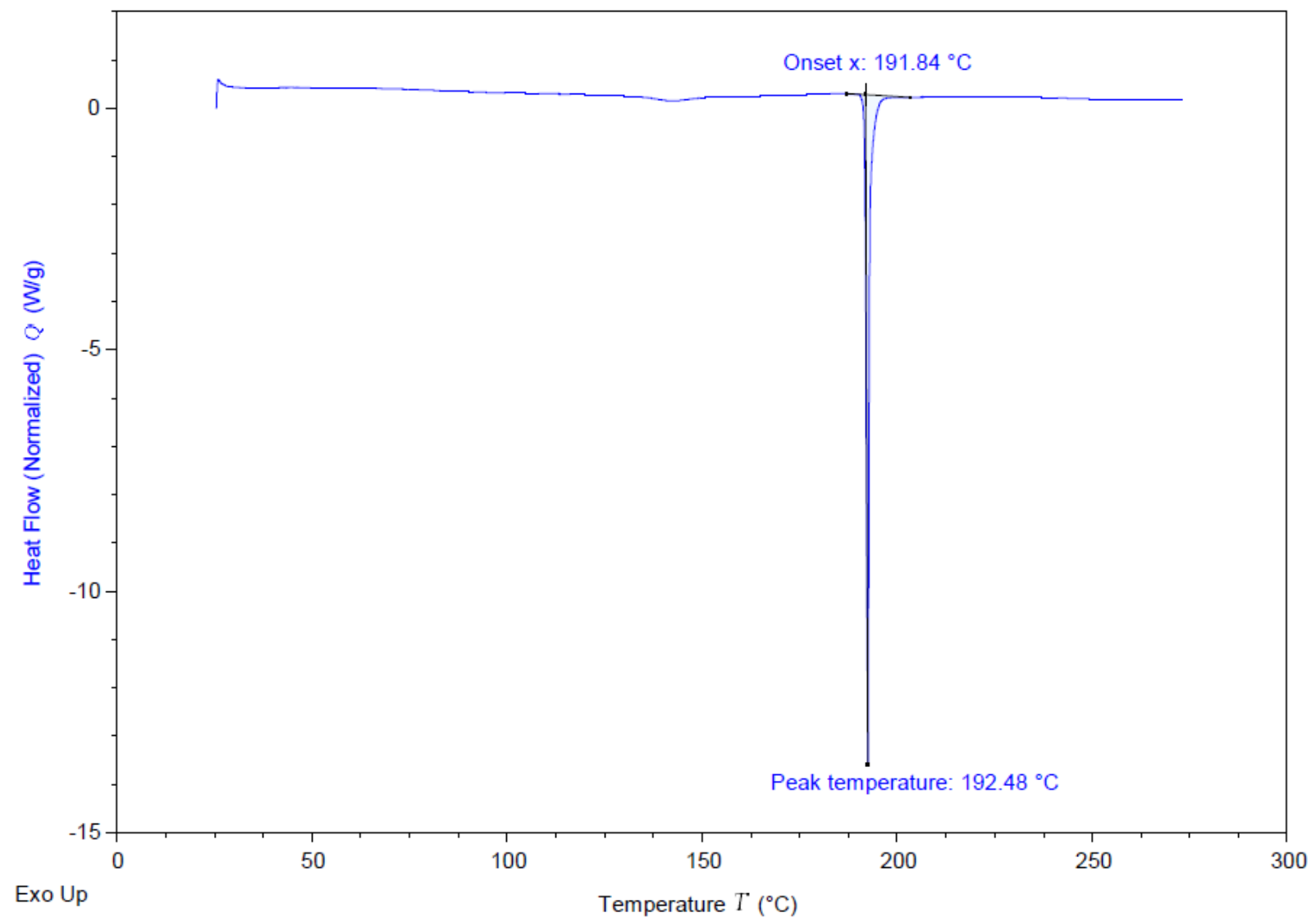

Figure S 11. DSC of Molecule XXIII Form C 
Five Degrees of Separation: Characterization and Temperature Stability Profiles for the Polymorphs of PD-0118057 (Molecule XXIII)- Supporting Information

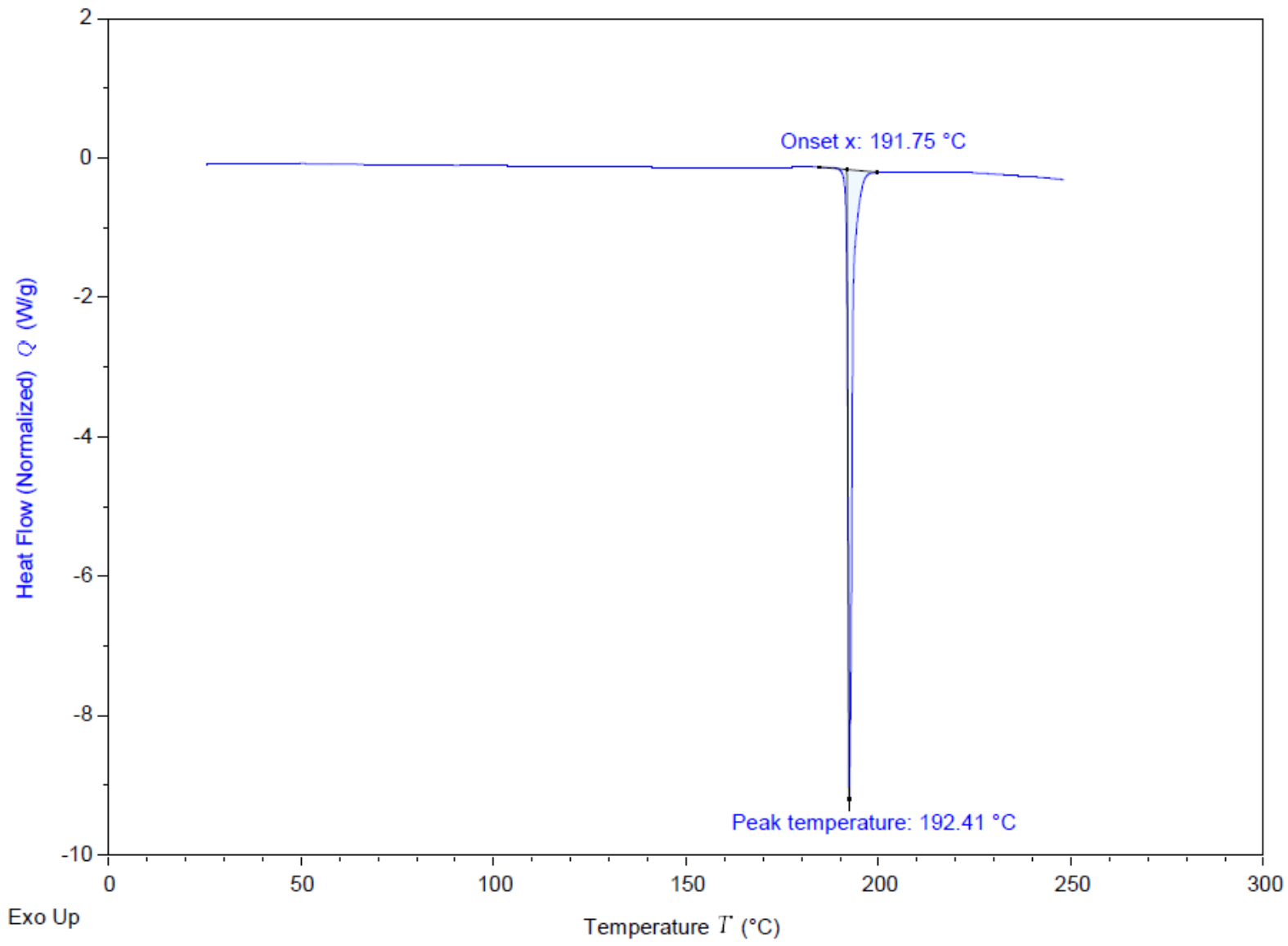

Figure S 12. DSC of Molecule XXIII Form D 


\section{Thermal Transition of Form A}

Approximately 5-10 mg of solid sample was weighed into a Tzero aluminum pan, sealed nonhermetically and heated from ambient to $189.5{ }^{\circ} \mathrm{C}$ at $1{ }^{\circ} \mathrm{C} / \mathrm{min}$ heating rate, hold for 12 seconds, then ramp back to $20^{\circ} \mathrm{C}$. The solid sample was collected and analyzed by powder X-ray diffraction.

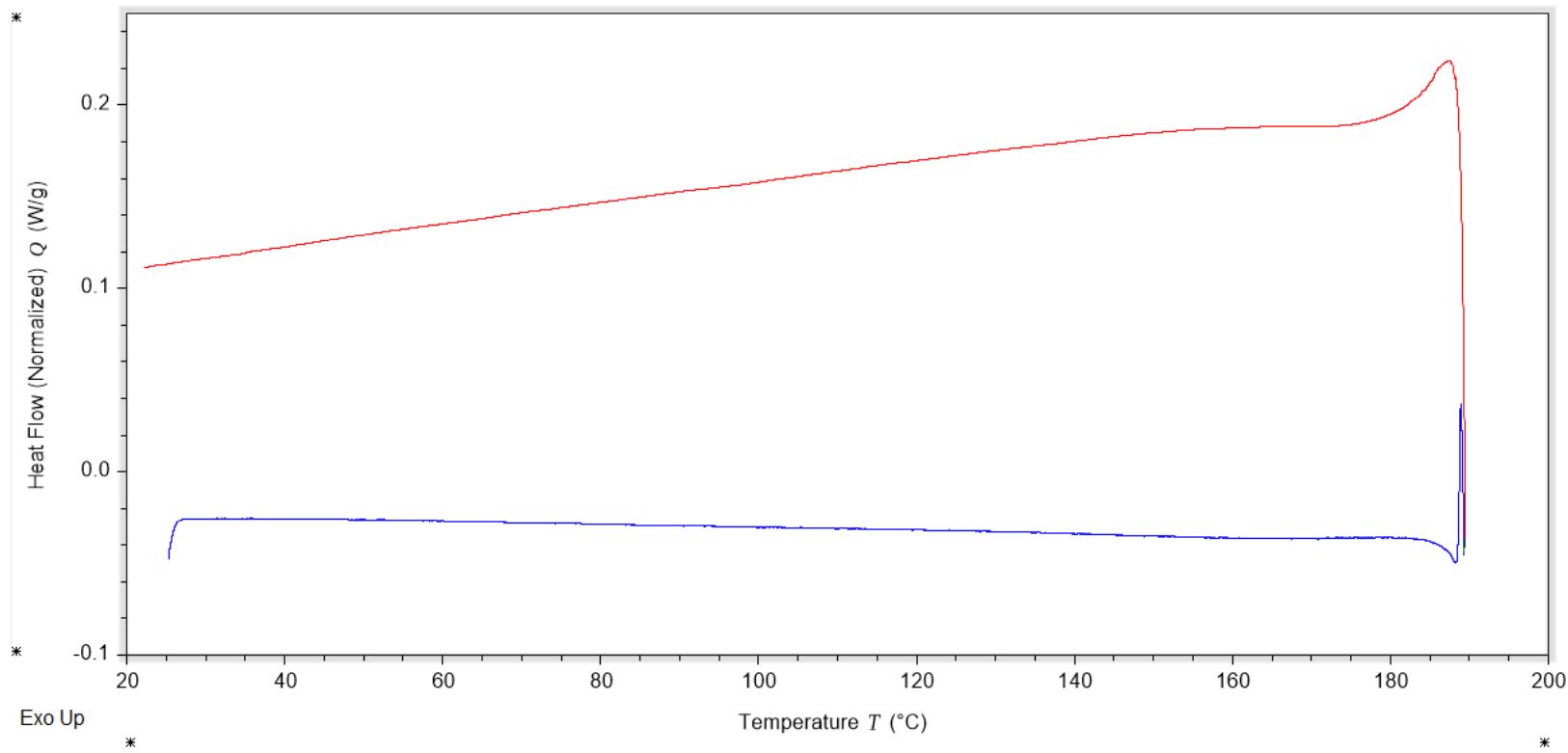

Figure S 13. DSC scan of Molecule XXIII Form A (heated from ambient to $189.5{ }^{\circ} \mathrm{C}$ at $1{ }^{\circ} \mathrm{C} / \mathrm{min}$ heating rate, hold for 12 seconds, then ramp back to $20^{\circ} \mathrm{C}$ )

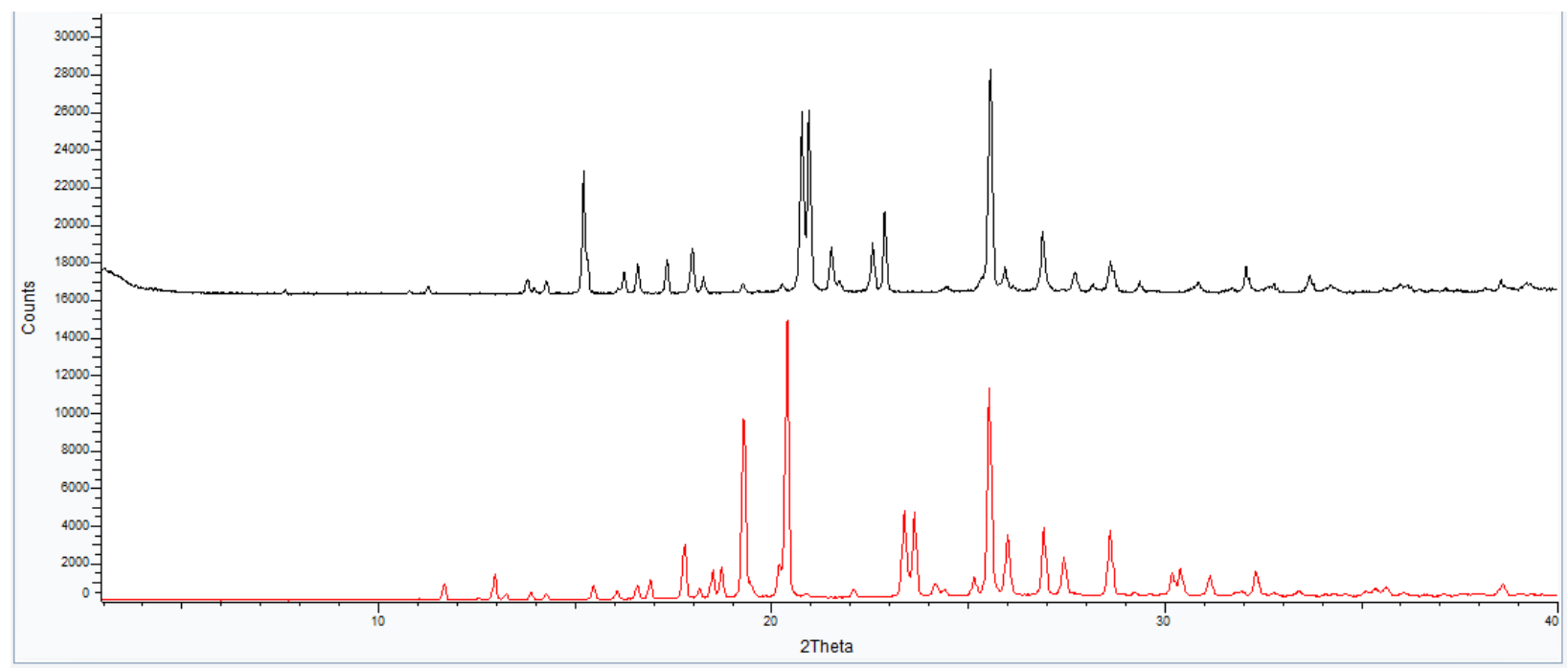

Figure S 14. Overlay the powder X-ray diffractogram showing Form A was converted to Form D. Form A (bottom, ingoing), Form D (top, Form A was heated from ambient to $189.5^{\circ} \mathrm{C}$ at $1{ }^{\circ} \mathrm{C} / \mathrm{min}$ heating rate, hold for 12 seconds, then ramp back to $20^{\circ} \mathrm{C}$ ) 


\section{Solid to Solid Transitions of Form B and Form C}

Approximately 5-10 mg of solid sample was weighed into a Tzero aluminum pan, sealed nonhermetically and heated from ambient to $160^{\circ} \mathrm{C}$ at $10^{\circ} \mathrm{C} / \mathrm{min}$ heating rate, hold for 12 seconds, then ramp back to $25^{\circ} \mathrm{C}$. The solid sample was collected and analyzed by powder X-ray diffraction.

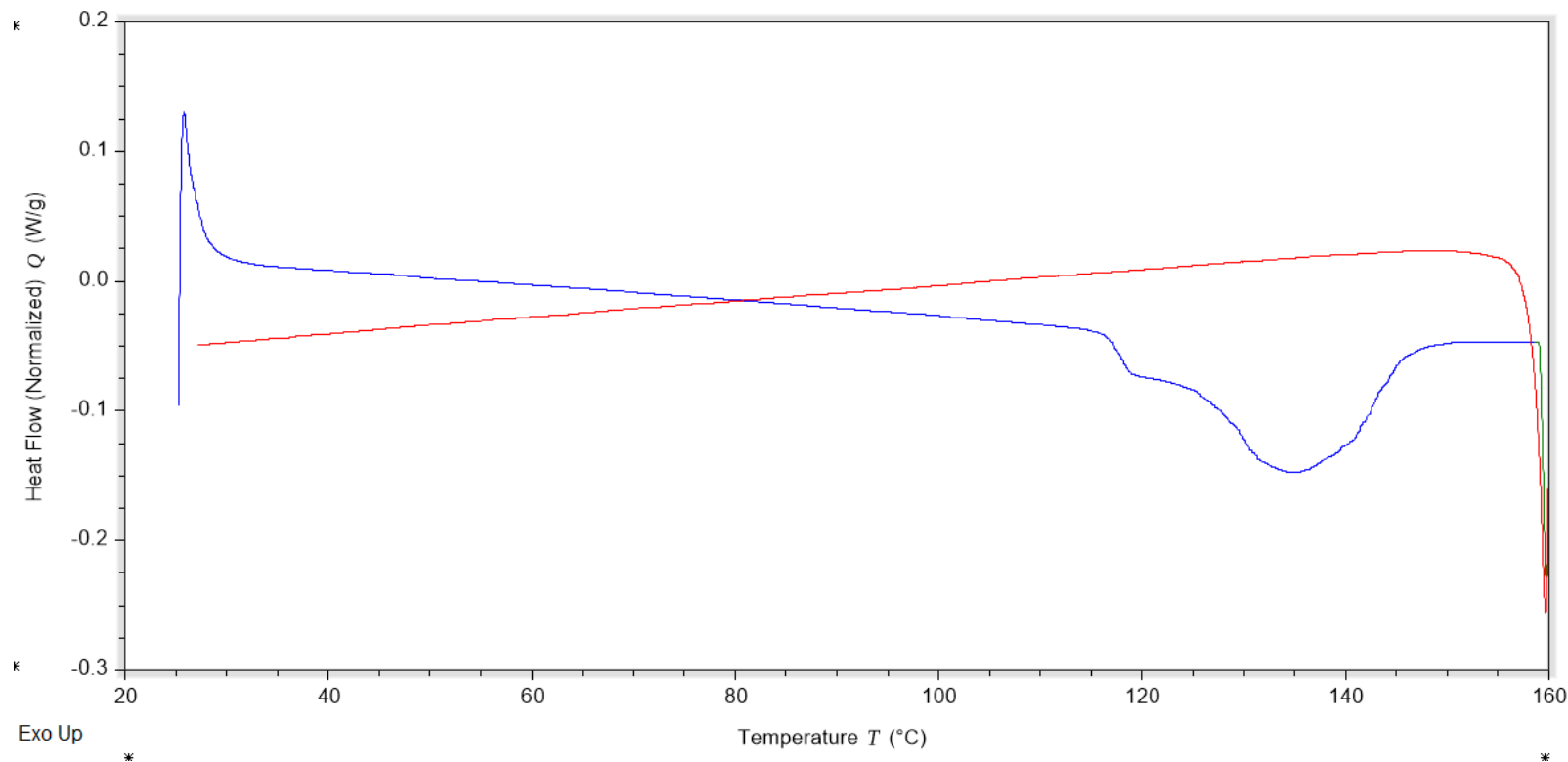

Figure S 15. DSC of Molecule XXIII Form B (heated from ambient to $160{ }^{\circ} \mathrm{C}$ at $10^{\circ} \mathrm{C} / \mathrm{min}$ heating rate, hold for 12 seconds, then ramp back to $25^{\circ} \mathrm{C}$ )

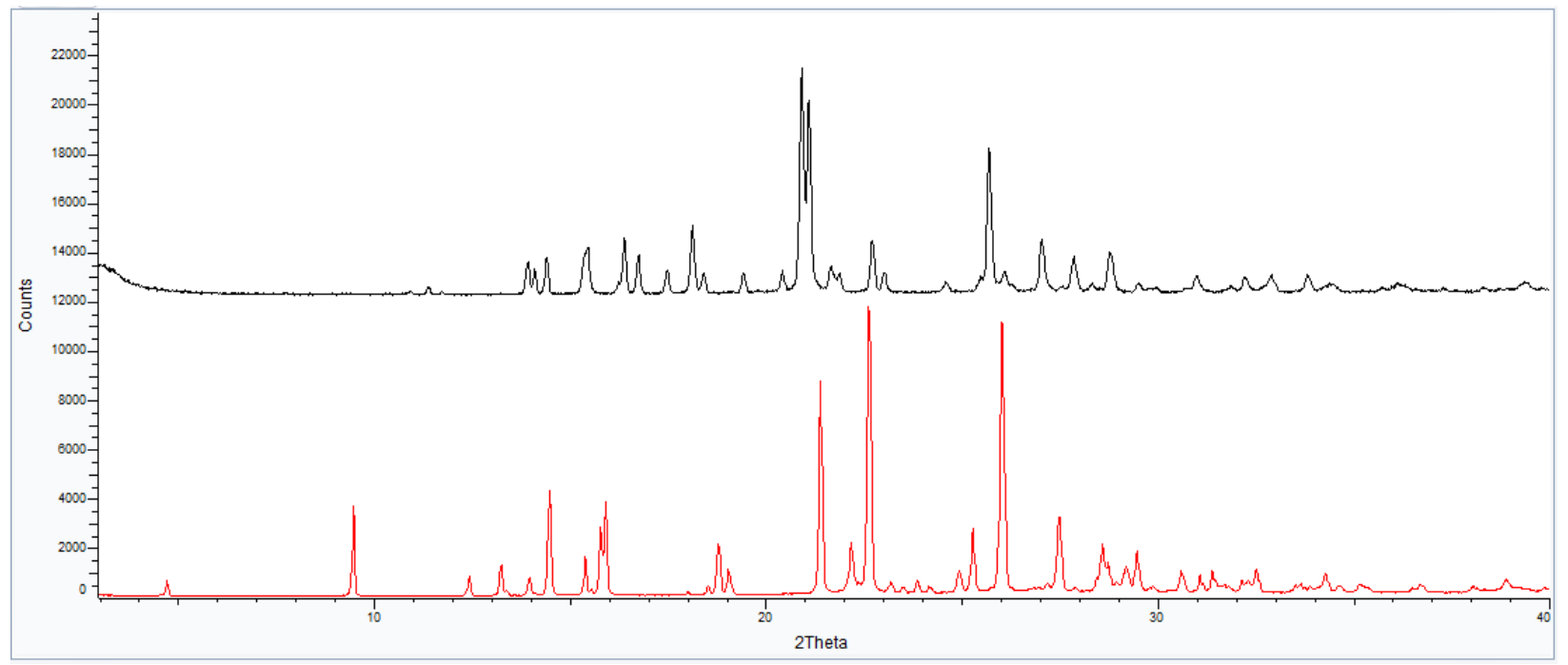

Figure S 16. Overlay the powder X-ray diffractogram showing Form B was converted to Form D. Form $\mathrm{B}$ (bottom, ingoing), Form $\mathrm{D}$ (top, Form $\mathrm{B}$ was heated from ambient to $160{ }^{\circ} \mathrm{C}$ at $10^{\circ} \mathrm{C} / \mathrm{min}$ heating rate, hold for 12 seconds, then ramp back to $25^{\circ} \mathrm{C}$ ) 
Five Degrees of Separation: Characterization and Temperature Stability Profiles for the Polymorphs of PD-0118057 (Molecule XXIII)- Supporting Information

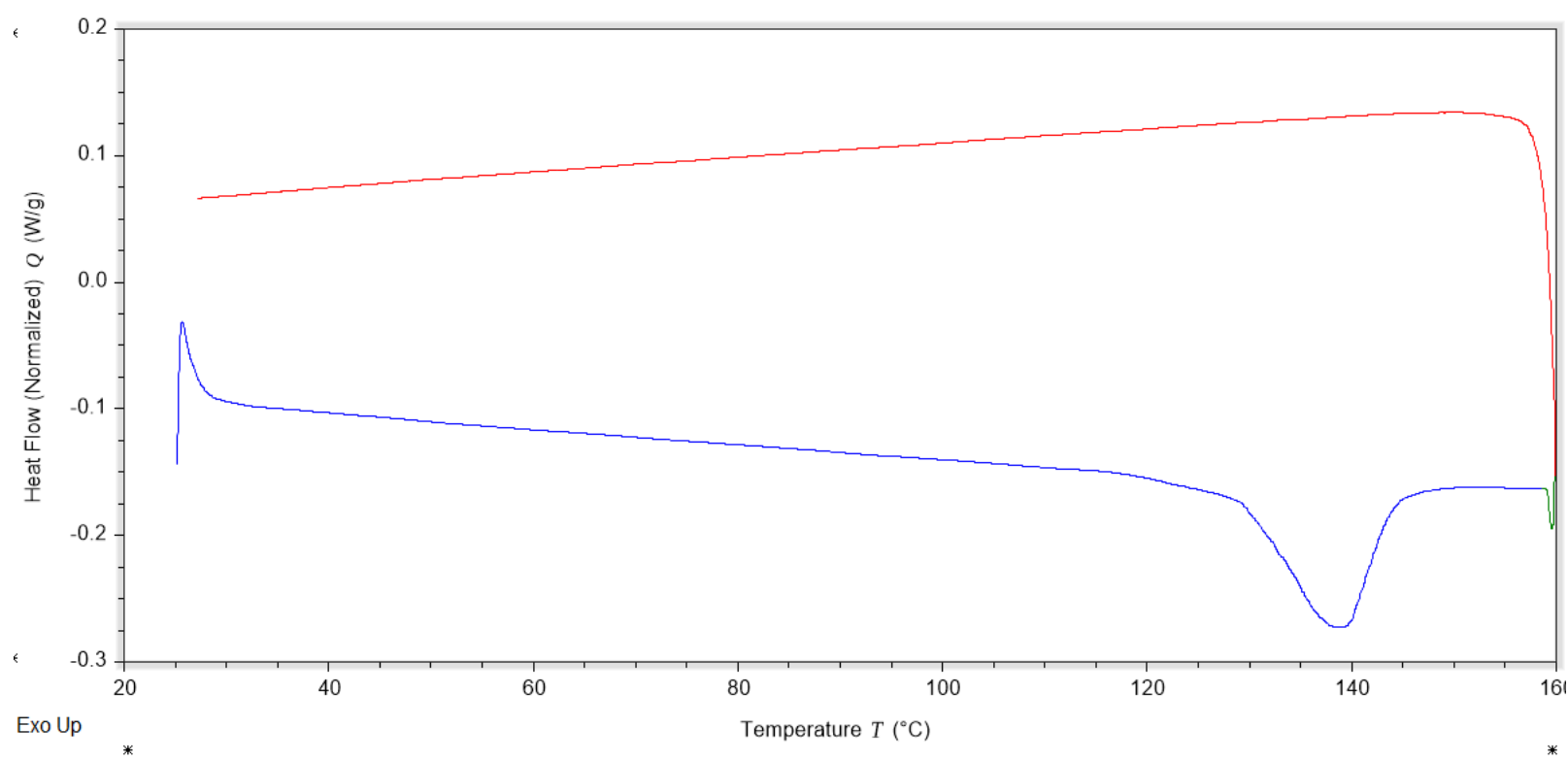

Figure S 17. DSC of Molecule XXIII Form C (heated from ambient to $160{ }^{\circ} \mathrm{C}$ at $10^{\circ} \mathrm{C} / \mathrm{min}$ heating rate, hold for 12 seconds, then ramp back to $25^{\circ} \mathrm{C}$ )

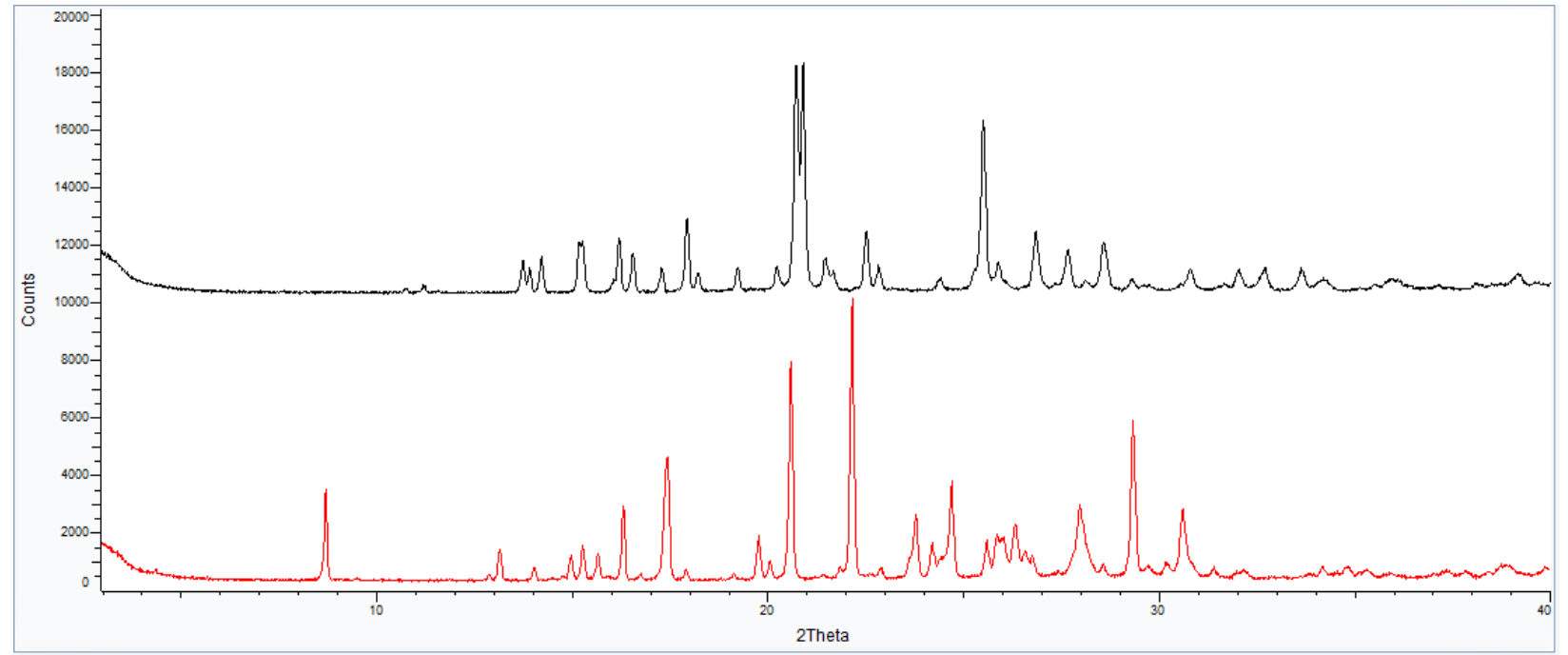

Figure S 18. Overlay the powder X-ray diffractogram showing Form $\mathrm{C}$ was converted to Form D. Form $\mathrm{C}$ (bottom, ingoing), Form $\mathrm{D}$ (top, Form $\mathrm{C}$ was heated from ambient to $160{ }^{\circ} \mathrm{C}$ at $10^{\circ} \mathrm{C} / \mathrm{min}$ heating rate, hold for 12 seconds, then ramp back to $25^{\circ} \mathrm{C}$ ) 
Variable Temperature PXRD of Form C

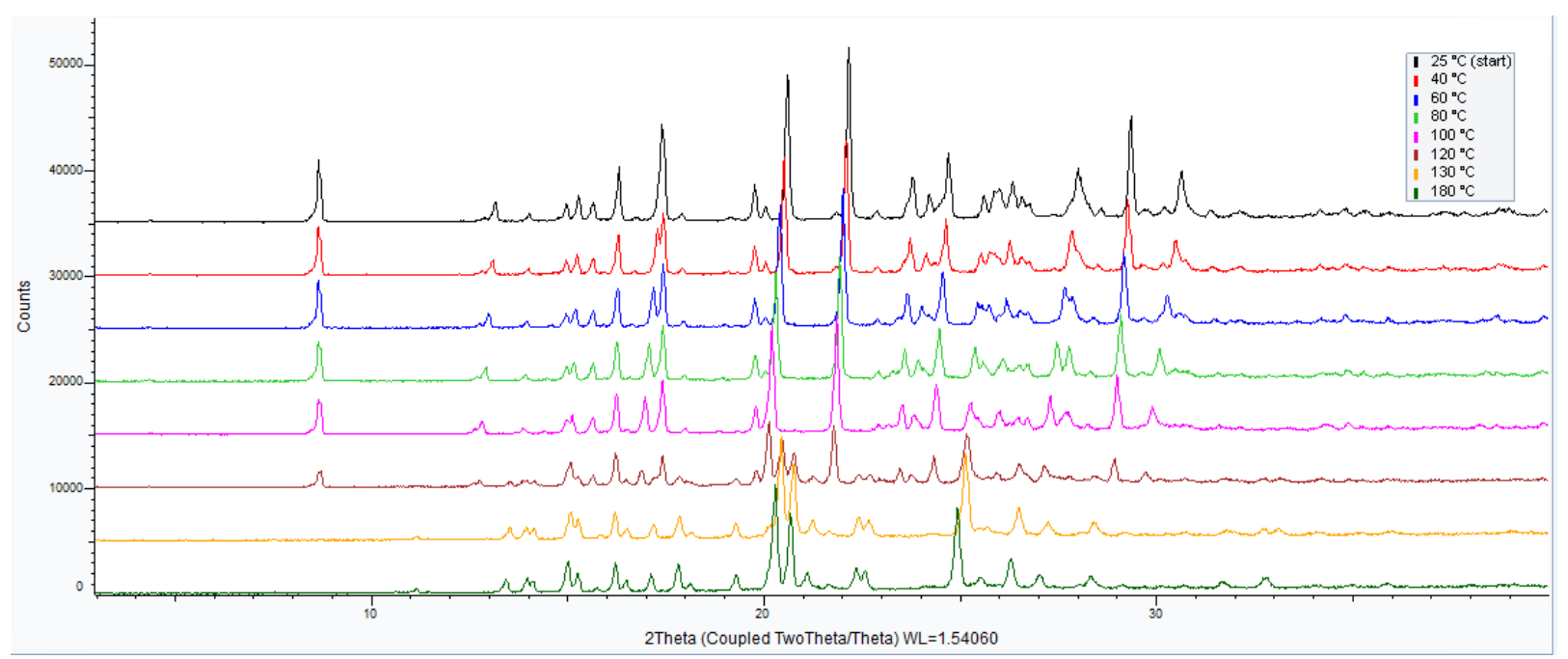

Figure S 19. Variable temperature powder X-ray diffractogram of Form C (select temperatures shown). Note the form change observed at $120-130^{\circ} \mathrm{C}$. 


\section{INDEXED CRYSTALS}

Crystal images are shown below of indexed Forms A-D. In each case, the real space axes are overlaid on the images. Form D crystals were difficult to separate and what is shown is a fragment of the crystal which is broken off.

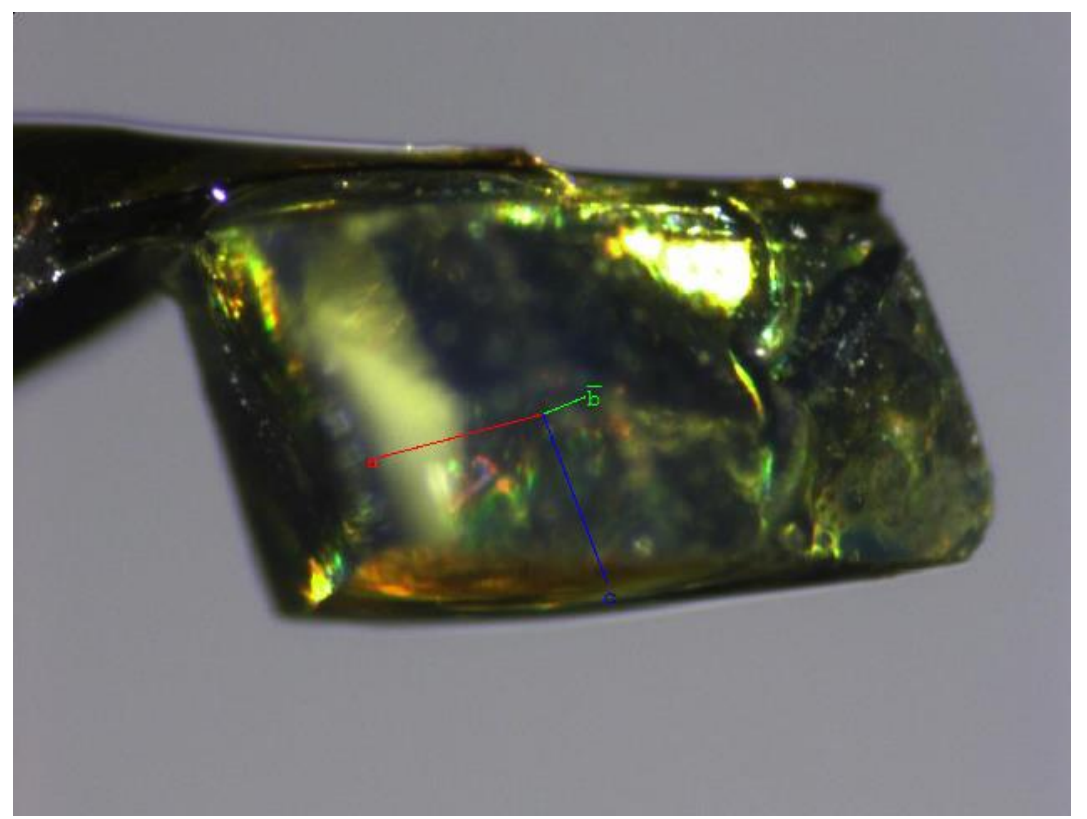

Figure S 20. Form A

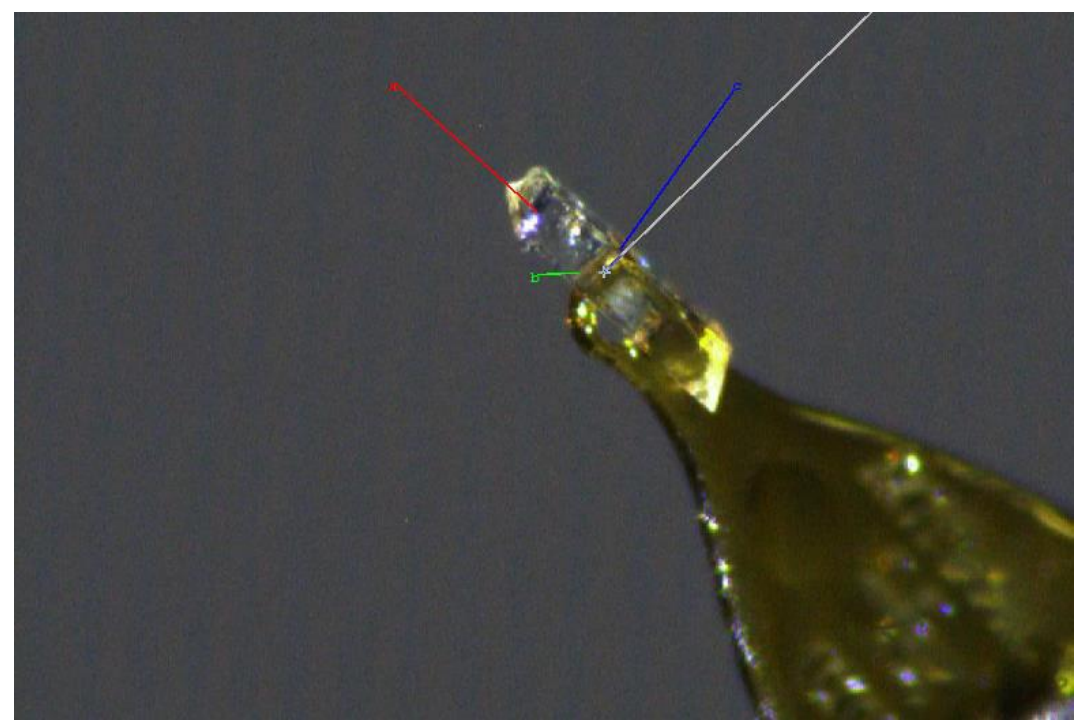

Figure S 21. Form B 
Five Degrees of Separation: Characterization and Temperature Stability Profiles for the Polymorphs of PD-0118057 (Molecule XXIII)- Supporting Information

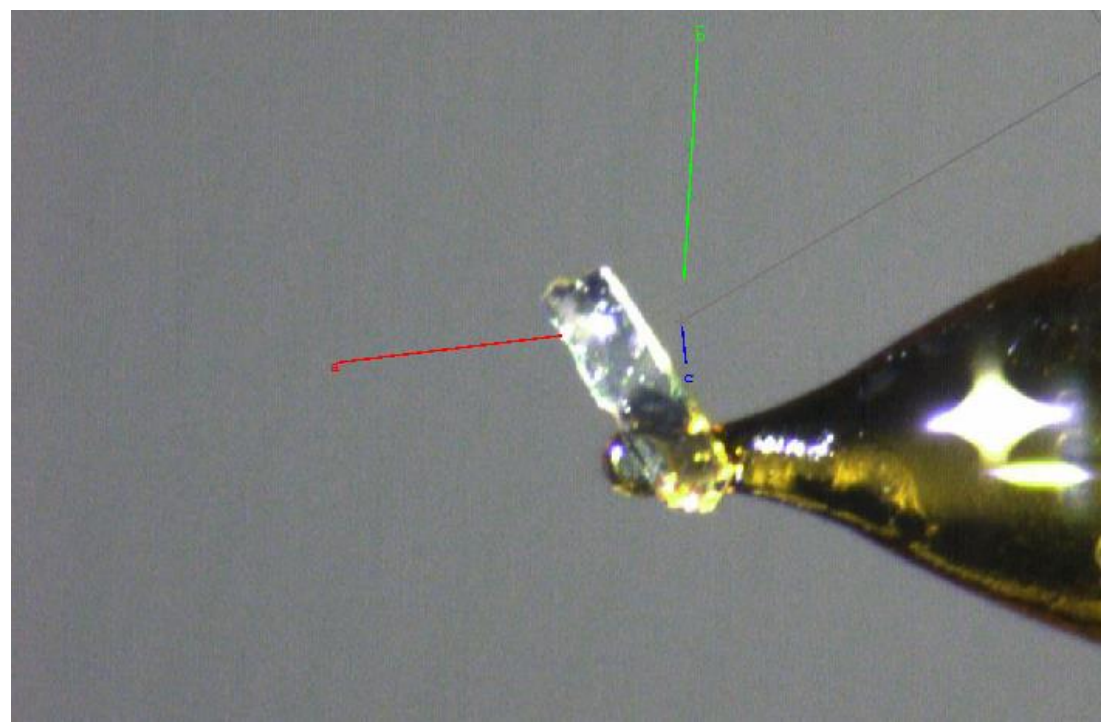

Figure S 22. Form C

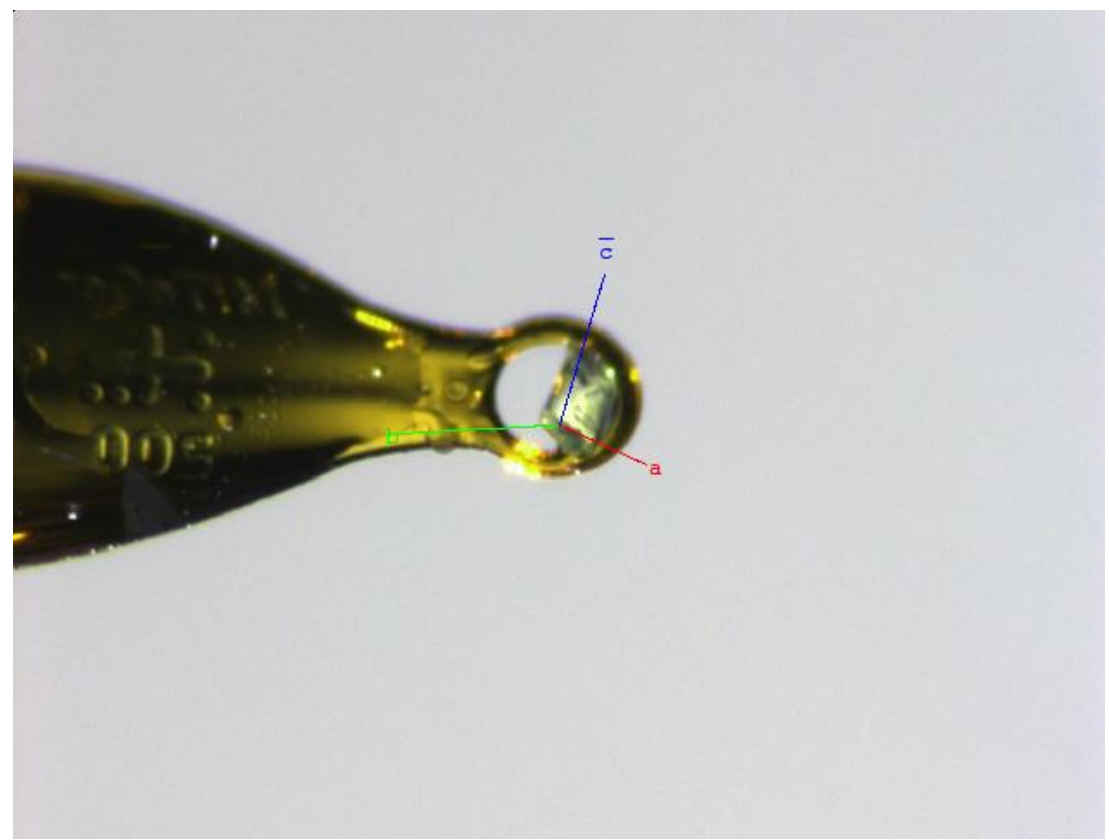

Figure S 23. Form D 


\section{CASCADE EXPERIMENTS}

\section{General Considerations for Cascade Experiments}

Cascade experiments were performed by stirring excess solids of Molecule XXIII in a solvent of choice with a magnetic stir bar. At various timepoints, a portion of the solid was collected and analyzed with PXRD to determine the solid form. Slurry experiments at different temperatures were performed in a temperature-controlled Crystal $16^{\mathrm{TM}}$ or in a freezer (e.g. $-21^{\circ} \mathrm{C}$ ). An example overlay of Powder X-ray diffractograms is shown below.

\section{Cascade Experiment data}

Table S 3. Slurry experiments of Molecule XXIII at $-21^{\circ} \mathrm{C}(\mathrm{D} \rightarrow \mathrm{A} \rightarrow \mathrm{B} \rightarrow \mathrm{C})$

\begin{tabular}{|c|c|c|c|c|c|c|c|}
\hline \multirow{2}{*}{$\begin{array}{c}\text { Temperature, } \\
{ }^{\circ} \mathrm{C}\end{array}$} & \multirow{2}{*}{ Solvent } & \multicolumn{5}{|c|}{ PXRD } & \multirow{2}{*}{ Cascade } \\
\cline { 3 - 6 } & & starting & 2 days & 6 days & 10 days & 14 days & \\
\hline-21 & chloroform & $\mathrm{A}+\mathrm{D}$ & $\mathrm{A}$ & $\mathrm{B}+\mathrm{C}$ & More $\mathrm{C}+\mathrm{B}$ & $\mathrm{C}$ & $\mathrm{D} \rightarrow \mathrm{A} \rightarrow \mathrm{B} \rightarrow \mathrm{C}$ \\
\hline
\end{tabular}

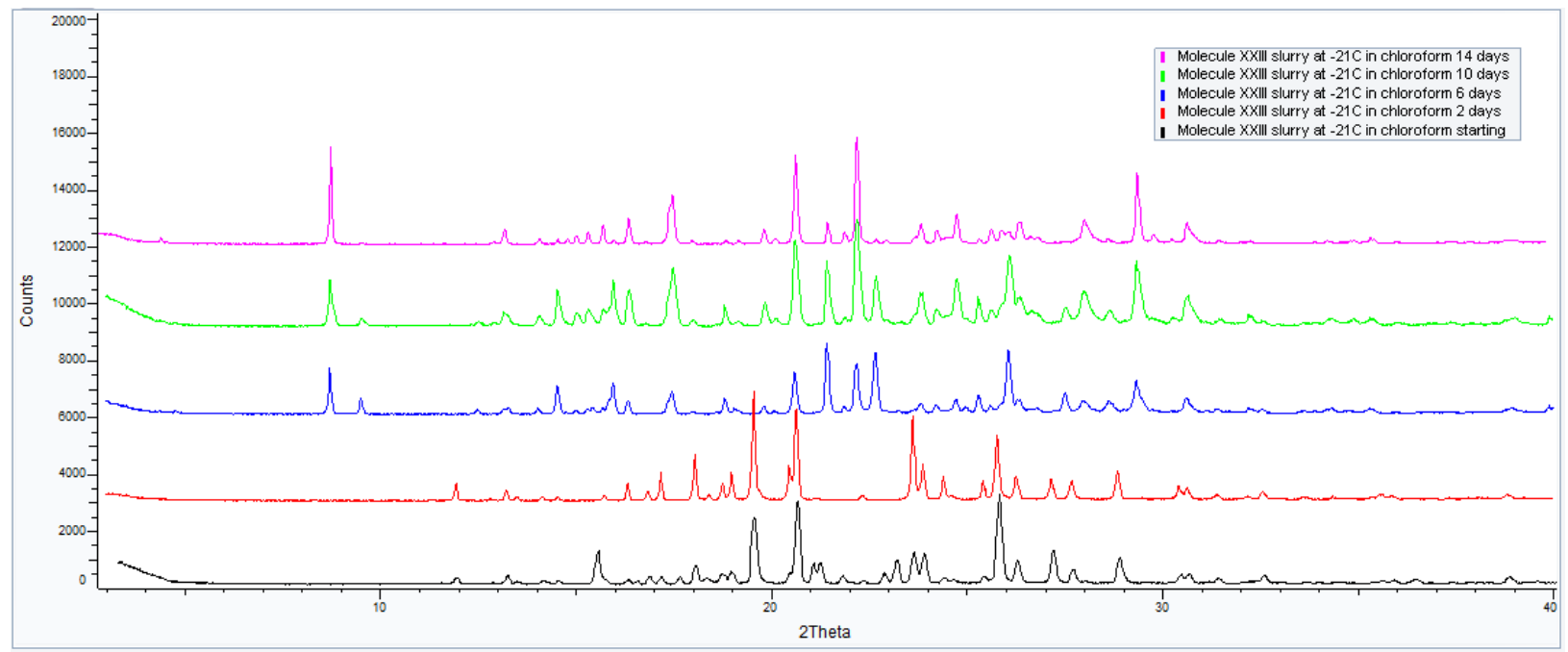

Figure S 24. Overlay PXRD patterns of Molecule XXIII slurry in $\mathrm{CHCl}_{3}$ at $-21^{\circ} \mathrm{C}$

Table S 4. Slurry experiments of Molecule XXIII at $0^{\circ} \mathrm{C}(\mathrm{D} \rightarrow \mathrm{A} \rightarrow \mathrm{C} \rightarrow \mathrm{B})$

\begin{tabular}{|c|c|c|c|c|c|c|}
\hline \multirow{2}{*}{$\begin{array}{c}\text { Temperature, } \\
{ }^{\circ} \mathrm{C}\end{array}$} & \multirow{2}{*}{ Solvent } & \multicolumn{4}{|c|}{ PXRD } & \multirow{2}{*}{ Cascade } \\
\cline { 3 - 6 } & & starting & 5 hours & 30 hours & 3 days & \\
\hline 0 & $\begin{array}{c}\text { 2-methyl } \\
\text { THF }\end{array}$ & D + little A & D + A & B + C & B & D $\rightarrow \mathrm{A} \rightarrow \mathrm{C} \rightarrow \mathrm{B}$ \\
& & & & & \\
\hline
\end{tabular}




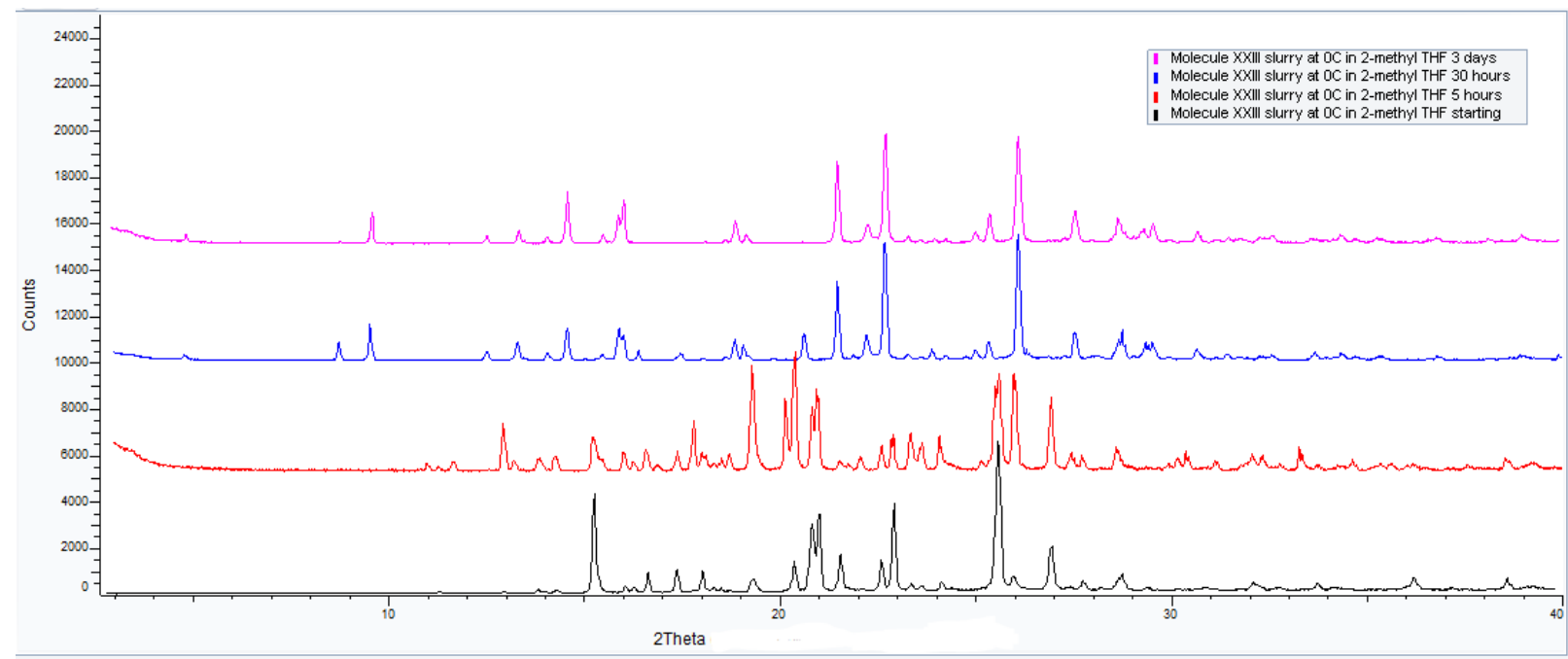

Figure S 25. Overlay PXRD patterns of Molecule XXIII slurry in 2-methyl THF at $0^{\circ} \mathrm{C}$

Table S 5. Slurry experiments of Molecule XXIII at $5^{\circ} \mathrm{C}(\mathrm{D} \rightarrow \mathrm{A} \rightarrow \mathrm{C} \rightarrow \mathrm{B})$

\begin{tabular}{|c|c|c|c|c|c|c|}
\hline \multirow{2}{*}{$\begin{array}{c}\text { Temperature, } \\
{ }^{\circ} \mathrm{C}\end{array}$} & \multirow{2}{*}{ Solvent } & \multicolumn{4}{|c|}{ PXRD } & \multirow{2}{*}{ Cascade } \\
\cline { 3 - 6 } & & starting & 7 hours & 1 day & 6 days & \\
\hline 5 & Ethyl acetate & $\mathrm{A}+\mathrm{D}$ & & $\mathrm{A}$ & $\mathrm{B}$ & $\mathrm{D} \rightarrow \mathrm{A} \rightarrow \mathrm{B}$ \\
\hline 5 & Ethyl acetate & $\mathrm{B}+\mathrm{C}$ & & $\mathrm{B}$ & & $\mathrm{C} \rightarrow \mathrm{B}$ \\
\hline 5 & Ethyl acetate & $\mathrm{A}+\mathrm{B}$ & & $\mathrm{B}$ & & $\mathrm{A} \rightarrow \mathrm{B}$ \\
\hline 5 & Ethyl acetate & $\mathrm{A}+\mathrm{C}$ & $\mathrm{C}$ & & & $\mathrm{A} \rightarrow \mathrm{C}$ \\
\hline
\end{tabular}

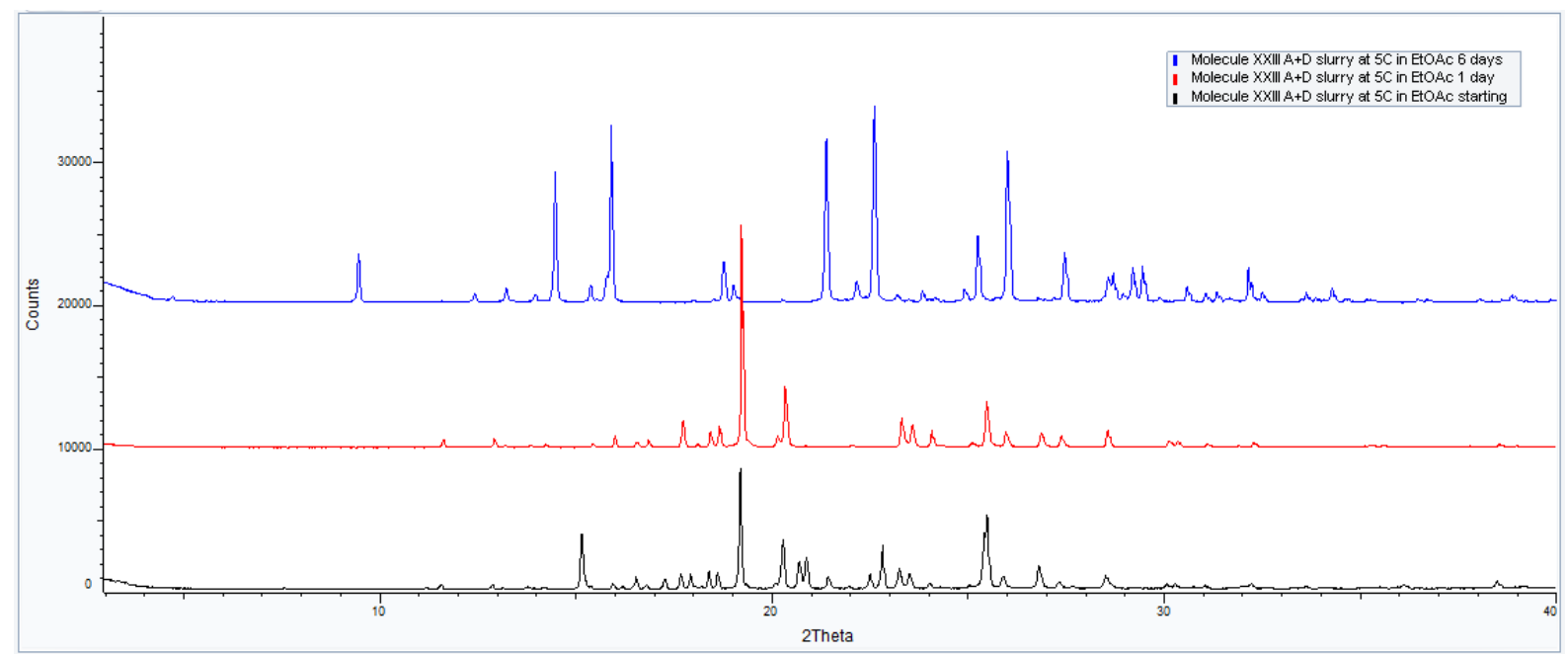

Figure S 26. Overlay PXRD patterns of Molecule XXIII Form A and D slurry in ethyl acetate at $5^{\circ} \mathrm{C}$ 
Five Degrees of Separation: Characterization and Temperature Stability Profiles for the Polymorphs of PD-0118057 (Molecule XXIII)- Supporting Information

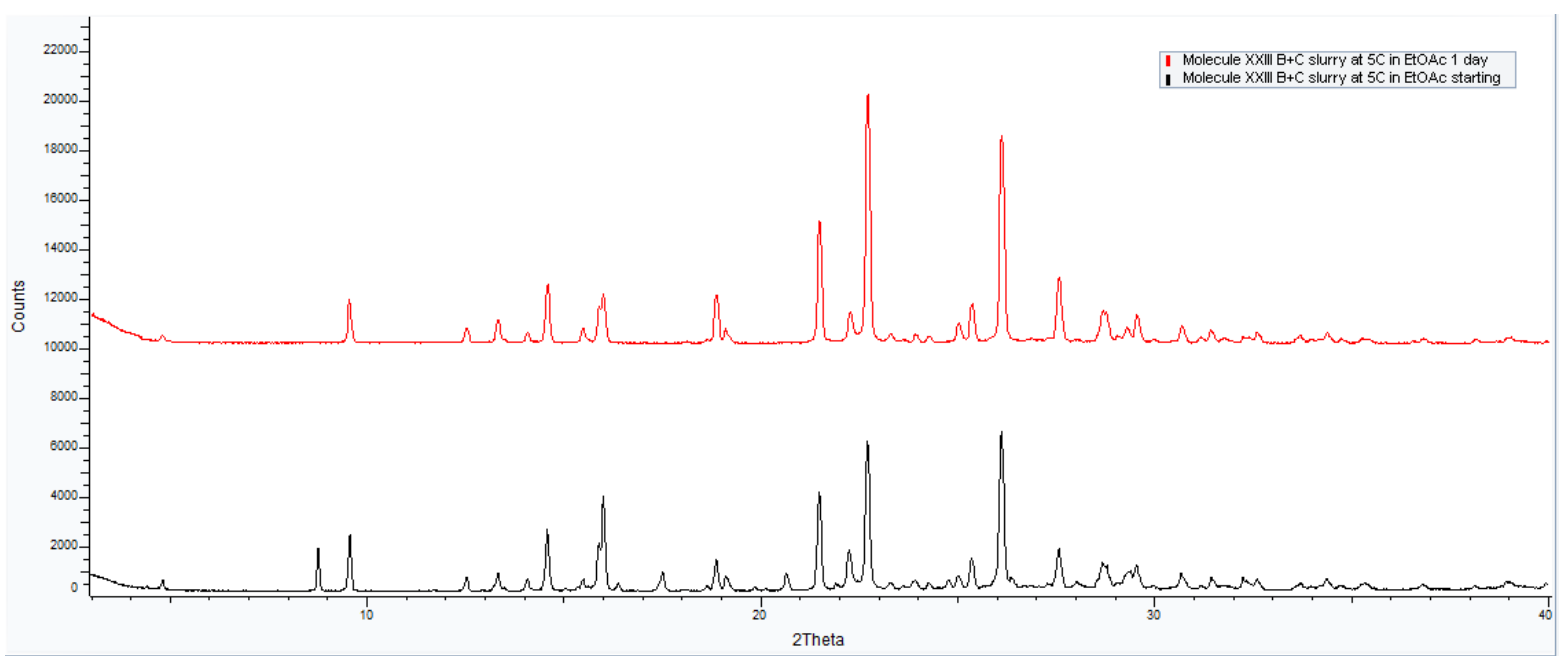

Figure S 27. Overlay PXRD patterns of Molecule XXIII Form B and C slurry in ethyl acetate at $5^{\circ} \mathrm{C}$

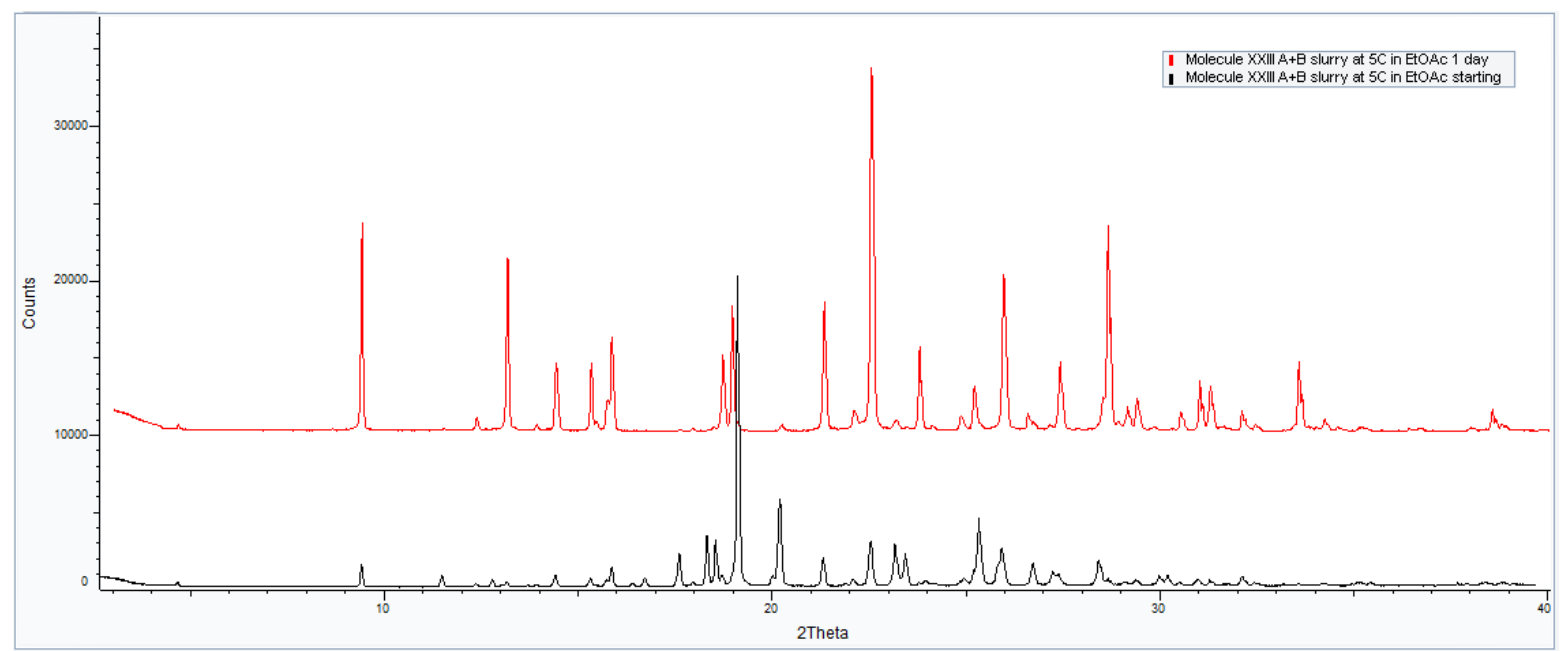

Figure S 28. Overlay PXRD patterns of Molecule XXIII Form A and B slurry in ethyl acetate at $5^{\circ} \mathrm{C}$

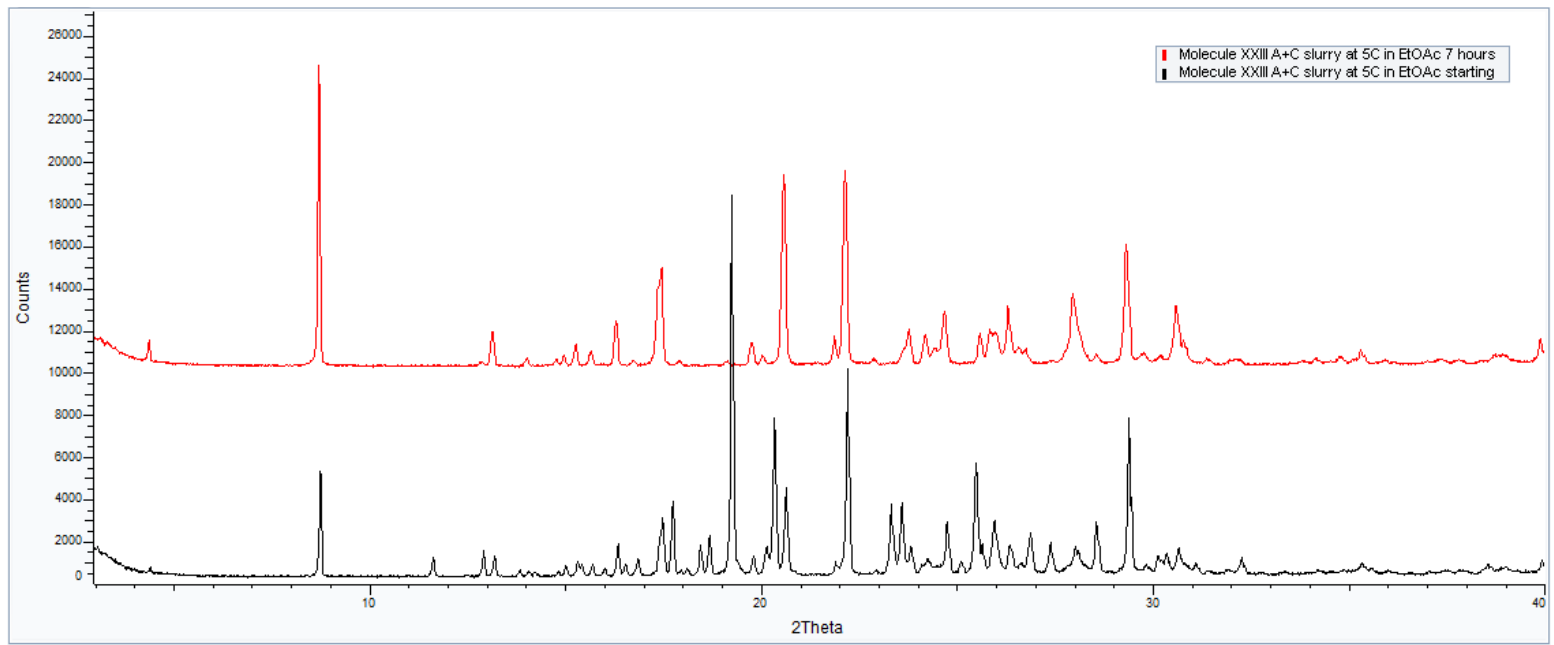

Figure S 29. Overlay PXRD patterns of Molecule XXIII Form A and C slurry in ethyl acetate at $5^{\circ} \mathrm{C}$ 
Table S 6. Slurry experiments of Molecule XXIII at $10^{\circ} \mathrm{C}(\mathrm{D} \rightarrow \mathrm{A} \rightarrow \mathrm{C} \rightarrow \mathrm{B})$

\begin{tabular}{|c|c|c|c|c|c|c|c|}
\hline \multirow{2}{*}{$\begin{array}{c}\text { Temperature, } \\
{ }^{\circ} \mathrm{C}\end{array}$} & \multirow{2}{*}{ Solvent } & \multicolumn{5}{|c|}{ PXRD } & \multirow{2}{*}{ Cascade } \\
\cline { 3 - 7 } & & starting & 3 hours & 1 day & 2 days & 6 days & \\
\hline 10 & Ethyl acetate & $\mathrm{A}+\mathrm{D}$ & & $\mathrm{A}$ & & & $\mathrm{D} \rightarrow \mathrm{A}$ \\
\hline 10 & Ethyl acetate & $\mathrm{A}+\mathrm{C}$ & $\mathrm{C}$ & & & & $\mathrm{A} \rightarrow \mathrm{C}$ \\
\hline 10 & Ethyl acetate & $\mathrm{C}+\mathrm{D}$ & $\mathrm{C}$ & & & & $\mathrm{D} \rightarrow \mathrm{C}$ \\
\hline 10 & Ethyl acetate & $\mathrm{A}+\mathrm{B}$ & & & $\mathrm{B}$ & & $\mathrm{A} \rightarrow \mathrm{B}$ \\
\hline 10 & Ethyl acetate & $\mathrm{B}+\mathrm{C}$ & & & & $\mathrm{B}$ & $\mathrm{C} \rightarrow \mathrm{B}$ \\
\hline
\end{tabular}

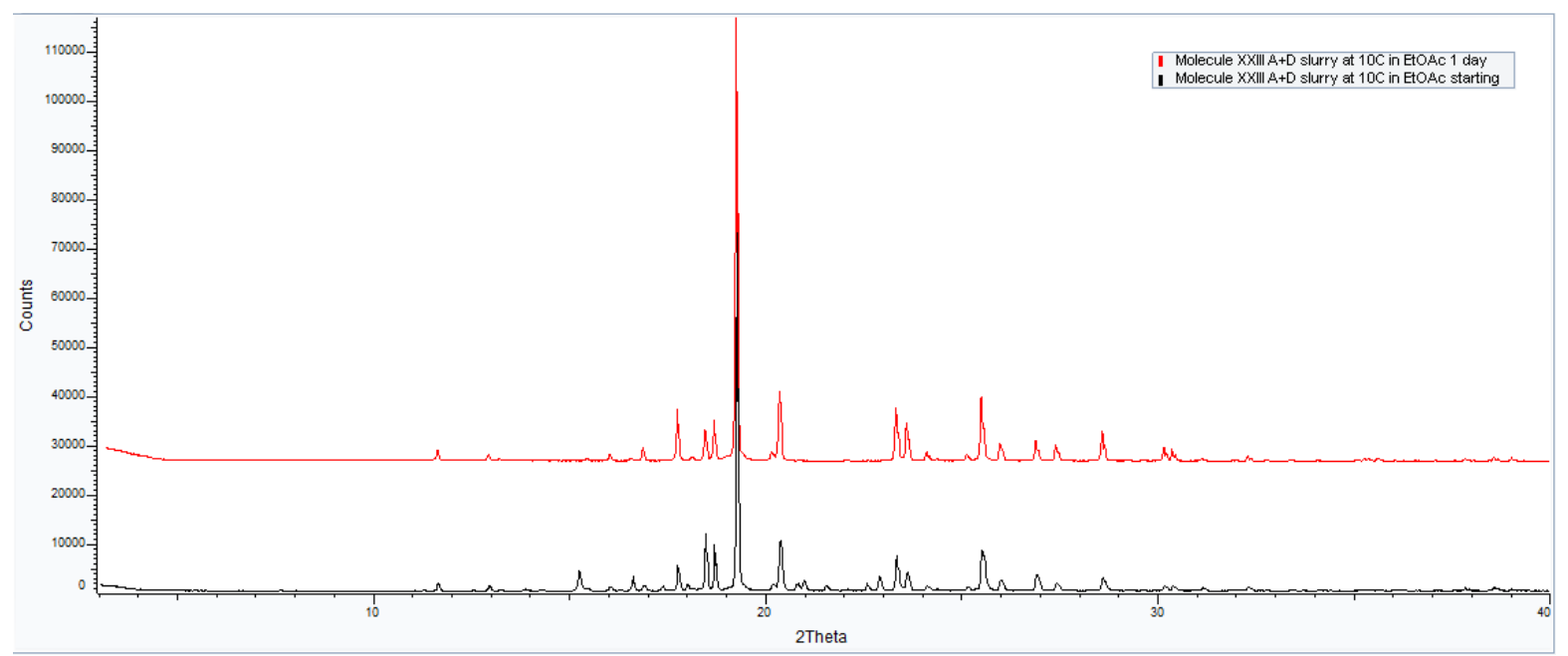

Figure S 30. Overlay PXRD patterns of Molecule XXIII Form A and D slurry in ethyl acetate at $10^{\circ} \mathrm{C}$

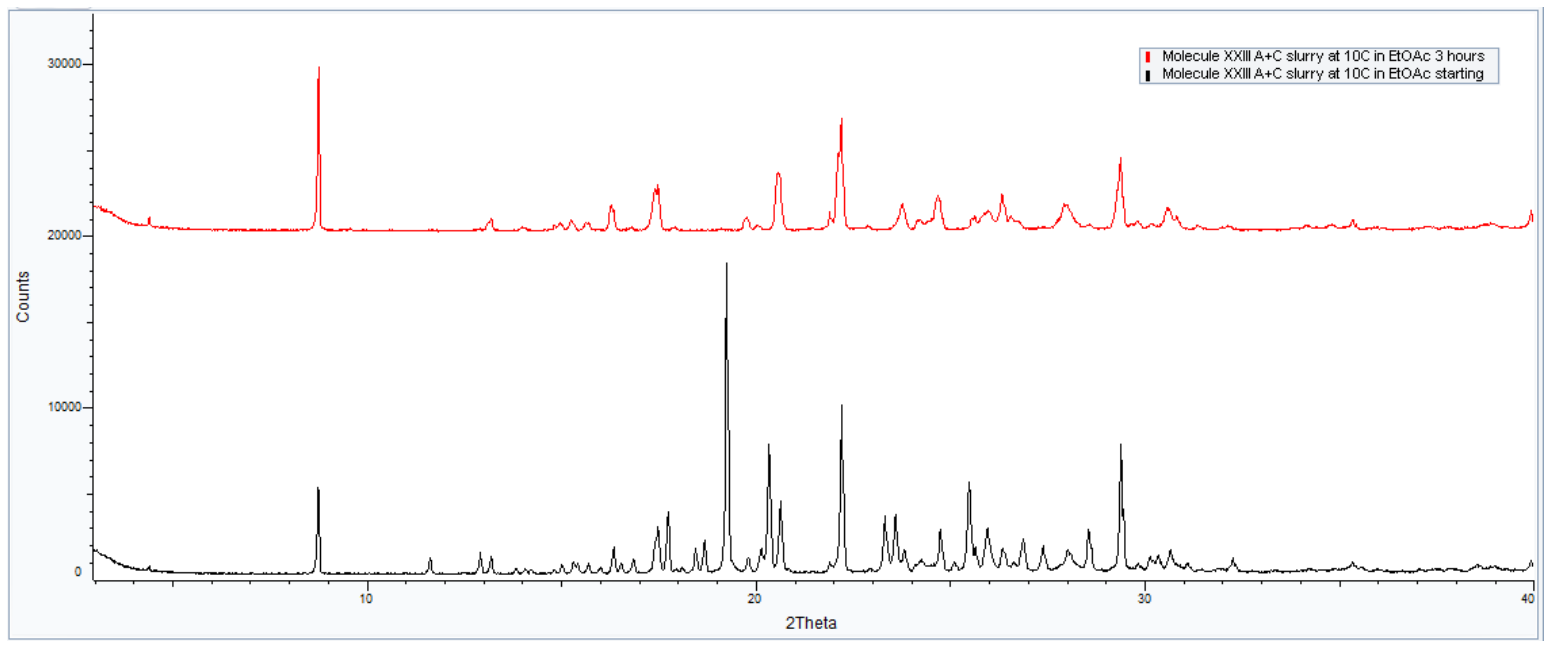

Figure S 31. Overlay PXRD patterns of Molecule XXIII Form A and C slurry in ethyl acetate at $10^{\circ} \mathrm{C}$ 
Five Degrees of Separation: Characterization and Temperature Stability Profiles for the Polymorphs of PD-0118057 (Molecule XXIII)- Supporting Information

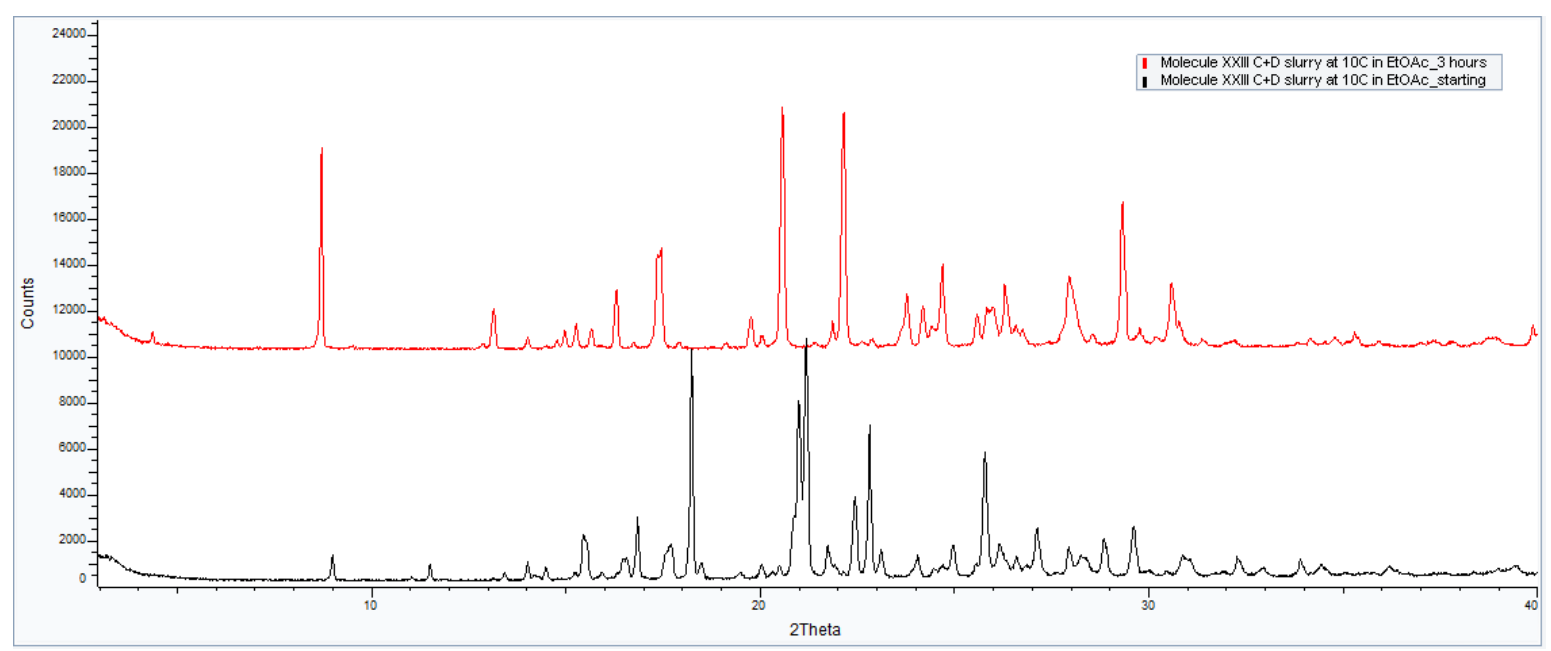

Figure S 32. Overlay PXRD patterns of Molecule XXIII Form C and D slurry in ethyl acetate at $10^{\circ} \mathrm{C}$

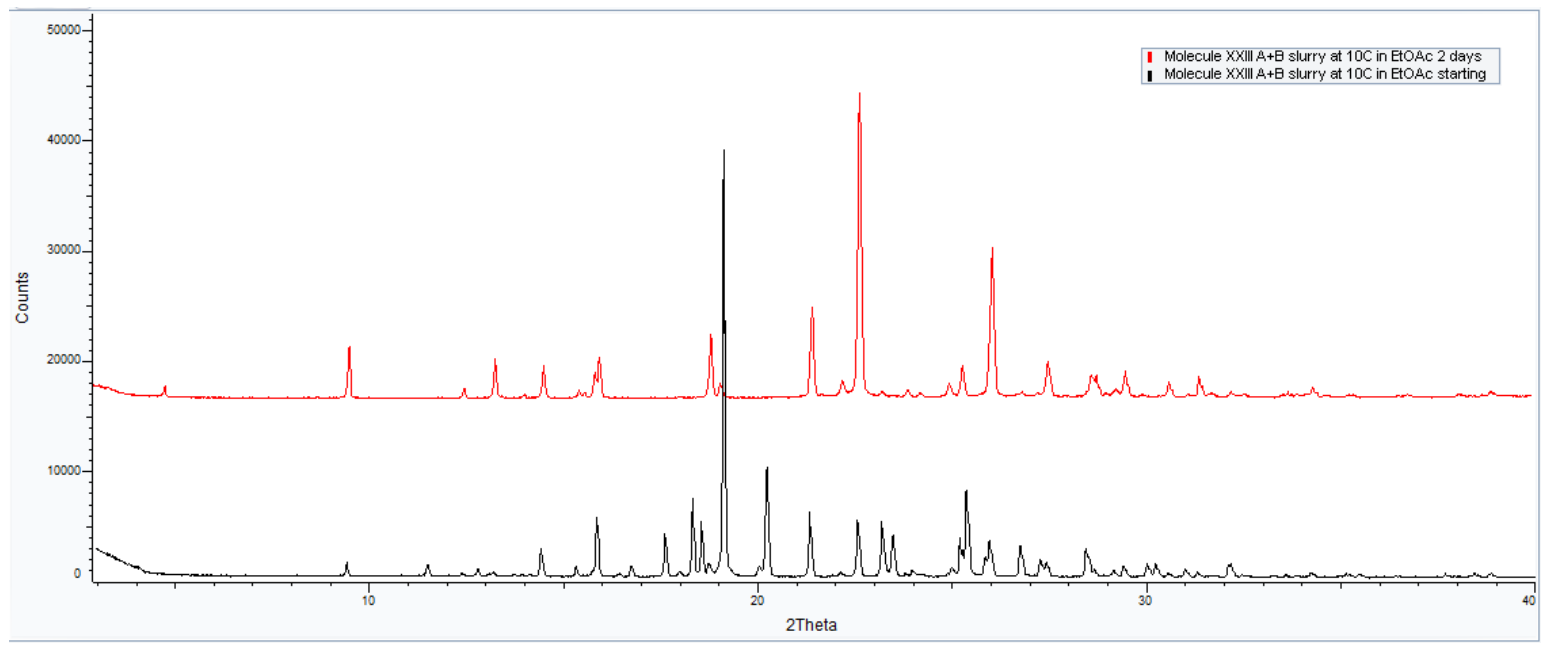

Figure S 33. Overlay PXRD patterns of Molecule XXIII Form A and B slurry in ethyl acetate at $10^{\circ} \mathrm{C}$

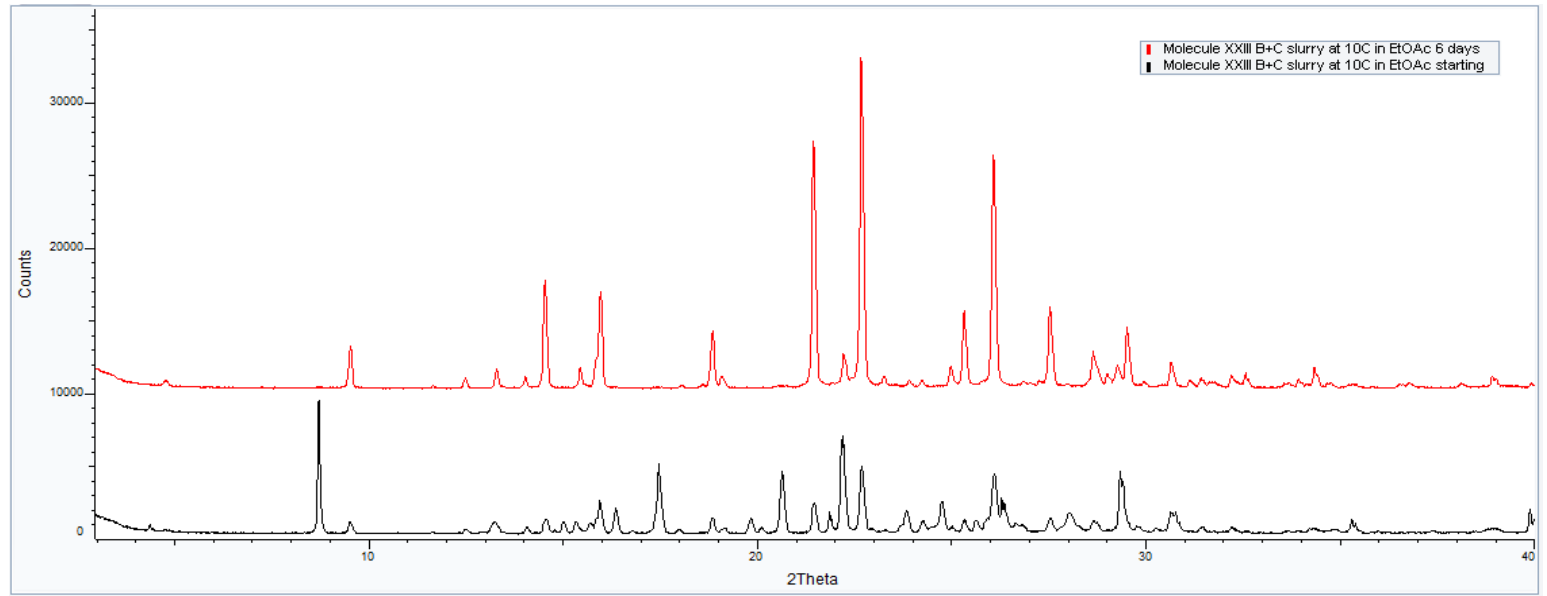

Figure S 34. Overlay PXRD patterns of Molecule XXIII Form B and C slurry in ethyl acetate at $10^{\circ} \mathrm{C}$ 
Table S 7. Slurry experiments of Molecule XXIII at $15^{\circ} \mathrm{C}(\mathrm{D} \rightarrow \mathrm{C} \rightarrow \mathrm{A} \rightarrow \mathrm{B})$

\begin{tabular}{|c|c|c|c|c|c|c|}
\hline \multirow{2}{*}{$\begin{array}{c}\text { Temperature, } \\
{ }^{\circ} \mathrm{C}\end{array}$} & \multirow{2}{*}{ Solvent } & \multicolumn{4}{|c|}{ PXRD } & \multirow{2}{*}{ Cascade } \\
\cline { 3 - 6 } & & starting & 6.5 hours & 1 day & 2 days & \\
\hline 15 & Ethyl acetate & $\mathrm{A}+\mathrm{B}$ & & $\mathrm{B}$ & & $\mathrm{A} \rightarrow \mathrm{B}$ \\
\hline 15 & Ethyl acetate & $\mathrm{A}+\mathrm{C}$ & & $\mathrm{A}$ & & $\mathrm{C} \rightarrow \mathrm{A}$ \\
\hline 15 & Ethyl acetate & $\mathrm{A}+\mathrm{D}$ & & & $\mathrm{A}$ & $\mathrm{D} \rightarrow \mathrm{A}$ \\
\hline 15 & Ethyl acetate & $\mathrm{B}+\mathrm{C}$ & $\mathrm{B}$ & & & $\mathrm{C} \rightarrow \mathrm{B}$ \\
\hline 15 & Ethyl acetate & $\mathrm{B}+\mathrm{D}$ & $\mathrm{B}$ & & & $\mathrm{D} \rightarrow \mathrm{B}$ \\
\hline 15 & Ethyl acetate & $\mathrm{C}+\mathrm{D}$ & & $\mathrm{C}+\mathrm{D}$ & $\mathrm{C}+$ little $\mathrm{B}$ & $\mathrm{D} \rightarrow \mathrm{C}$ \\
\hline
\end{tabular}

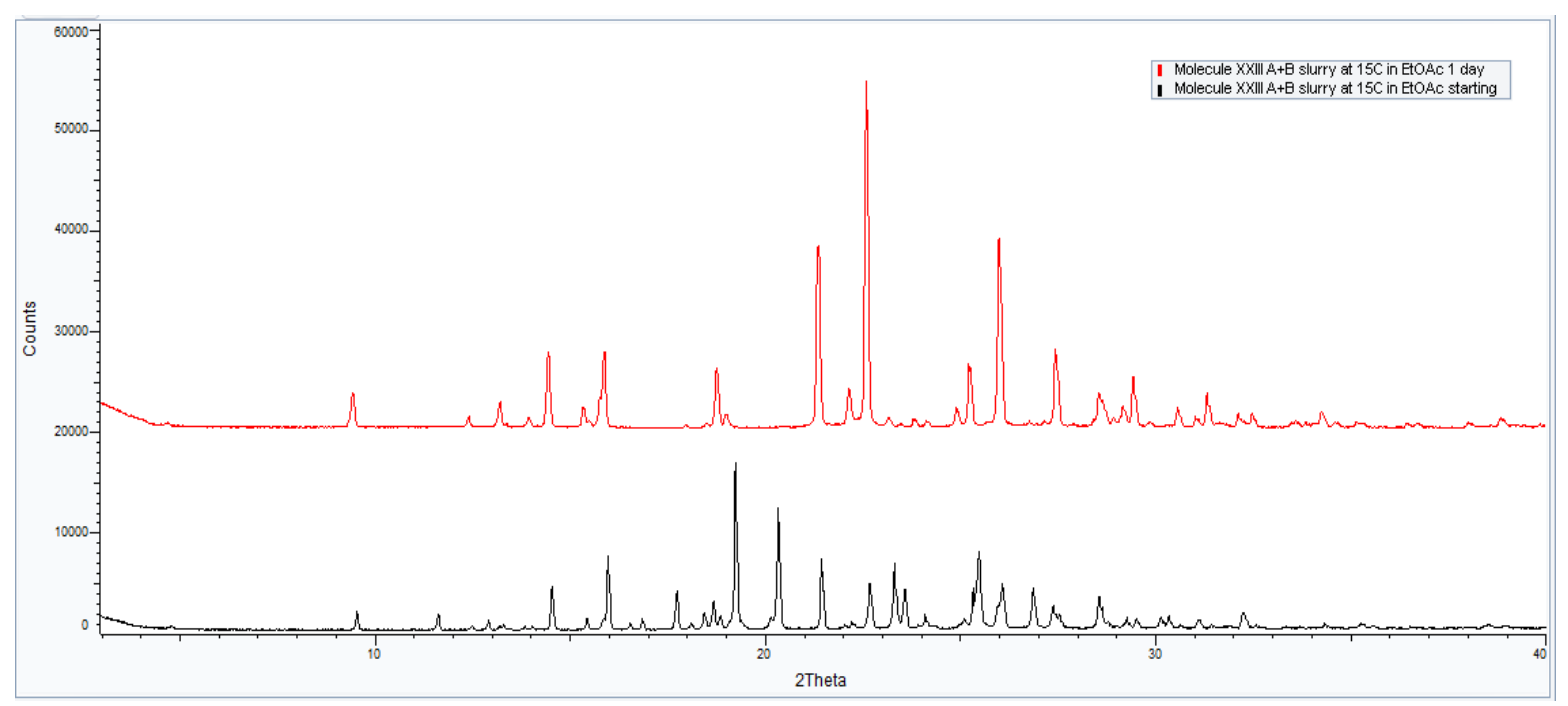

Figure S 35. Overlay PXRD patterns of Molecule XXIII Form A and B slurry in ethyl acetate at $15^{\circ} \mathrm{C}$

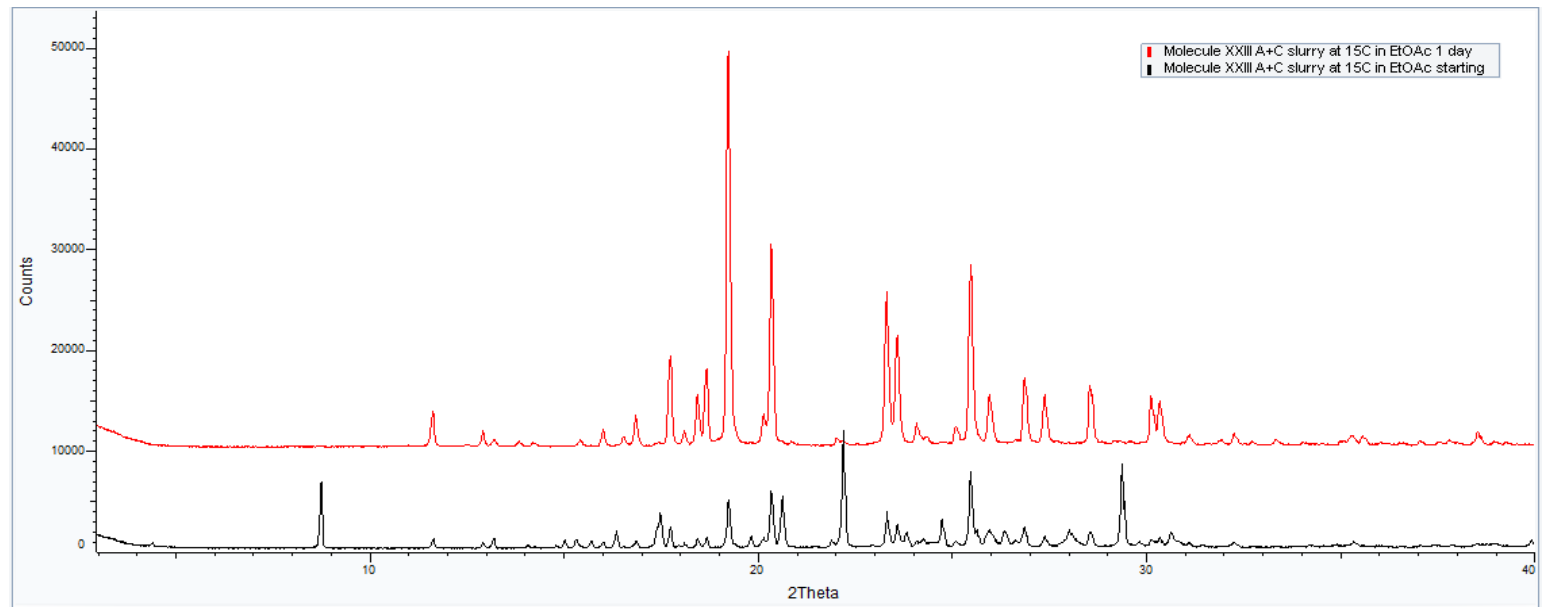

Figure S 36. Overlay PXRD patterns of Molecule XXIII Form A and C slurry in ethyl acetate at $15^{\circ} \mathrm{C}$ 
Five Degrees of Separation: Characterization and Temperature Stability Profiles for the Polymorphs of PD-0118057 (Molecule XXIII)- Supporting Information

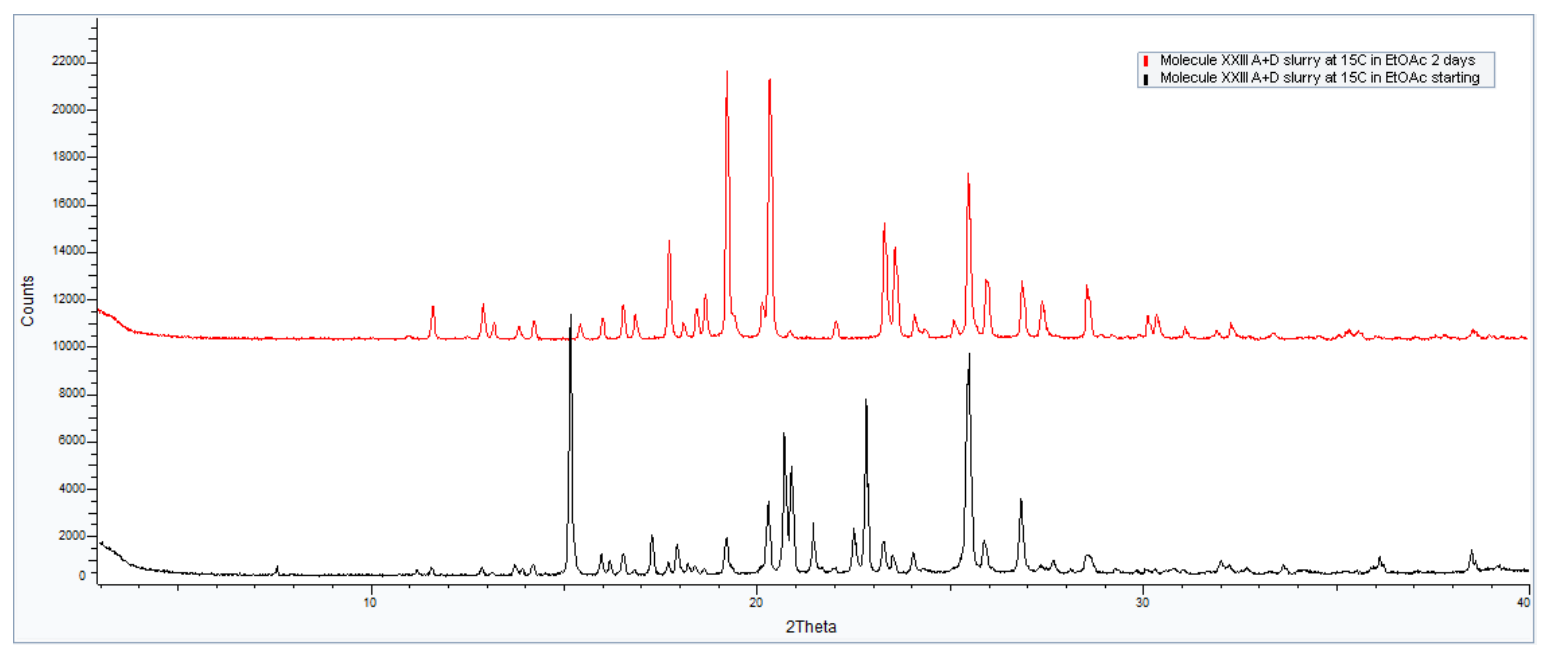

Figure S 37. Overlay PXRD patterns of Molecule XXIII Form A and D slurry in ethyl acetate at $15^{\circ} \mathrm{C}$

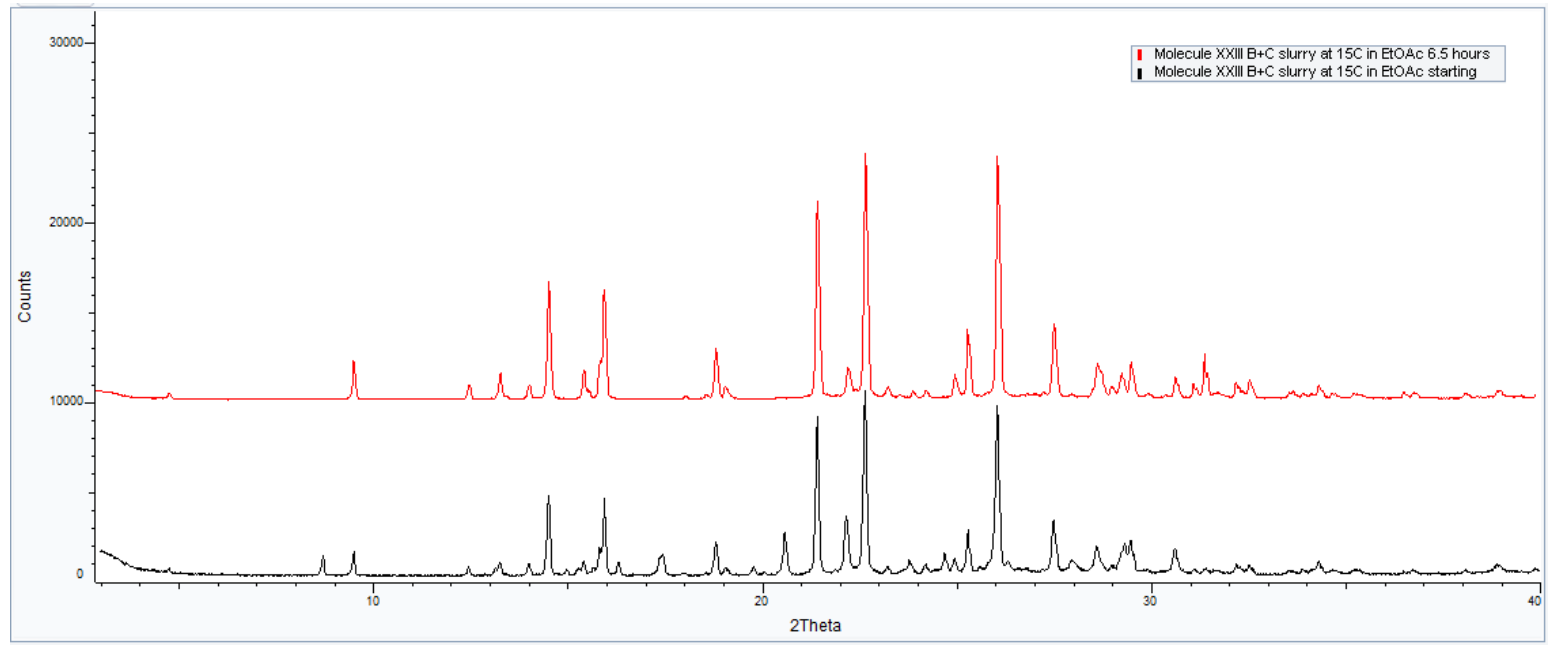

Figure S 38. Overlay PXRD patterns of Molecule XXIII Form B and C slurry in ethyl acetate at $15^{\circ} \mathrm{C}$

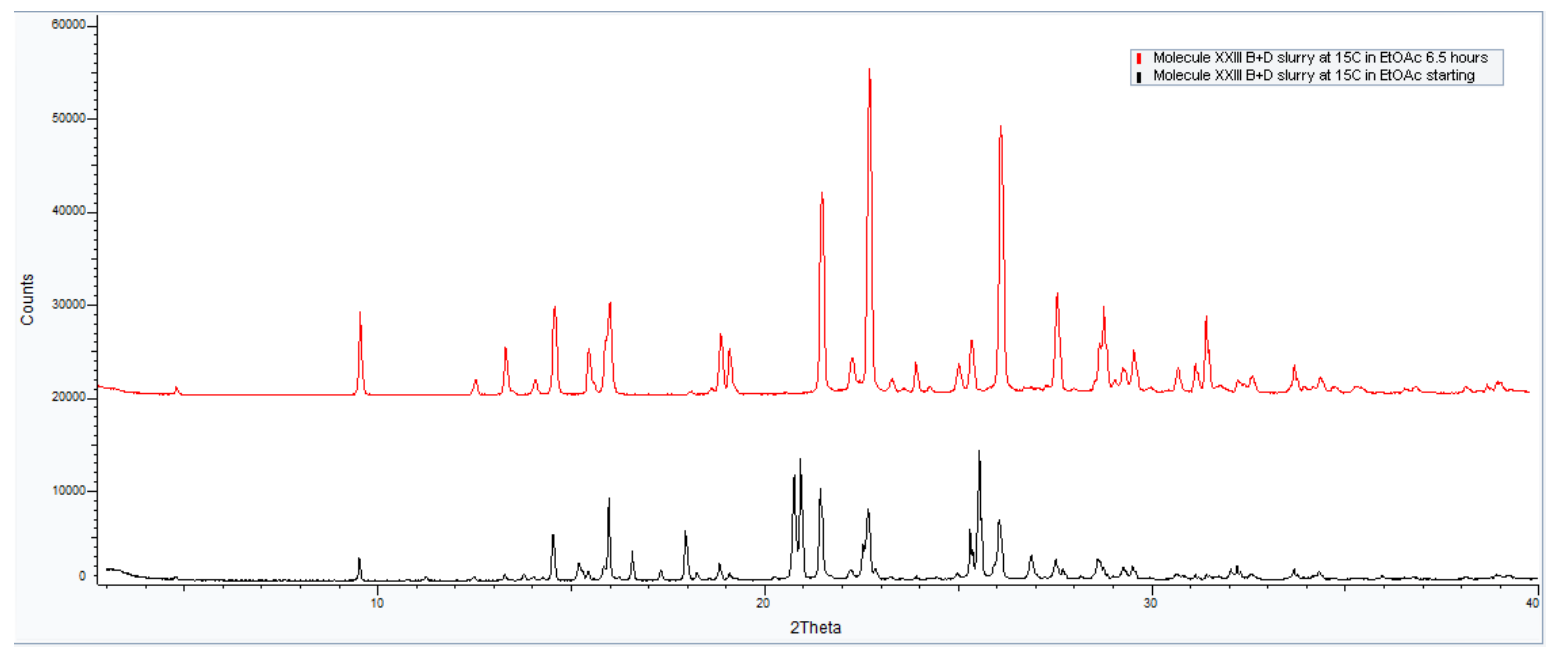

Figure S 39. Overlay PXRD patterns of Molecule XXIII Form B and D slurry in ethyl acetate at $15^{\circ} \mathrm{C}$ 


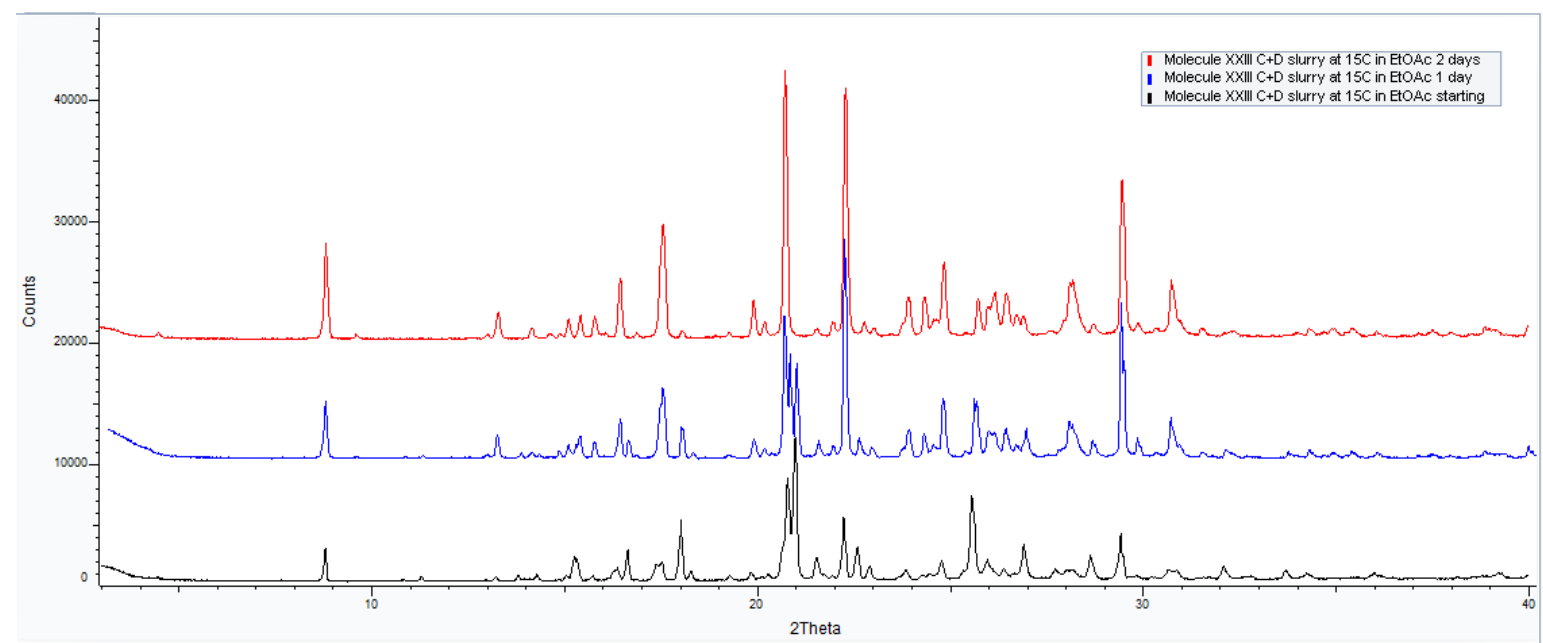

Figure S 40. Overlay PXRD patterns of Molecule XXIII Form C and D slurry in ethyl acetate at $15^{\circ} \mathrm{C}$

Table S 8. Slurry experiments of Molecule XXIII at $16^{\circ} \mathrm{C}(\mathrm{C} \rightarrow \mathrm{D} \rightarrow \mathrm{A} \rightarrow \mathrm{B})$

\begin{tabular}{|c|c|c|c|c|c|c|}
\hline \multirow{2}{*}{$\begin{array}{c}\text { Temperature, } \\
{ }^{\circ} \mathrm{C}\end{array}$} & \multirow{2}{*}{ Solvent } & \multicolumn{4}{|c|}{ PXRD } & \multirow{2}{*}{ Cascade } \\
\cline { 3 - 6 } & & starting & 1 day & 2 days & 5 days & \\
\hline 16 & Ethyl acetate & $\mathrm{A}+\mathrm{B}$ & & $\mathrm{B}$ & & $\mathrm{A} \rightarrow \mathrm{B}$ \\
\hline 16 & Ethyl acetate & $\mathrm{A}+\mathrm{D}$ & $\mathrm{A}$ & & & $\mathrm{D} \rightarrow \mathrm{A}$ \\
\hline 16 & Ethyl acetate & $\mathrm{B}+\mathrm{D}$ & $\mathrm{B}$ & & & $\mathrm{D} \rightarrow \mathrm{B}$ \\
\hline 16 & Ethyl acetate & $\mathrm{C}+\mathrm{D}$ & $\mathrm{D}+\mathrm{C}$ & & More D+C & $\mathrm{C} \rightarrow \mathrm{D}$ \\
\hline
\end{tabular}

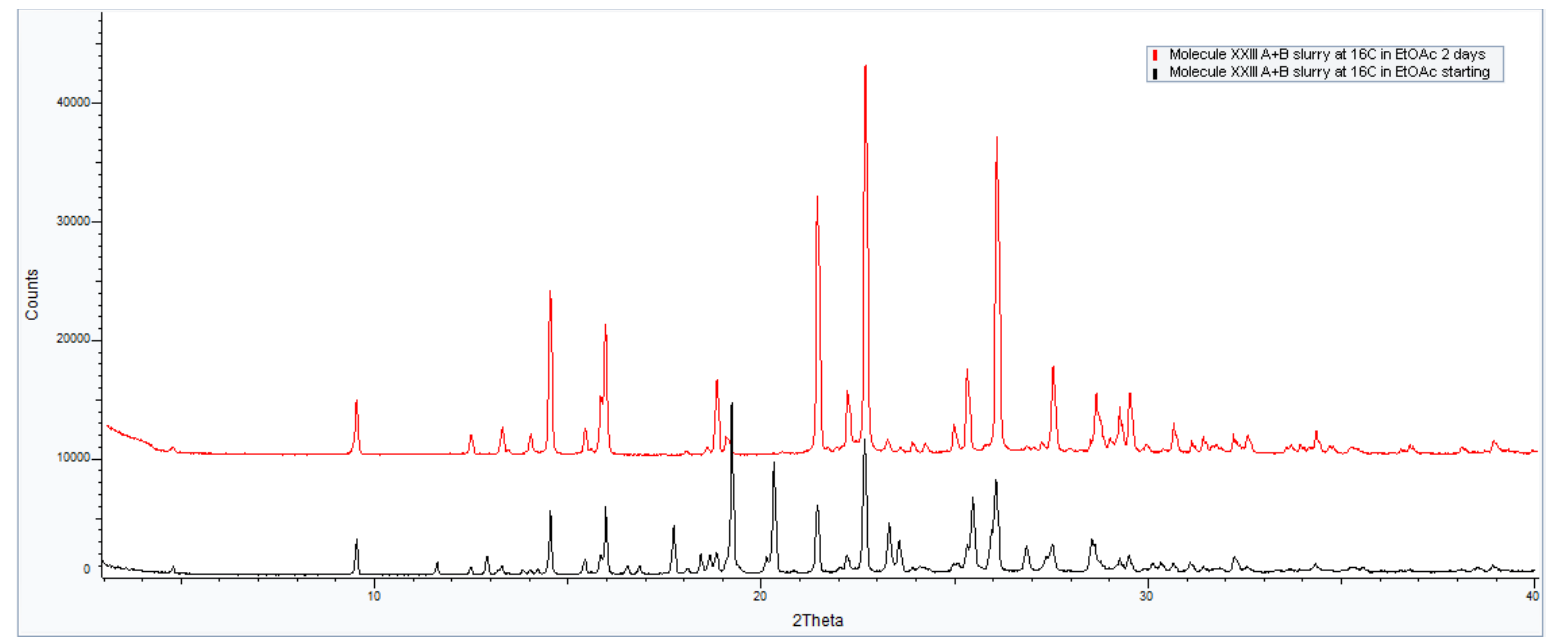

Figure S 41. Overlay PXRD patterns of Molecule XXIII Form A and B slurry in ethyl acetate at $16^{\circ} \mathrm{C}$ 


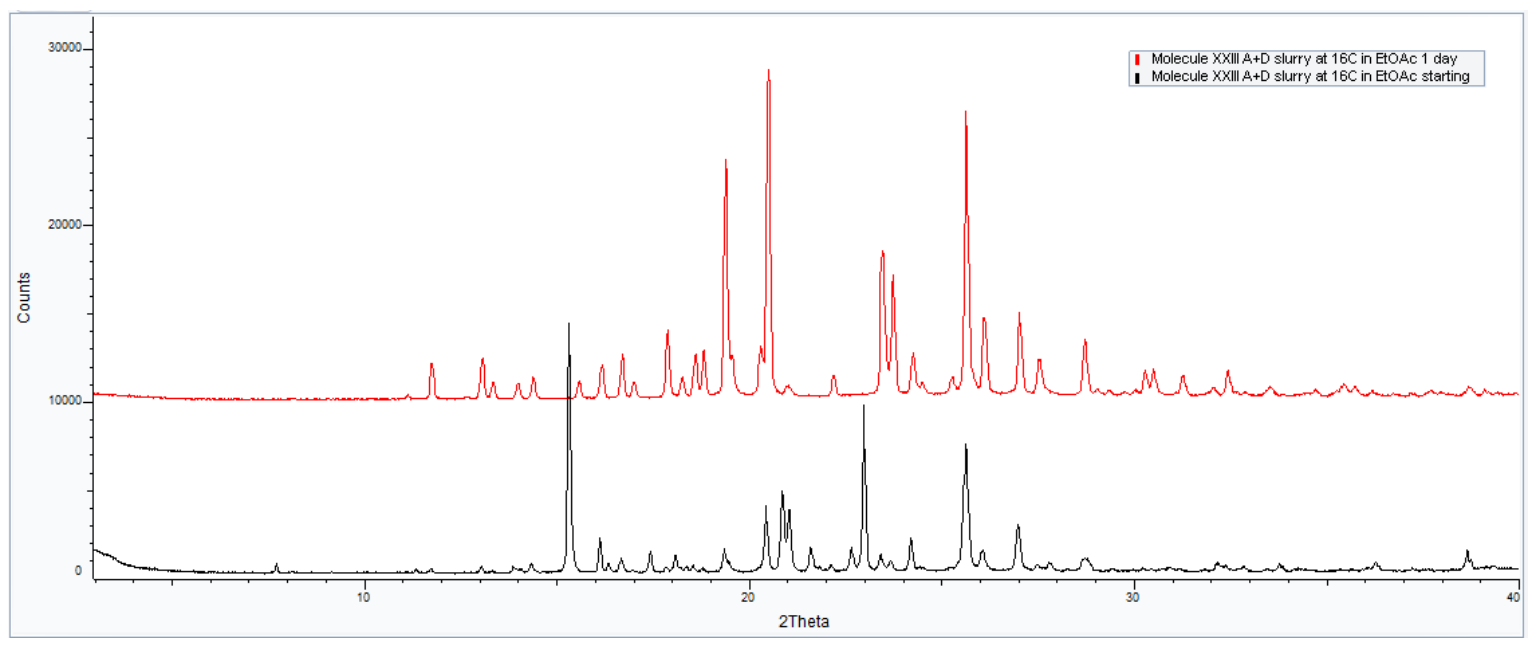

Figure S 42. Overlay PXRD patterns of Molecule XXIII Form A and D slurry in ethyl acetate at $16^{\circ} \mathrm{C}$

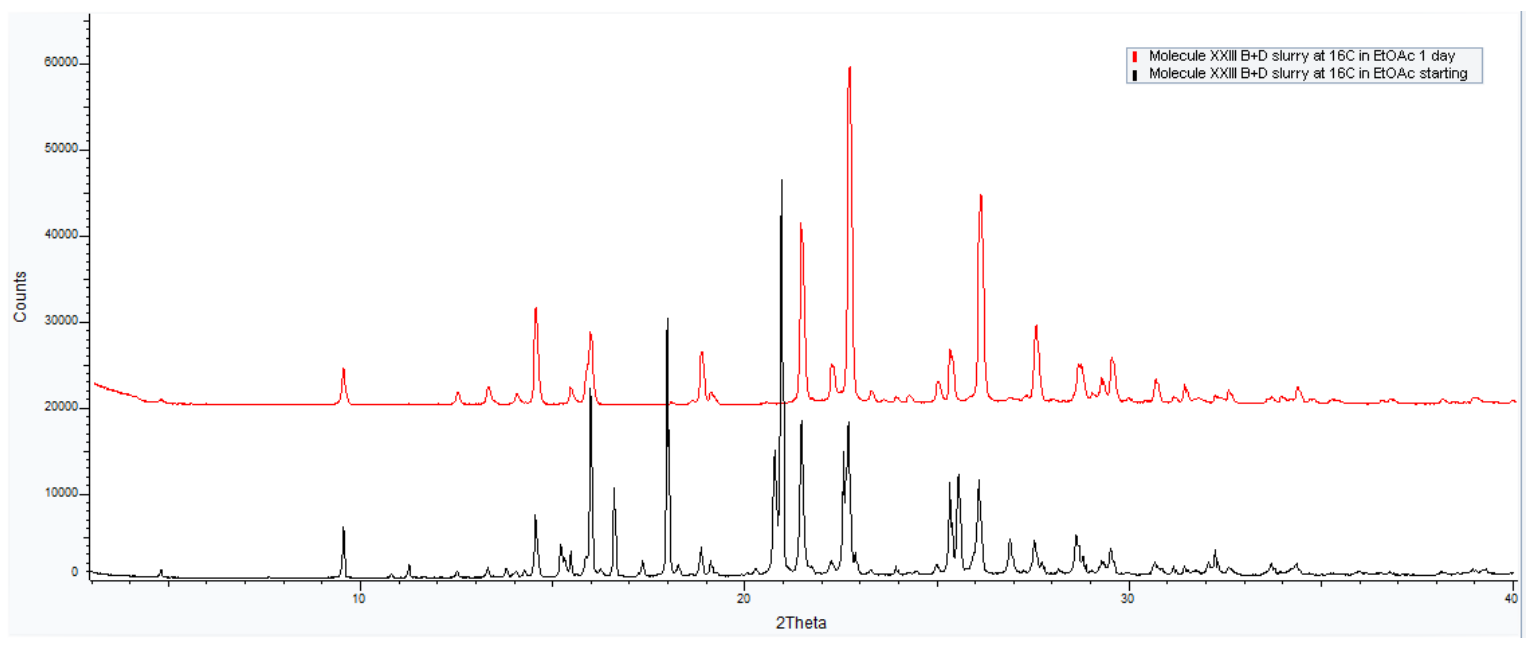

Figure S 43. Overlay PXRD patterns of Molecule XXIII Form B and D slurry in ethyl acetate at $16^{\circ} \mathrm{C}$

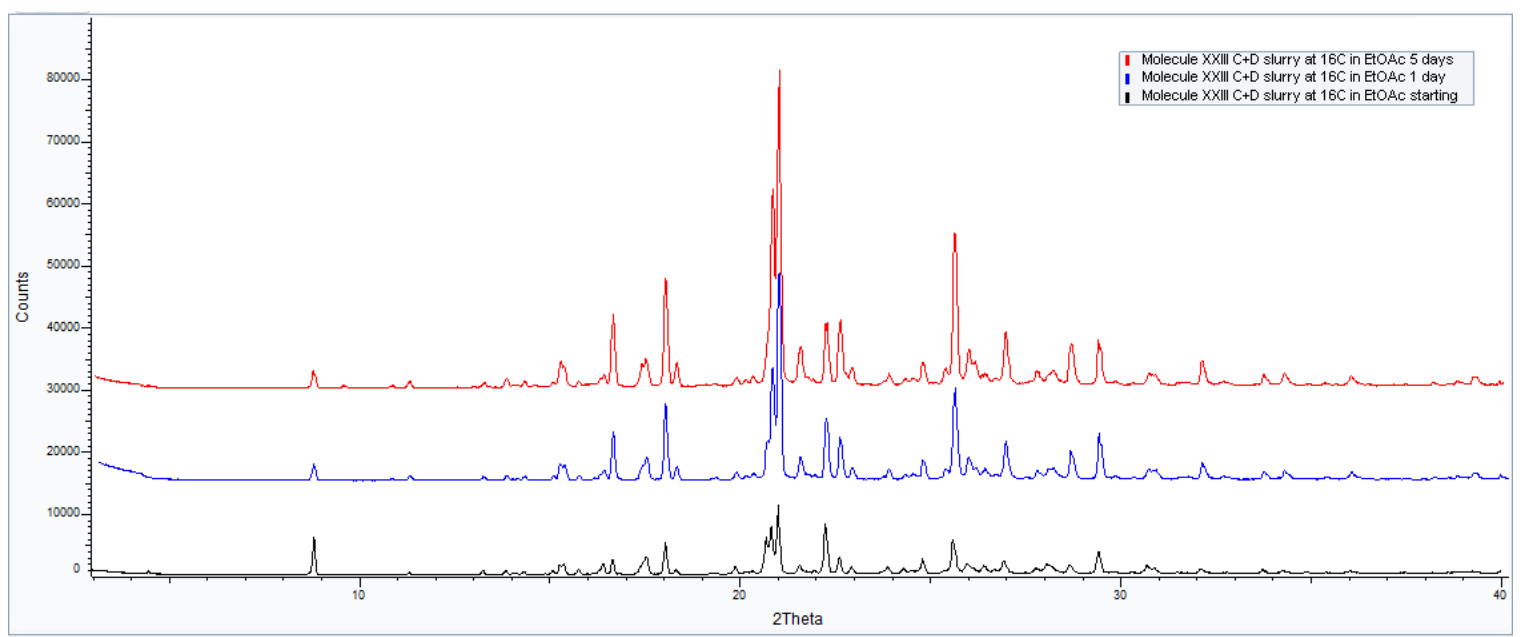

Figure S 44. Overlay PXRD pattern of Molecule XXIII Form C and D slurry in ethyl acetate at $16^{\circ} \mathrm{C}$ 
Table S 9. Slurry experiments of Molecule XXIII at $17^{\circ} \mathrm{C}(\mathrm{C} \rightarrow \mathrm{D} \rightarrow \mathrm{B} \rightarrow \mathrm{A})$

\begin{tabular}{|c|c|c|c|c|c|}
\hline \multirow{2}{*}{$\begin{array}{c}\text { Temperature, } \\
{ }^{\circ} \mathrm{C}\end{array}$} & \multirow{2}{*}{ Solvent } & \multicolumn{3}{|c|}{ PXRD } & \multirow{2}{*}{ Cascade } \\
\cline { 3 - 5 } & & starting & 1 day & 3 days & \\
\hline 17 & Ethyl acetate & $\mathrm{A}+\mathrm{B}$ & & $\mathrm{A}$ & $\mathrm{B} \rightarrow \mathrm{A}$ \\
\hline 17 & Ethyl acetate & $\mathrm{A}+\mathrm{D}$ & $\mathrm{A}$ & & $\mathrm{D} \rightarrow \mathrm{A}$ \\
\hline 17 & Ethyl acetate & $\mathrm{B}+\mathrm{D}$ & $\mathrm{B}$ & & $\mathrm{D} \rightarrow \mathrm{B}$ \\
\hline 17 & Ethyl acetate & $\mathrm{C}+\mathrm{D}$ & $\mathrm{D}$ & & $\mathrm{C} \rightarrow \mathrm{D}$ \\
\hline
\end{tabular}

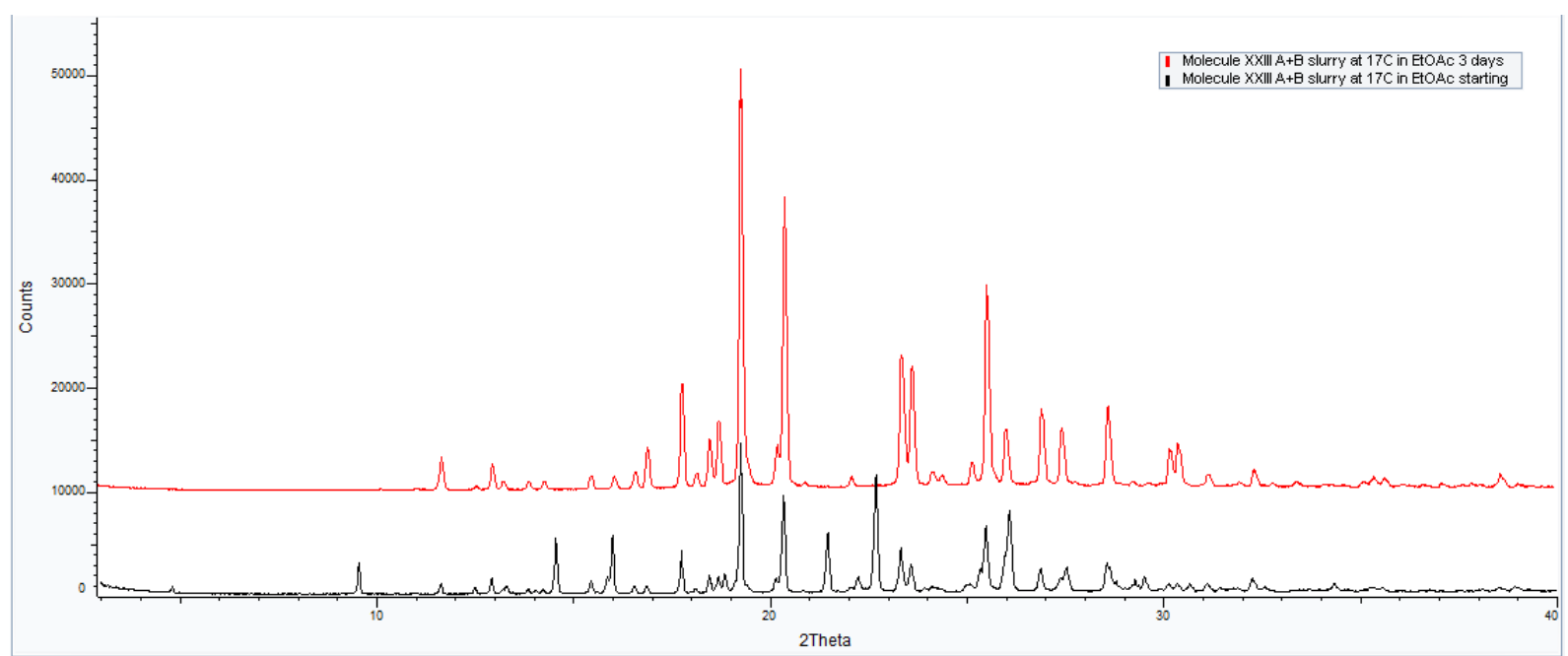

Figure S 45. Overlay PXRD patterns of Molecule XXIII Form A and B slurry in ethyl acetate at $17^{\circ} \mathrm{C}$

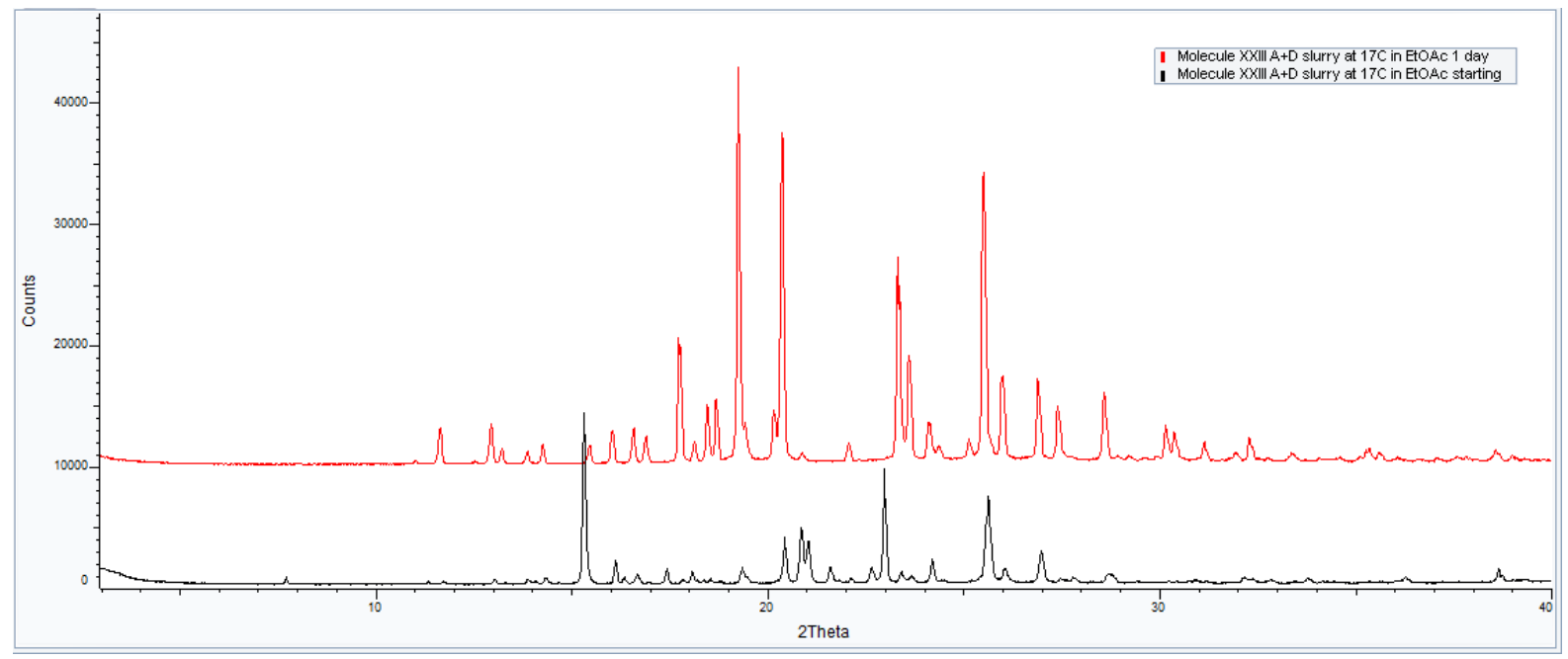

Figure S 46. Overlay PXRD patterns of Molecule XXIII Form A and D slurry in ethyl acetate at $17^{\circ} \mathrm{C}$ 


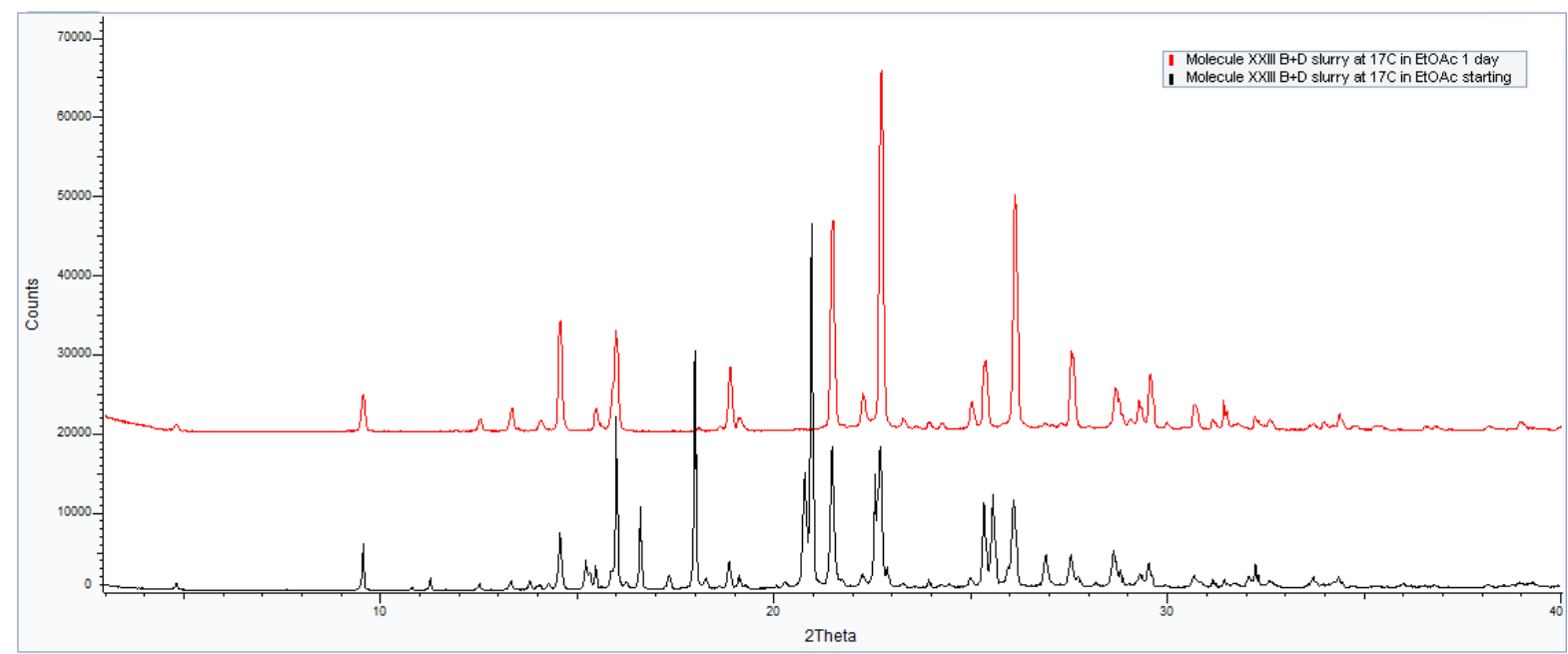

Figure S 47. Overlay PXRD patterns of Molecule XXIII Form B and D slurry in ethyl acetate at $17^{\circ} \mathrm{C}$

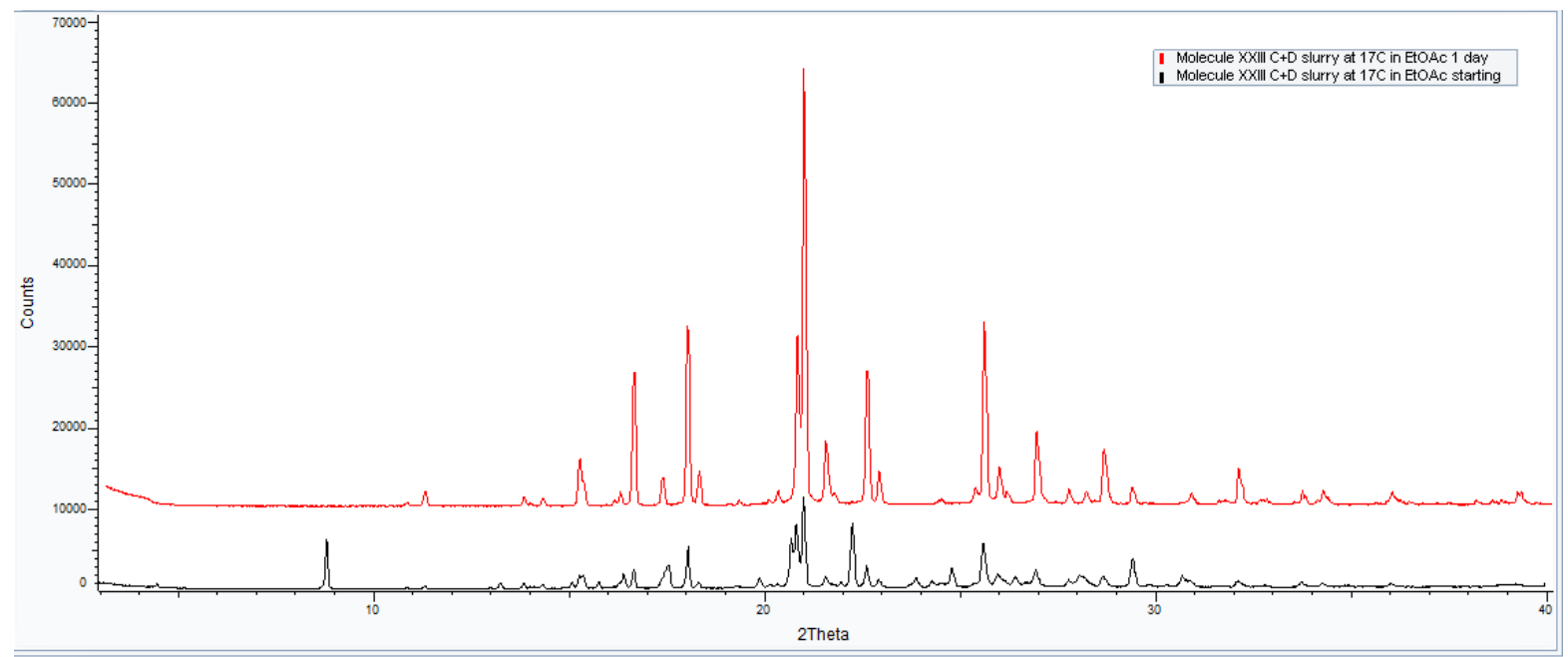

Figure S 48. Overlay PXRD patterns of Molecule XXIII Form C and D slurry in ethyl acetate at $17^{\circ} \mathrm{C}$ Table S 10. Slurry experiments of Molecule XXIII at $18^{\circ} \mathrm{C}(\mathrm{C} \rightarrow \mathrm{D} \rightarrow \mathrm{B} \rightarrow \mathrm{A})$

\begin{tabular}{|c|c|c|c|c|c|}
\hline \multirow{2}{*}{$\begin{array}{c}\text { Temperature, } \\
{ }^{\circ} \mathrm{C}\end{array}$} & \multirow{2}{*}{ Solvent } & \multicolumn{3}{|c|}{ PXRD } & \multirow{2}{*}{ Cascade } \\
\cline { 3 - 5 } & & starting & 1 day & 5 days & \\
\hline 18 & Ethyl acetate & $\mathrm{A}+\mathrm{B}$ & $\mathrm{A}$ & & $\mathrm{B} \rightarrow \mathrm{A}$ \\
\hline 18 & Ethyl acetate & $\mathrm{A}+\mathrm{D}$ & $\mathrm{A}$ & & $\mathrm{D} \rightarrow \mathrm{A}$ \\
\hline 18 & Ethyl acetate & $\mathrm{B}+\mathrm{D}$ & & $\mathrm{B}$ & $\mathrm{D} \rightarrow \mathrm{B}$ \\
\hline 18 & Ethyl acetate & $\mathrm{C}+\mathrm{D}$ & $\mathrm{D}$ & & $\mathrm{C} \rightarrow \mathrm{D}$ \\
\hline
\end{tabular}




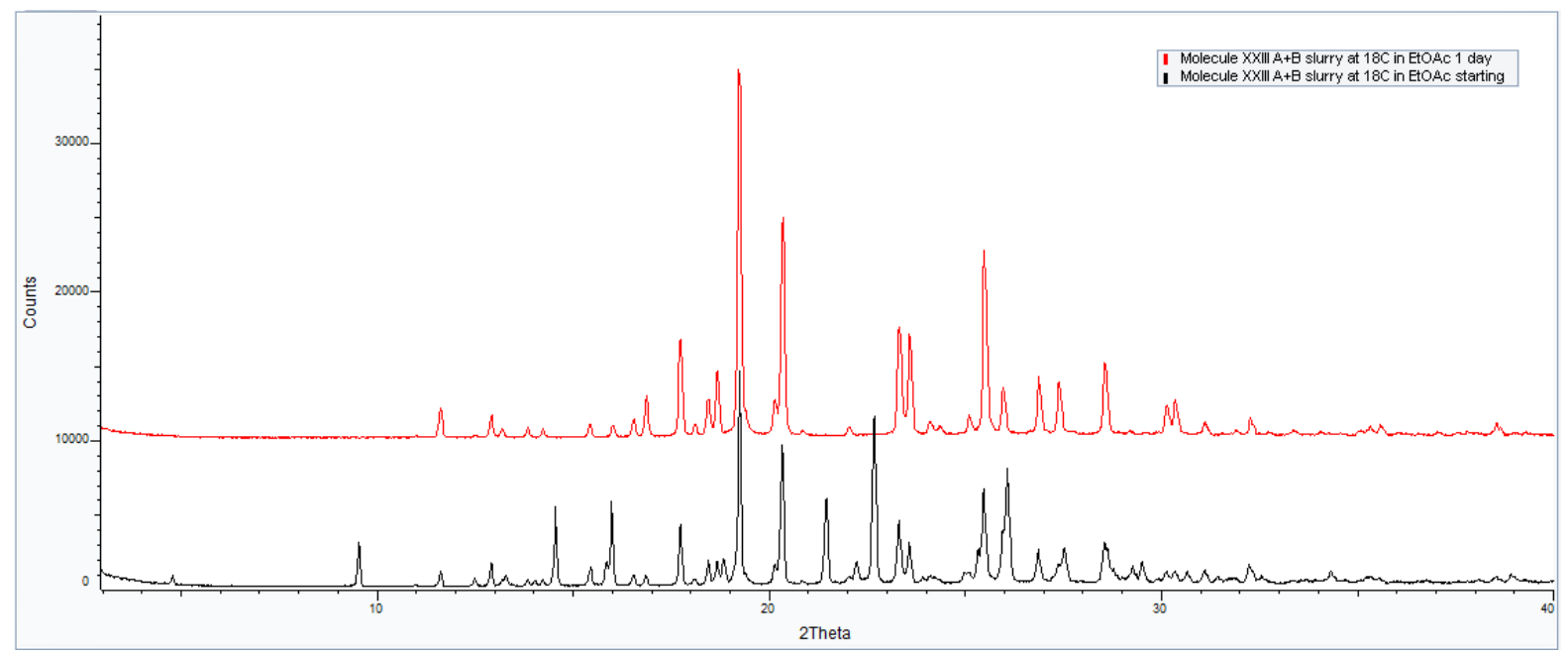

Figure S 49. Overlay PXRD patterns of Molecule XXIII Form A and B slurry in ethyl acetate at $18^{\circ} \mathrm{C}$

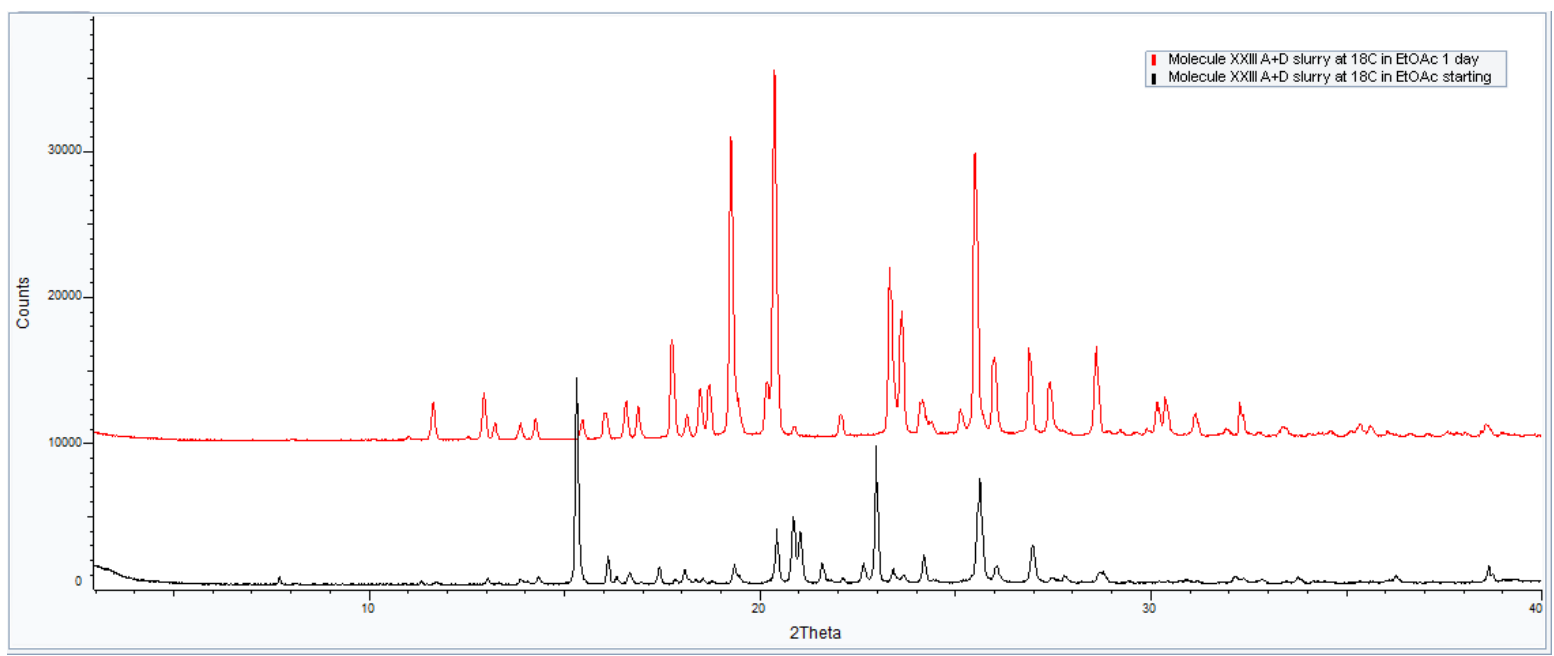

Figure S 50. Overlay PXRD patterns of Molecule XXIII Form A and D slurry in ethyl acetate at $18^{\circ} \mathrm{C}$

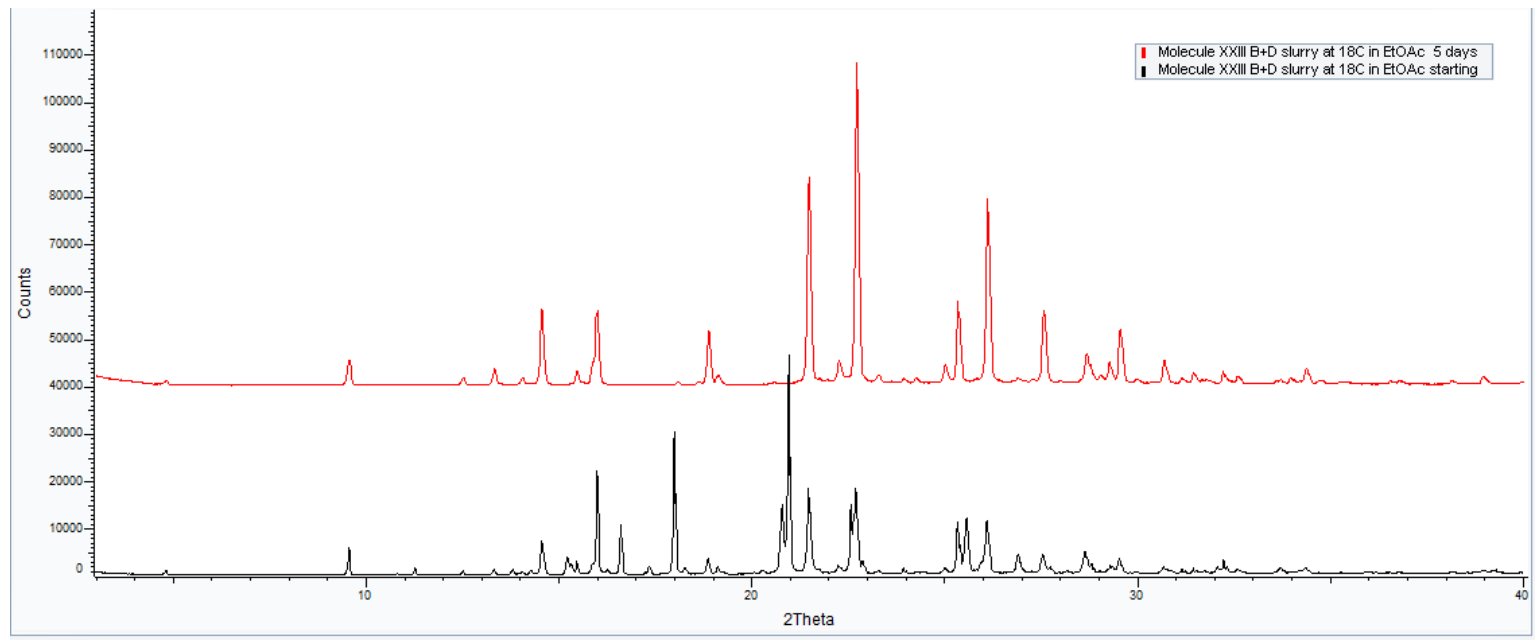

Figure S 51. Overlay PXRD patterns of Molecule XXIII Form B and D slurry in ethyl acetate at $18^{\circ} \mathrm{C}$ 


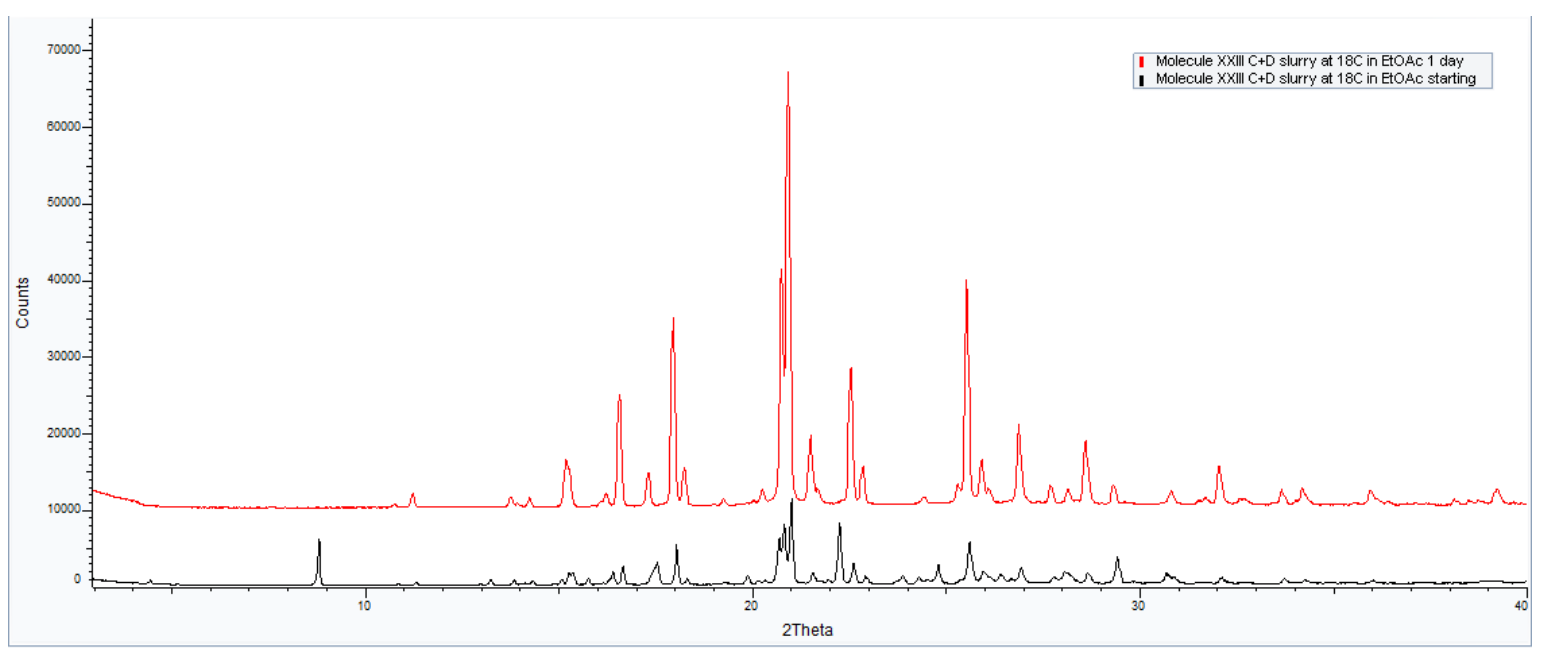

Figure S 52. Overlay PXRD patterns of Molecule XXIII Form C and D slurry in ethyl acetate at $18^{\circ} \mathrm{C}$

Table S 11. Slurry experiments of Molecule XXIII at $19^{\circ} \mathrm{C}(\mathrm{C} \rightarrow \mathrm{B} \rightarrow \mathrm{D} \rightarrow \mathrm{A})$

\begin{tabular}{|c|c|c|c|c|c|}
\hline \multirow{2}{*}{$\begin{array}{c}\text { Temperature, } \\
{ }^{\circ} \mathrm{C}\end{array}$} & \multirow{2}{*}{ Solvent } & \multicolumn{3}{|c|}{ PXRD } & \multirow{2}{*}{ Cascade } \\
\cline { 3 - 5 } & & starting & 1 day & 2 days & \\
\hline 19 & Ethyl acetate & $\mathrm{B}+\mathrm{C}$ & $\mathrm{B}$ & & $\mathrm{C} \rightarrow \mathrm{B}$ \\
\hline 19 & Ethyl acetate & $\mathrm{A}+\mathrm{B}$ & $\mathrm{A}$ & & $\mathrm{B} \rightarrow \mathrm{A}$ \\
\hline 19 & Ethyl acetate & $\mathrm{A}+\mathrm{D}$ & $\mathrm{A}+\mathrm{D}$ & $\mathrm{A}$ & $\mathrm{D} \rightarrow \mathrm{A}$ \\
\hline 19 & Ethyl acetate & $\mathrm{B}+\mathrm{D}$ & $\mathrm{D}$ & & $\mathrm{B} \rightarrow \mathrm{D}$ \\
\hline 19 & Ethyl acetate & $\mathrm{C}+\mathrm{D}$ & $\mathrm{D}$ & & $\mathrm{C} \rightarrow \mathrm{D}$ \\
\hline
\end{tabular}

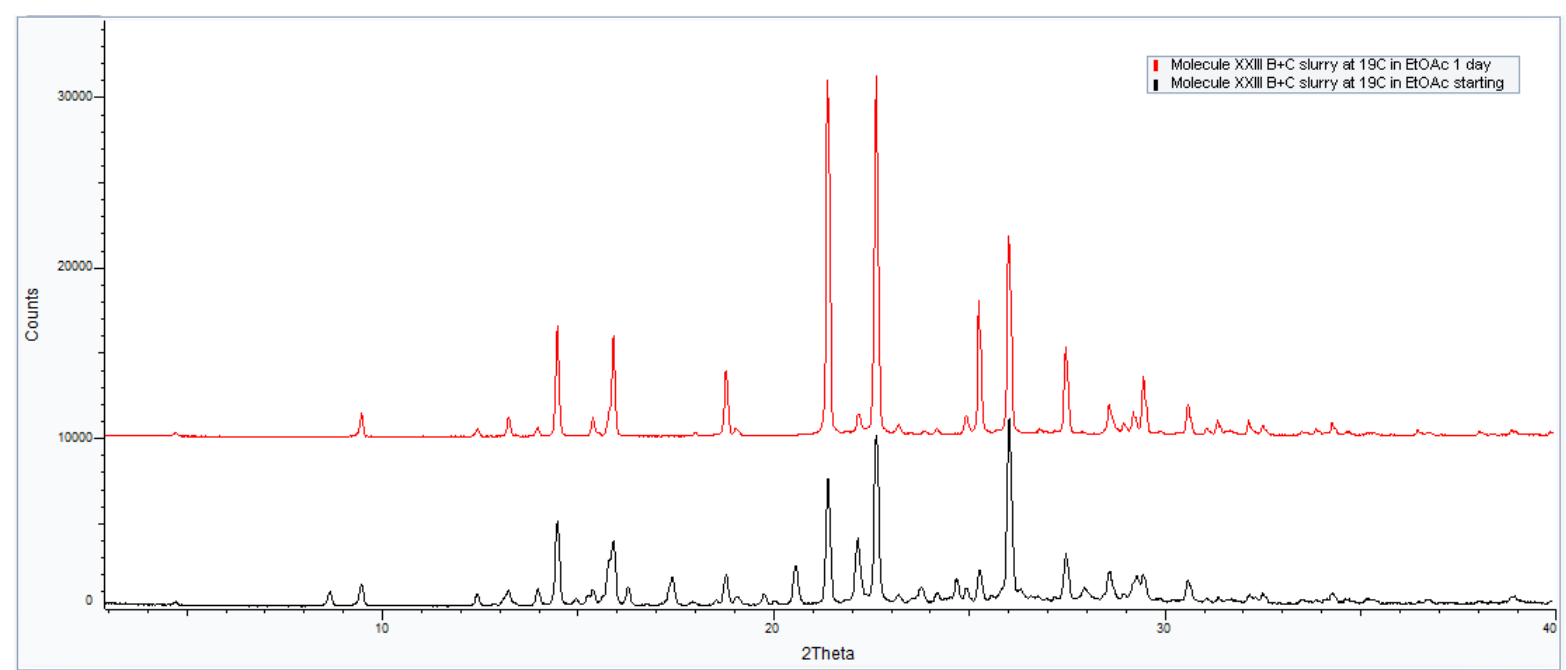

Figure S 53. Overlay PXRD patterns of Molecule XXIII Form B and C slurry in ethyl acetate at $19^{\circ} \mathrm{C}$ 


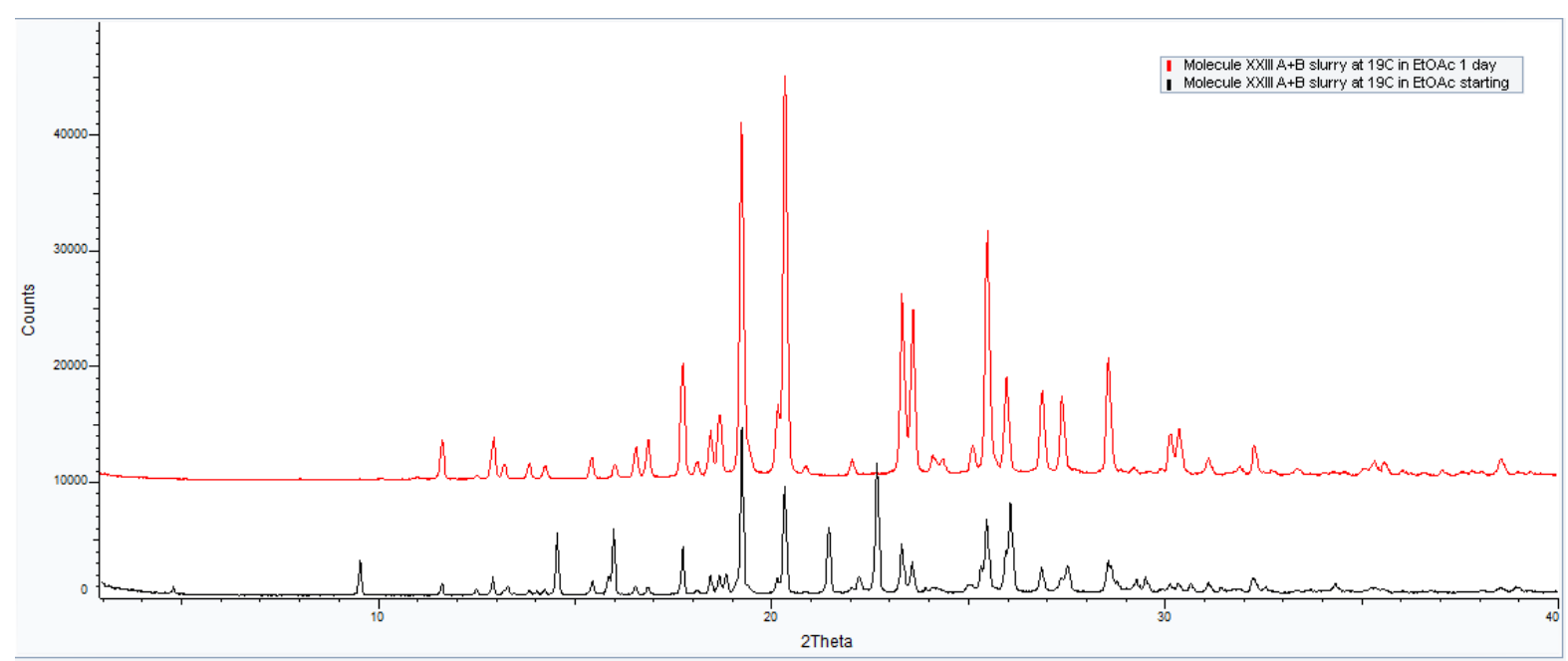

Figure S 54. Overlay PXRD patterns of Molecule XXIII Form A and B slurry in ethyl acetate at $19^{\circ} \mathrm{C}$

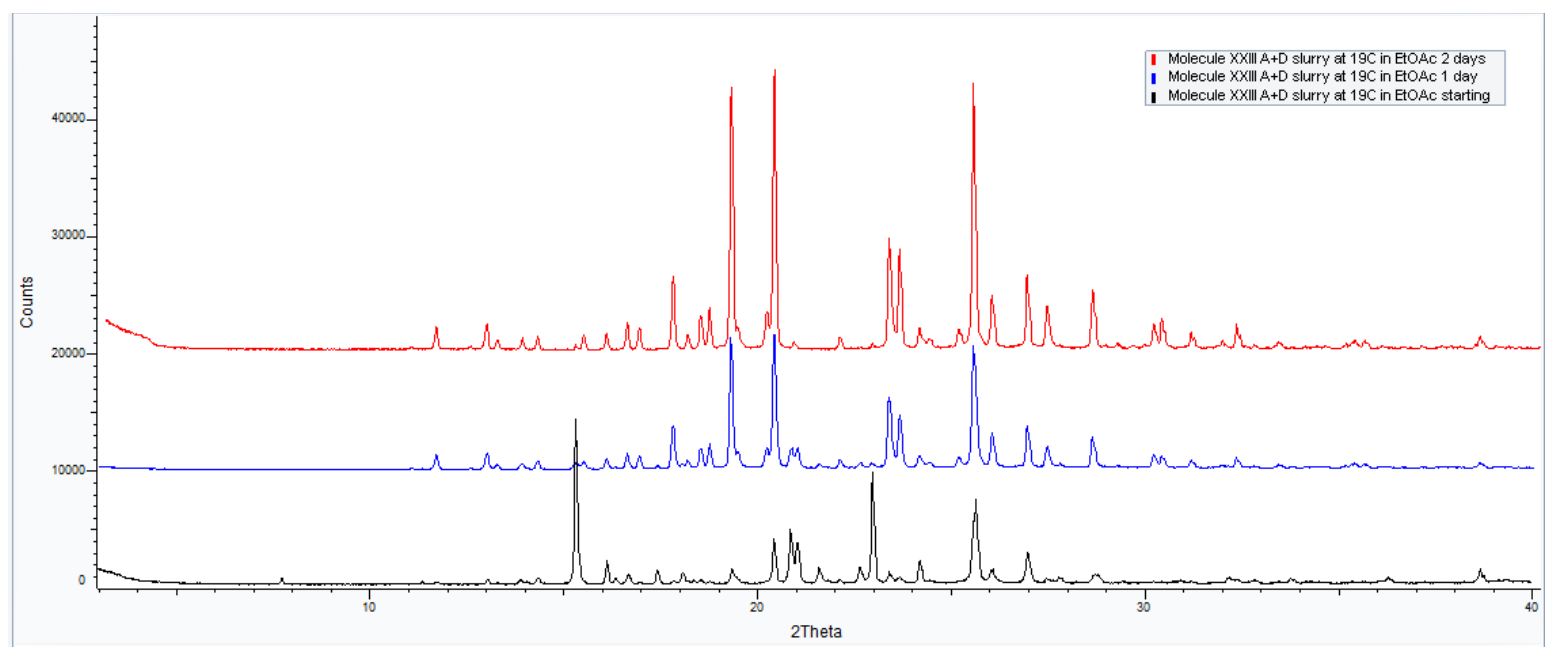

Figure S 55. Overlay PXRD patterns of Molecule XXIII Form A and D slurry in ethyl acetate at $19^{\circ} \mathrm{C}$

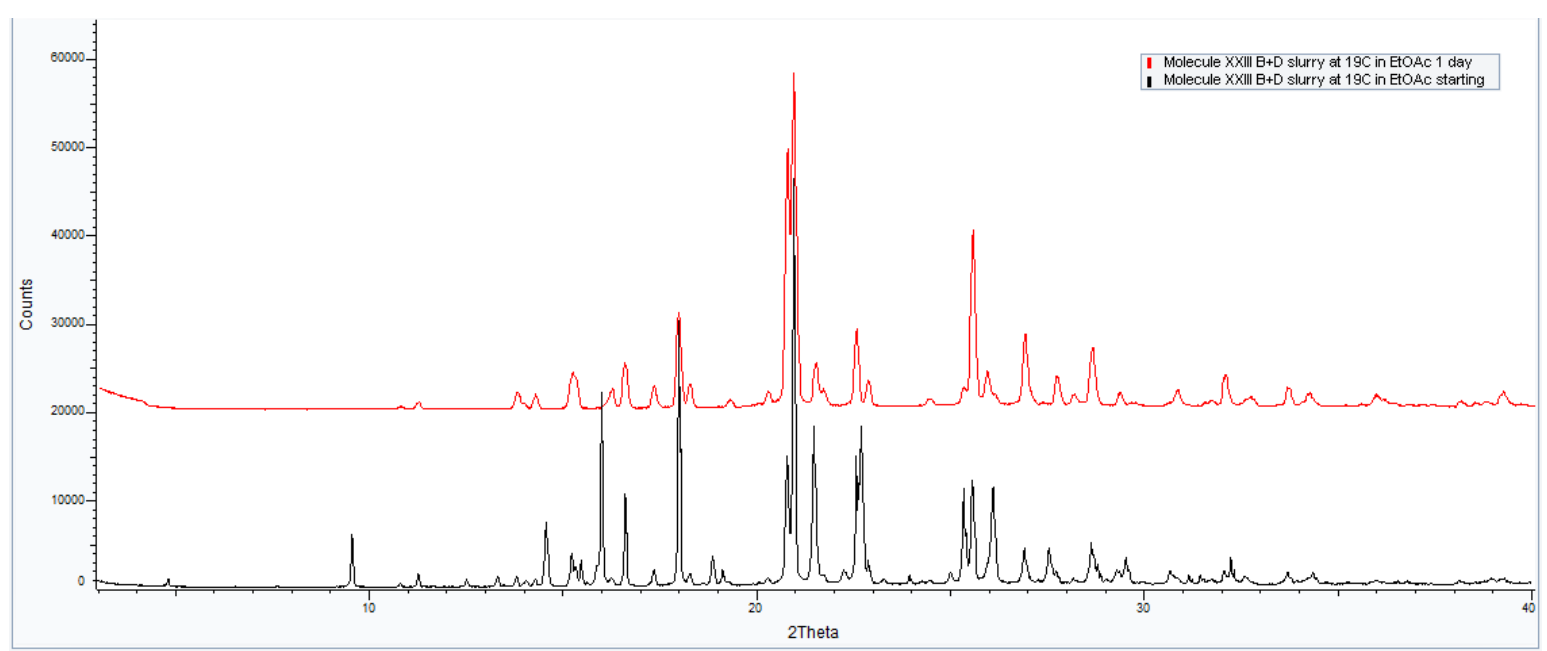

Figure S 56. Overlay PXRD patterns of Molecule XXIII Form B and D slurry in ethyl acetate at $19^{\circ} \mathrm{C}$ 


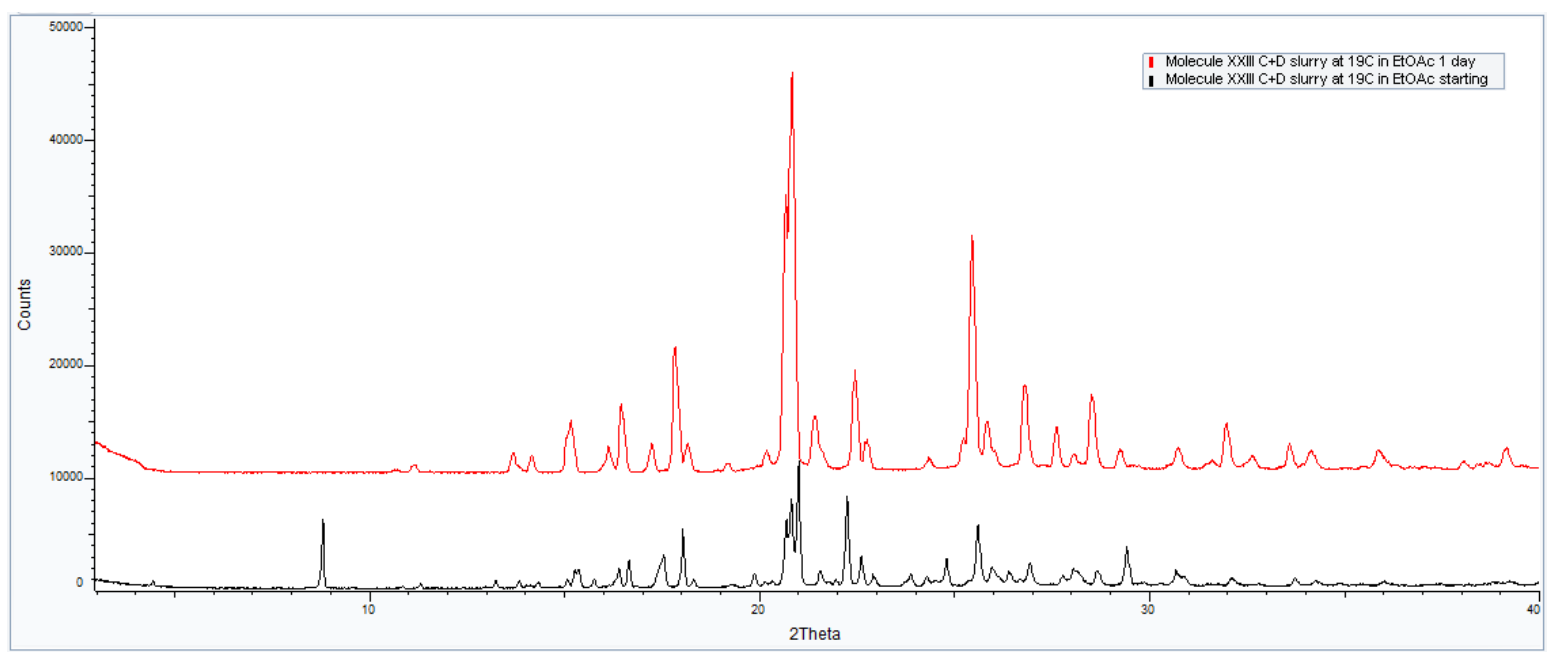

Figure S 57. Overlay PXRD patterns of Molecule XXIII Form C and D slurry in ethyl acetate at $19^{\circ} \mathrm{C}$

Table S 12. Slurry experiments of Molecule XXIII at $20^{\circ} \mathrm{C}(\mathrm{C} \rightarrow \mathrm{B} \rightarrow \mathrm{D} \rightarrow \mathrm{A})$

\begin{tabular}{|c|c|c|c|c|c|}
\hline \multirow{2}{*}{$\begin{array}{c}\text { Temperature, } \\
{ }^{\circ} \mathrm{C}\end{array}$} & \multirow{2}{*}{ Solvent } & \multicolumn{3}{|c|}{ PXRD } & \multirow{2}{*}{ Cascade } \\
\cline { 3 - 5 } & & starting & 1 day & 3 days & \\
\hline 20 & Ethyl acetate & B+C & B & & C $\rightarrow \mathrm{B}$ \\
\hline 20 & Ethyl acetate & B+D & D & & B $\rightarrow \mathrm{D}$ \\
\hline 20 & 2-methyl THF & A+D & & A & D $\rightarrow \mathrm{A}$ \\
\hline
\end{tabular}

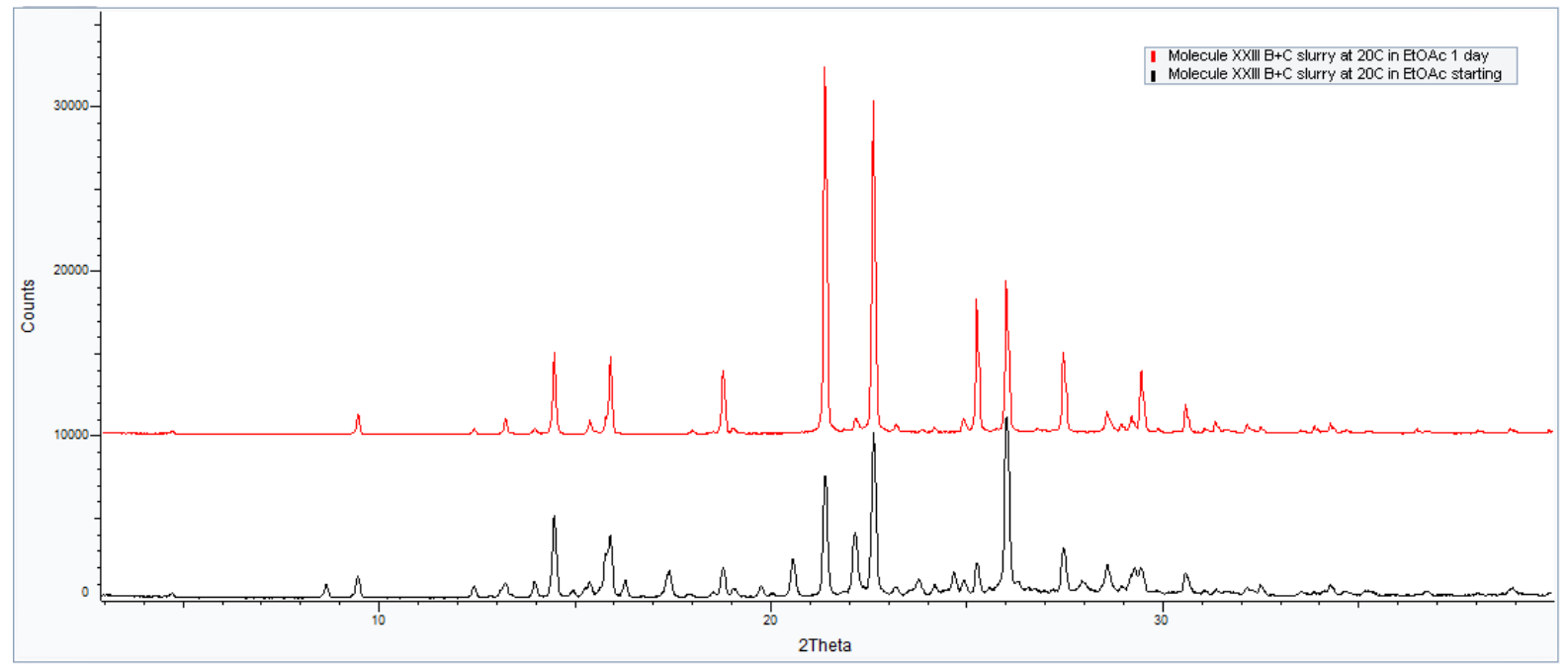

Figure S 58. Overlay PXRD patterns of Molecule XXIII Form B and C slurry in ethyl acetate at $20^{\circ} \mathrm{C}$ 


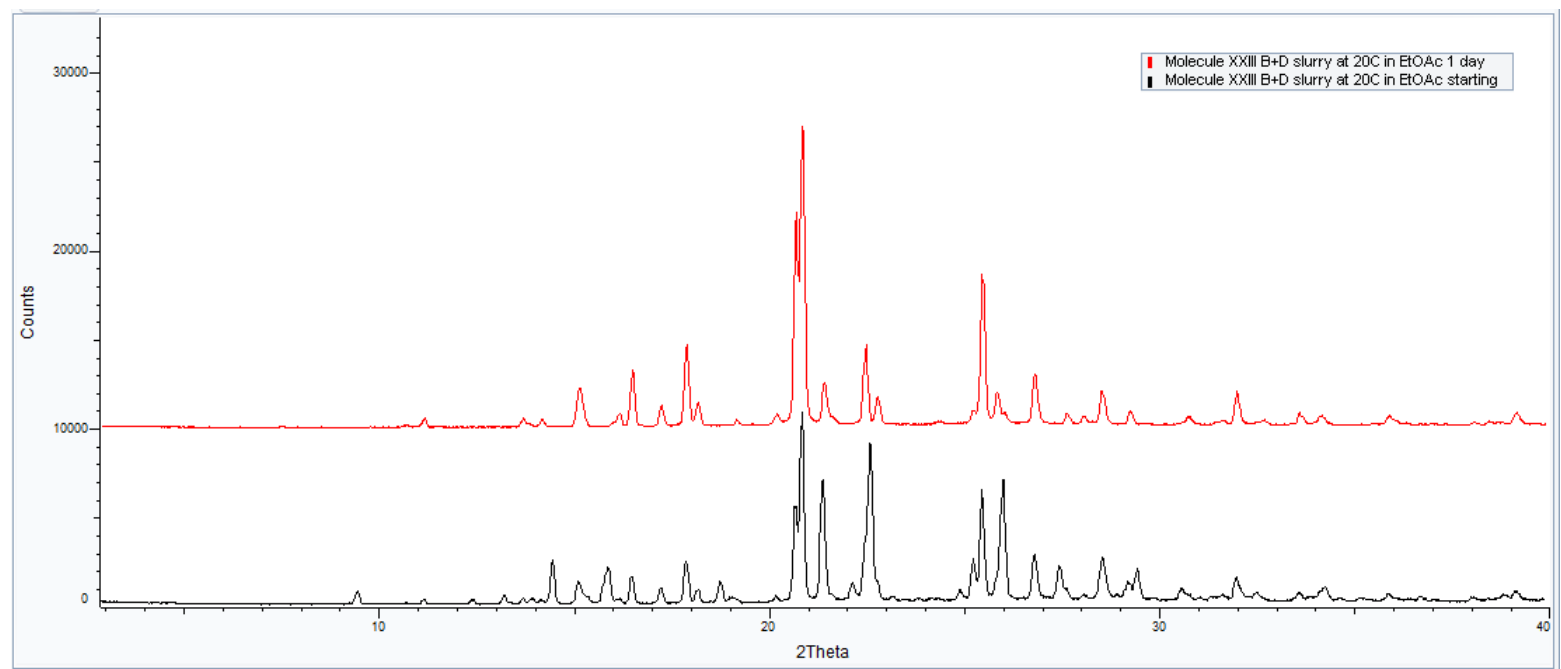

Figure S 59. Overlay PXRD patterns of Molecule XXIII Form B and D slurry in ethyl acetate at $20^{\circ} \mathrm{C}$

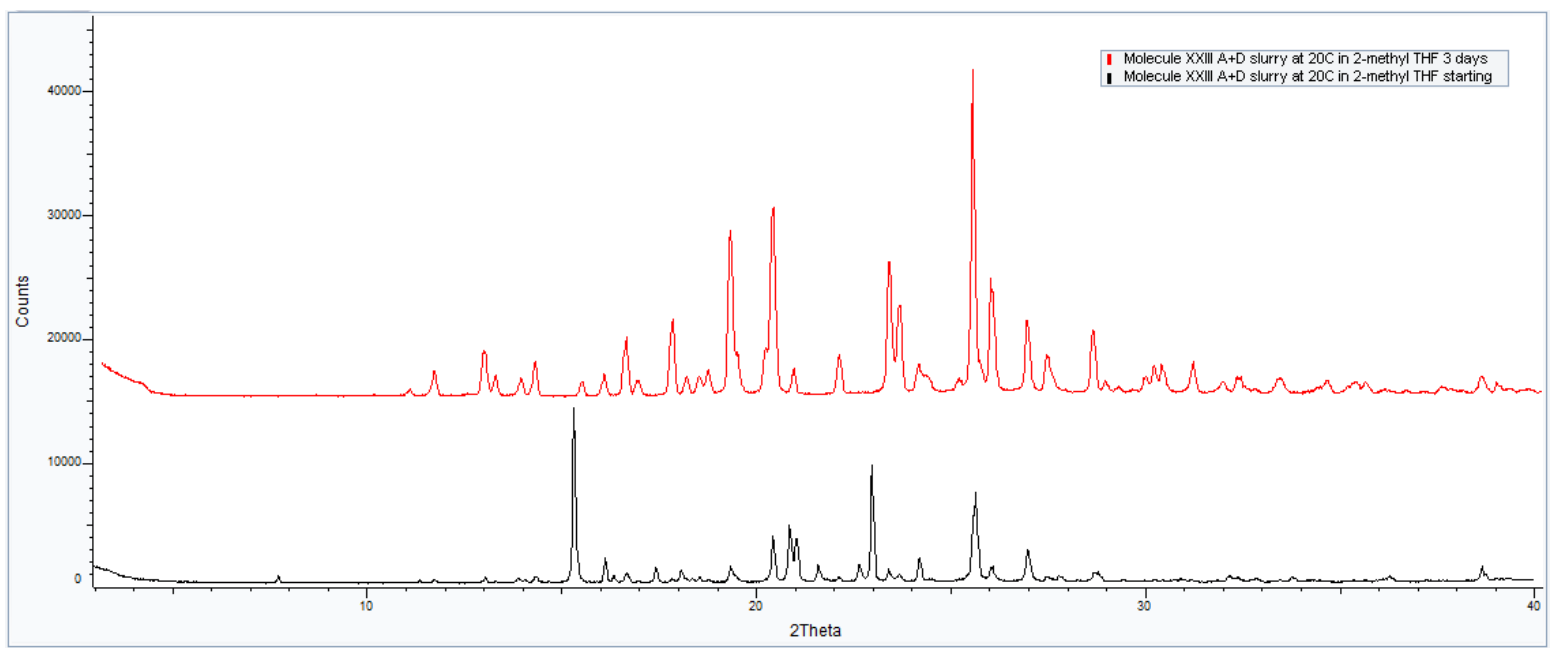

Figure S 60. Overlay PXRD patterns of Molecule XXIII Form A and D slurry in 2-methyl THF at $20^{\circ} \mathrm{C}$

Table S 13. Slurry experiments of Molecule XXIII at $21^{\circ} \mathrm{C}(\mathrm{C} \rightarrow \mathrm{B} \rightarrow \mathrm{D} \rightarrow \mathrm{A})$

\begin{tabular}{|c|c|c|c|c|c|}
\hline \multirow{2}{*}{$\begin{array}{c}\text { Temperature, } \\
{ }^{\circ} \mathrm{C}\end{array}$} & Solvent & \multicolumn{3}{|c|}{ PXRD } & \multirow{2}{*}{ Cascade } \\
\cline { 3 - 6 } & & starting & 1 day & 7 days & \\
\hline 21 & Ethyl acetate & $\mathrm{B}+\mathrm{C}$ & $\mathrm{B}$ & & $\mathrm{C} \rightarrow \mathrm{B}$ \\
\hline 21 & Ethyl acetate & $\mathrm{B}+\mathrm{D}$ & $\mathrm{D}$ & & $\mathrm{B} \rightarrow \mathrm{D}$ \\
\hline 21 & 2-methyl THF & $\mathrm{A}+\mathrm{D}$ & & $\mathrm{A}$ & $\mathrm{D} \rightarrow \mathrm{A}$ \\
\hline
\end{tabular}


Five Degrees of Separation: Characterization and Temperature Stability Profiles for the Polymorphs of PD-0118057 (Molecule XXIII)- Supporting Information

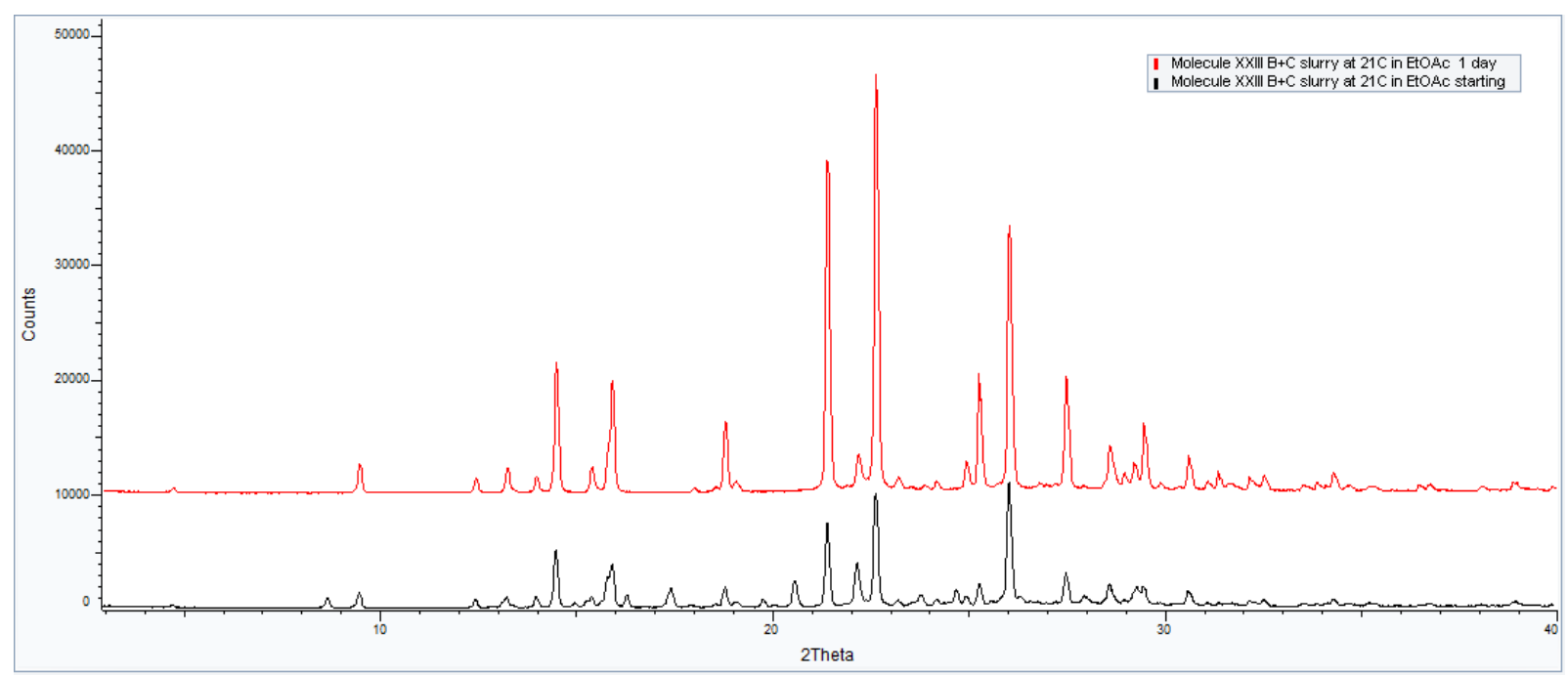

Figure S 61. Overlay PXRD patterns of Molecule XXIII Form B and C slurry in ethyl acetate at $21^{\circ} \mathrm{C}$

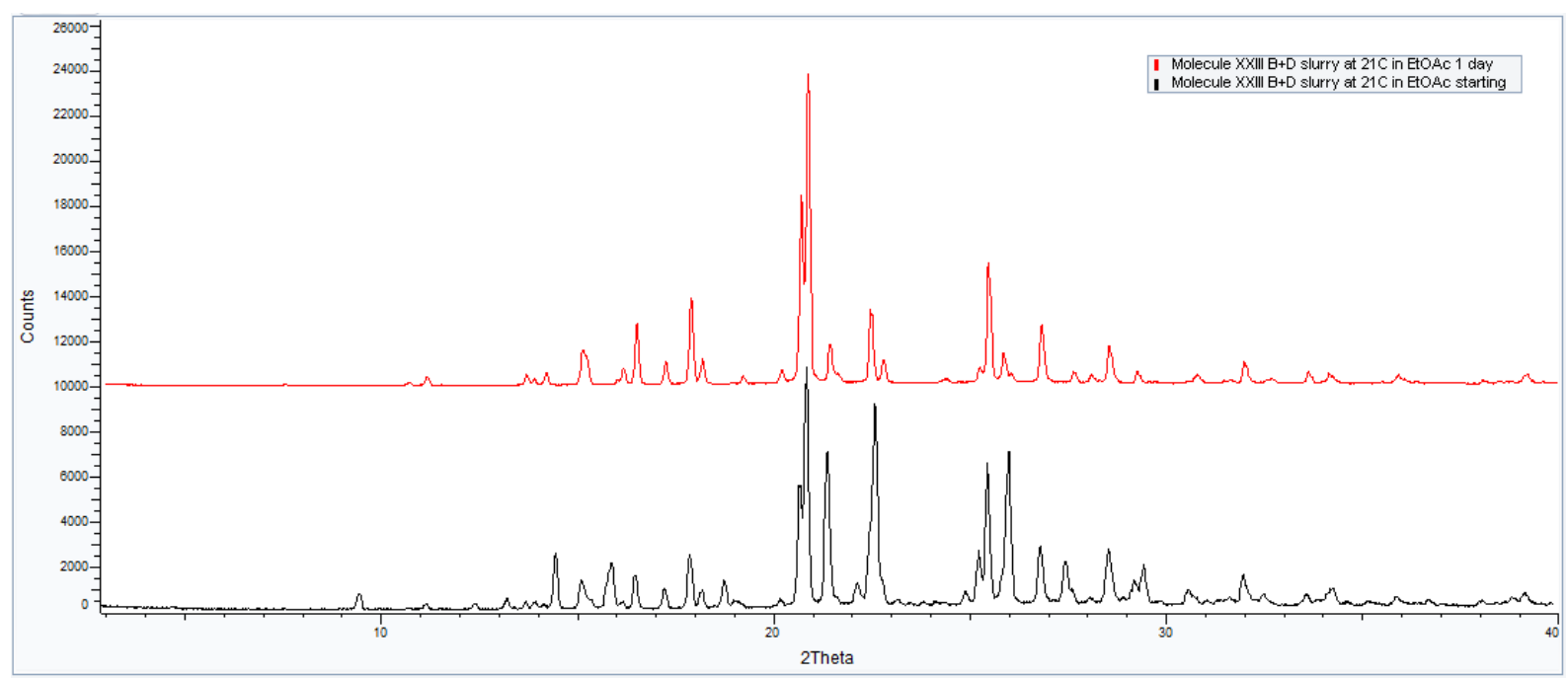

Figure S 62. Overlay PXRD patterns of Molecule XXIII Form B and D slurry in ethyl acetate at $21^{\circ} \mathrm{C}$ 


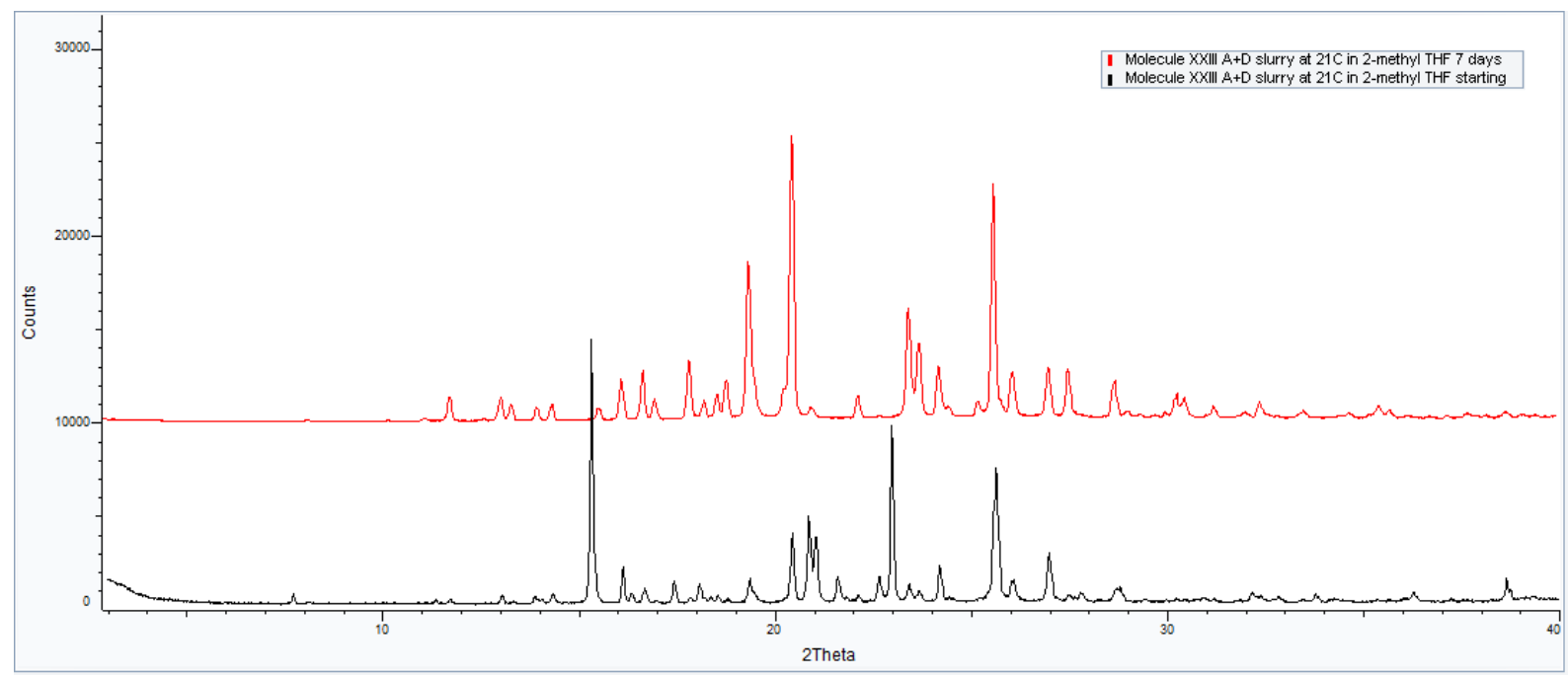

Figure S 63. Overlay PXRD patterns of Molecule XXIII Form A and D slurry in 2-methyl THF at $21^{\circ} \mathrm{C}$

Table S 14. Slurry experiments of Molecule XXIII at $22^{\circ} \mathrm{C}(\mathrm{C} \rightarrow \mathrm{B} \rightarrow \mathrm{A} \rightarrow \mathrm{D})$

\begin{tabular}{|c|c|c|c|c|c|}
\hline \multirow{2}{*}{$\begin{array}{c}\text { Temperature, } \\
{ }^{\circ} \mathrm{C}\end{array}$} & \multirow{2}{*}{ Solvent } & \multicolumn{3}{|c|}{ PXRD } & \multirow{2}{*}{ Cascade } \\
\cline { 3 - 5 } & & starting & 1 day & 10 days & \\
\hline 22 & Ethyl acetate & $\mathrm{B}+\mathrm{C}$ & $\mathrm{B}$ & & $\mathrm{C} \rightarrow \mathrm{B}$ \\
\hline 22 & Ethyl acetate & $\mathrm{A}+\mathrm{B}$ & $\mathrm{A}$ & & $\mathrm{B} \rightarrow \mathrm{A}$ \\
\hline 22 & 2-methyl THF & $\mathrm{A}+\mathrm{D}$ & & $\mathrm{D}+$ some $\mathrm{A}$ & $\mathrm{A} \rightarrow \mathrm{D}$ \\
\hline
\end{tabular}

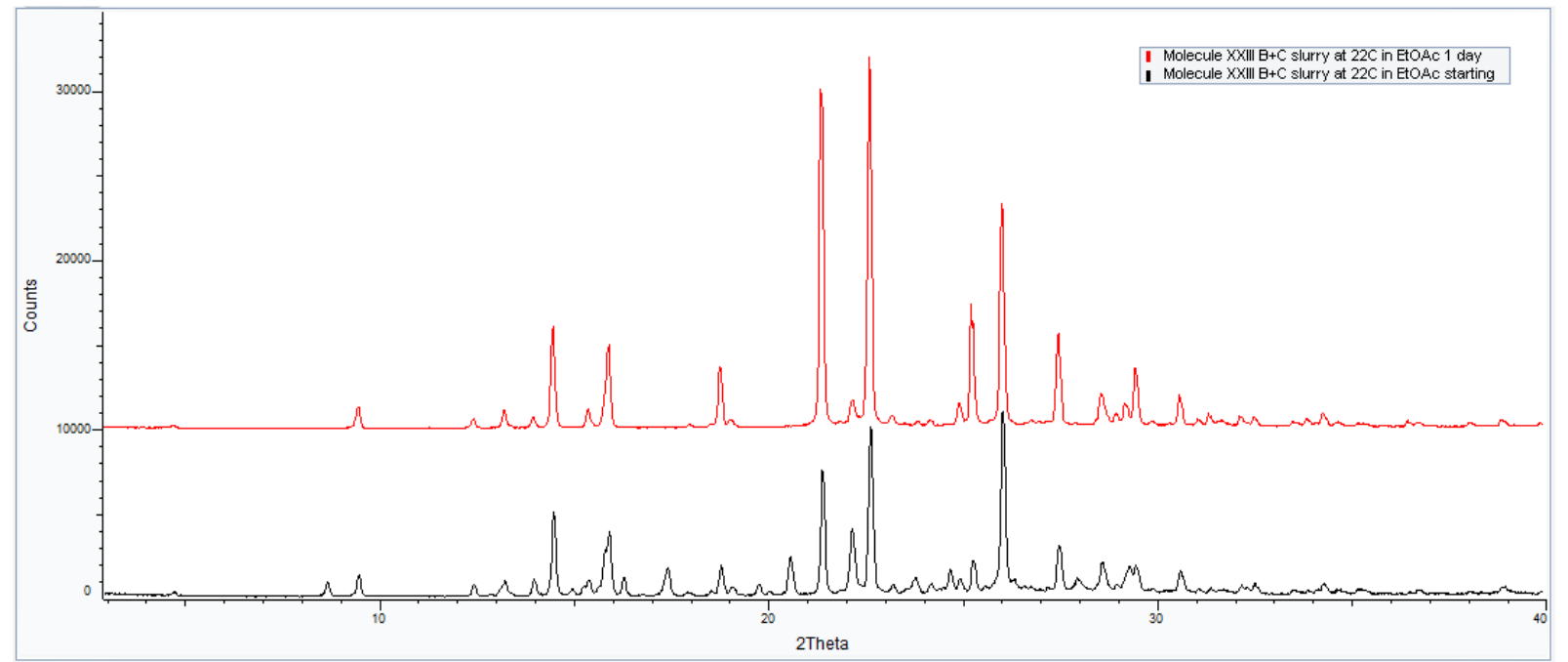

Figure S 64. Overlay PXRD patterns of Molecule XXIII Form B and C slurry in ethyl acetate at $22^{\circ} \mathrm{C}$ 


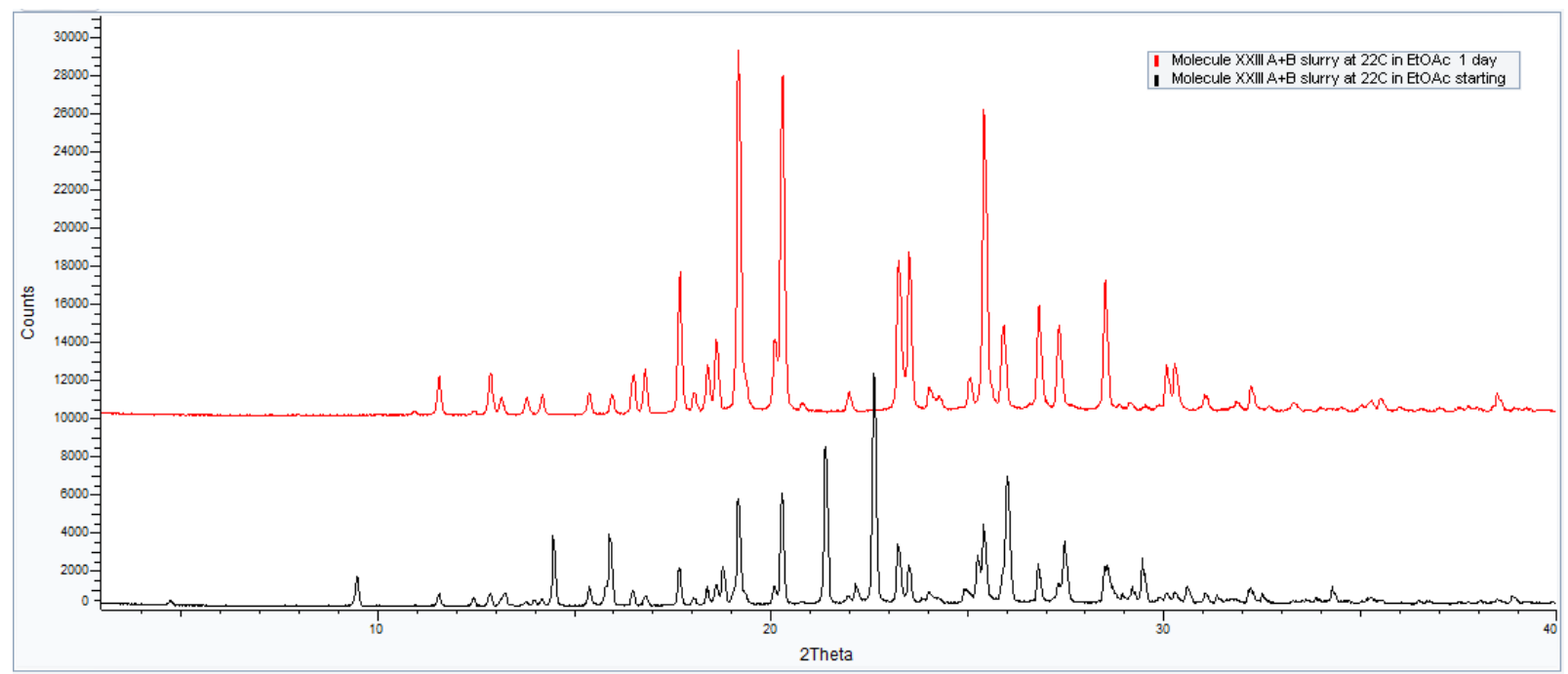

Figure S 65. Overlay PXRD patterns of Molecule XXIII Form A and B slurry in ethyl acetate at $22^{\circ} \mathrm{C}$

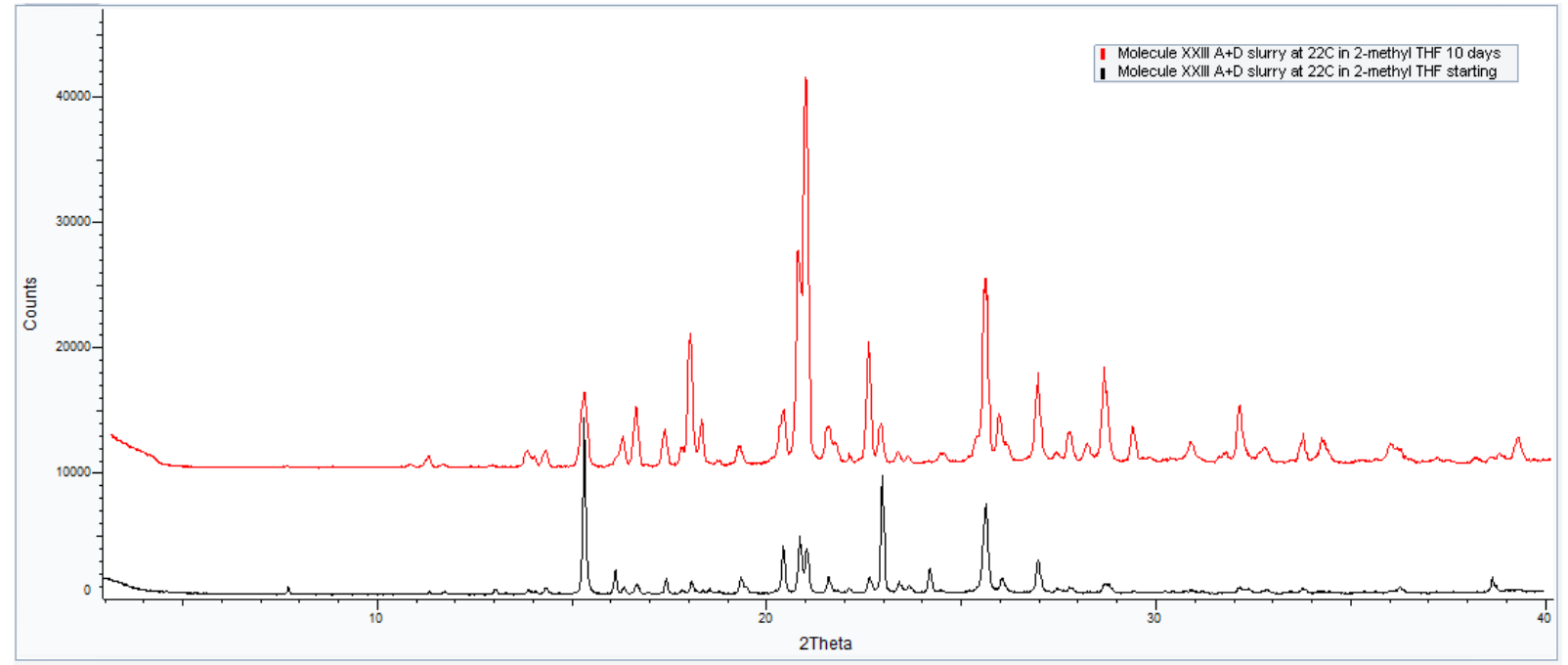

Figure S 66. Overlay PXRD patterns of Molecule XXIII Form A and D slurry in 2-methyl THF at $22^{\circ} \mathrm{C}$

Table S 15 . Slurry experiments of Molecule XXIII at $23^{\circ} \mathrm{C}(\mathrm{C} \rightarrow \mathrm{B} \rightarrow \mathrm{A} \rightarrow \mathrm{D})$

\begin{tabular}{|c|c|c|c|c|c|}
\hline \multirow{2}{*}{$\begin{array}{c}\text { Temperature, } \\
{ }^{\circ} \mathrm{C}\end{array}$} & \multirow{2}{*}{ Solvent } & \multicolumn{3}{|c|}{ PXRD } & \multirow{2}{*}{ Cascade } \\
\cline { 3 - 5 } & & starting & 13 hours & 3 days & \\
\hline 23 & Ethyl acetate & $\mathrm{B}+\mathrm{C}$ & $\mathrm{B}$ & & $\mathrm{C} \rightarrow \mathrm{B}$ \\
\hline 23 & Ethyl acetate & $\mathrm{A}+\mathrm{B}$ & $\mathrm{A}$ & & $\mathrm{B} \rightarrow \mathrm{A}$ \\
\hline 23 & 2-methyl THF & $\mathrm{A}+\mathrm{D}$ & & $\mathrm{D}$ & $\mathrm{A} \rightarrow \mathrm{D}$ \\
\hline
\end{tabular}




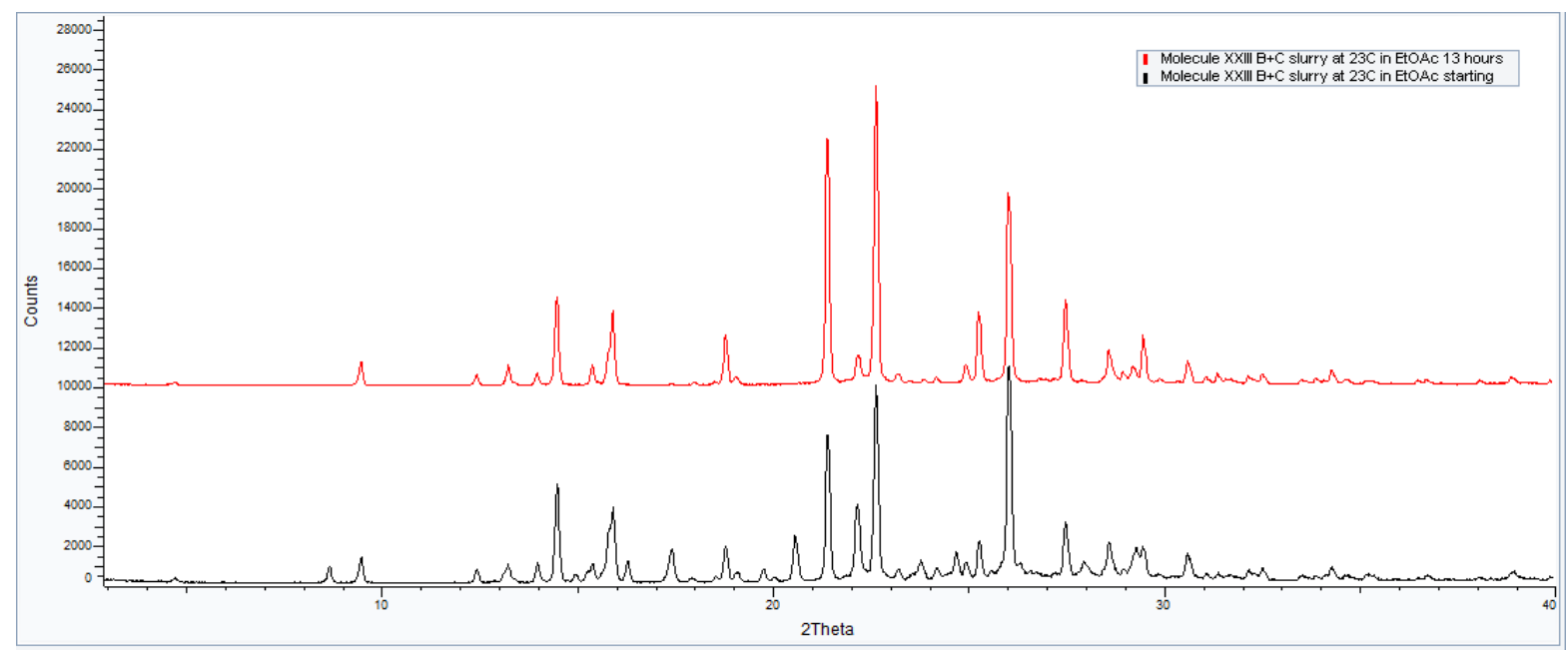

Figure S 67. Overlay PXRD patterns of Molecule XXIII Form B and C slurry in ethyl acetate at $23^{\circ} \mathrm{C}$

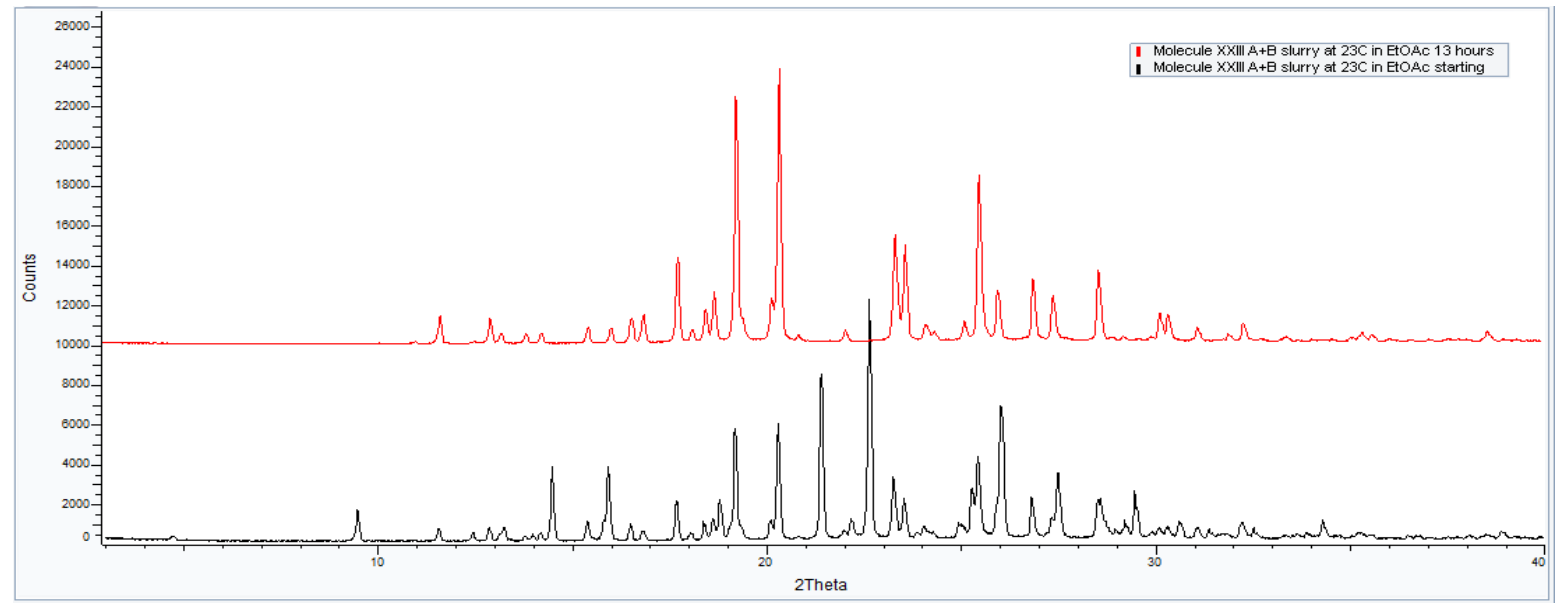

Figure S 68. Overlay PXRD patterns of Molecule XXIII Form A and B slurry in ethyl acetate at $23^{\circ} \mathrm{C}$

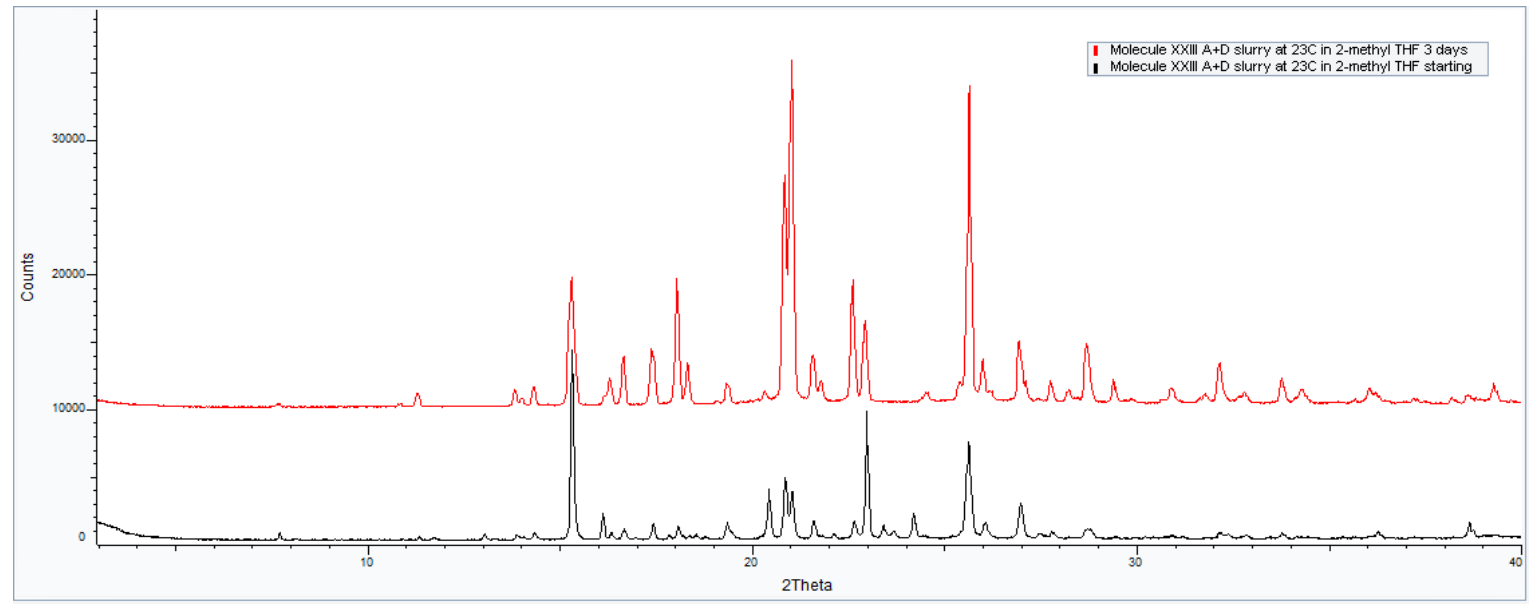

Figure S 69. Overlay PXRD pattern of Molecule XXIII Form A and D slurry in 2-methyl THF at $23^{\circ} \mathrm{C}$ 
Table S 16. Slurry experiments of Molecule XXIII at $40^{\circ} \mathrm{C}(\mathrm{C} \rightarrow \mathrm{B} \rightarrow \mathrm{A} \rightarrow \mathrm{D})$

\begin{tabular}{|c|c|c|c|c|c|c|}
\hline \multirow{2}{*}{$\begin{array}{c}\text { Temperature, } \\
{ }^{\circ} \mathrm{C}\end{array}$} & \multirow{2}{*}{ Solvent } & \multicolumn{4}{|c|}{ PXRD } & \multirow{2}{*}{ Cascade } \\
\cline { 3 - 6 } & & starting & 2 hours & 3 hours & 5 hours & \\
\hline 40 & Isopropanol & $\mathrm{A}+\mathrm{B}$ & & & $\mathrm{A}$ & $\mathrm{B} \rightarrow \mathrm{A}$ \\
\hline 40 & Isopropanol & $\mathrm{A}+\mathrm{D}$ & & & $\mathrm{D}$ & $\mathrm{A} \rightarrow \mathrm{D}$ \\
\hline 40 & Ethanol & $\mathrm{B}+\mathrm{C}$ & $\mathrm{B}+$ little C & $\mathrm{D}$ & & $\mathrm{C} \rightarrow \mathrm{B} \rightarrow \mathrm{D}$ \\
\hline
\end{tabular}

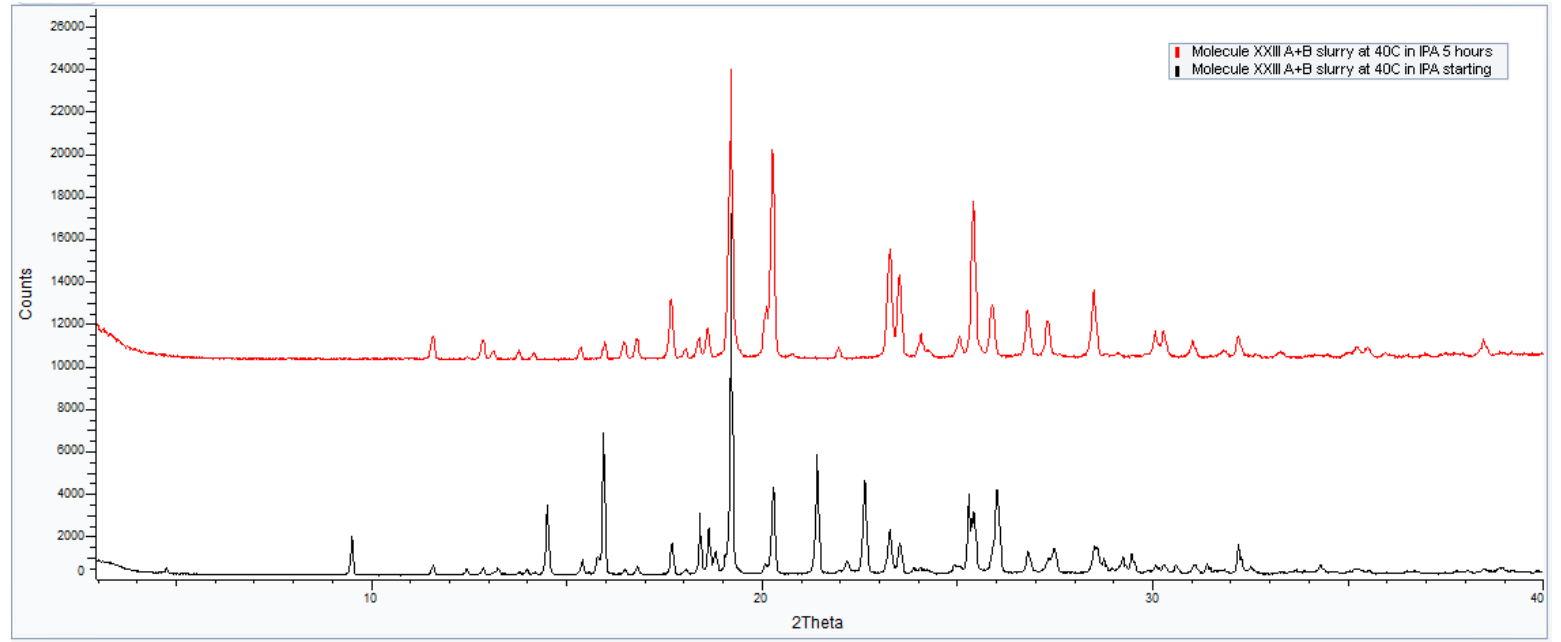

Figure S 70. Overlay PXRD patterns of Molecule XXIII Form A and B slurry in isopropanol at $40^{\circ} \mathrm{C}$

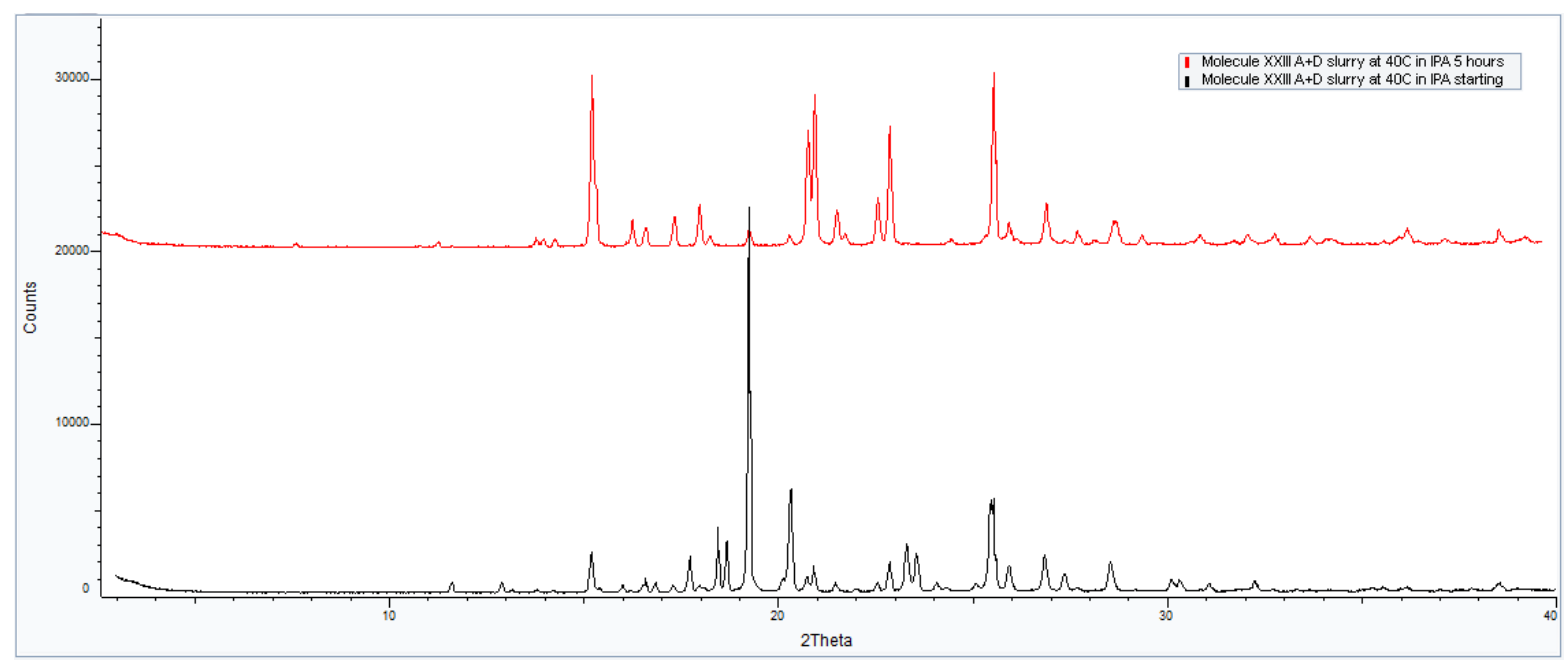

Figure S 71. Overlay PXRD patterns of Molecule XXIII Form A and D slurry in isopropanol at $40^{\circ} \mathrm{C}$ 
Five Degrees of Separation: Characterization and Temperature Stability Profiles for the Polymorphs of PD-0118057 (Molecule XXIII)- Supporting Information

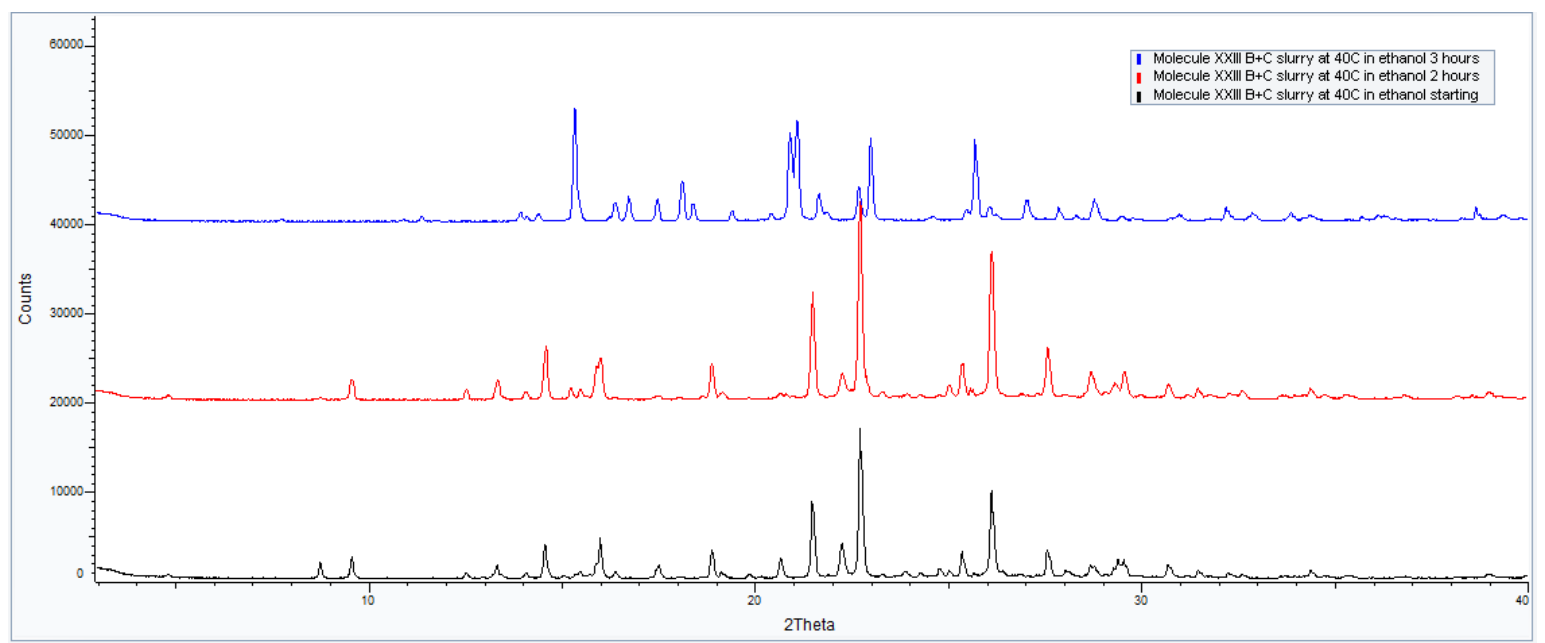

Figure S 72. Overlay PXRD patterns of Molecule XXIII Form B and C slurry in ethanol at $40^{\circ} \mathrm{C}$

Table S 17. Slurry experiments of Molecule XXIII Form A and Form D at $70^{\circ} \mathrm{C}$ and $96^{\circ} \mathrm{C}$

\begin{tabular}{|c|c|c|c|c|c|}
\hline \multirow{2}{*}{$\begin{array}{c}\text { Temperature, } \\
{ }^{\circ} \mathrm{C}\end{array}$} & \multirow{2}{*}{ Solvent } & \multicolumn{4}{|c|}{ PXRD } \\
\cline { 3 - 6 } & & starting & 2 days & 8 days & 14 days \\
\hline 70 & 2-propanol & $\mathrm{A}+\mathrm{D}$ & $\mathrm{D}$ & $\mathrm{D}$ & $\mathrm{D}$ \\
\hline 70 & cyclohexane & $\mathrm{A}+\mathrm{D}$ & $\mathrm{D}$ & $\mathrm{D}$ & $\mathrm{D}$ \\
\hline 96 & toluene & $\mathrm{A}+\mathrm{D}$ & $\mathrm{D}$ & $\mathrm{D}$ & \\
\hline 96 & cumene & $\mathrm{A}+\mathrm{D}$ & $\mathrm{D}$ & $\mathrm{D}$ & $\mathrm{D}$ \\
\hline
\end{tabular}

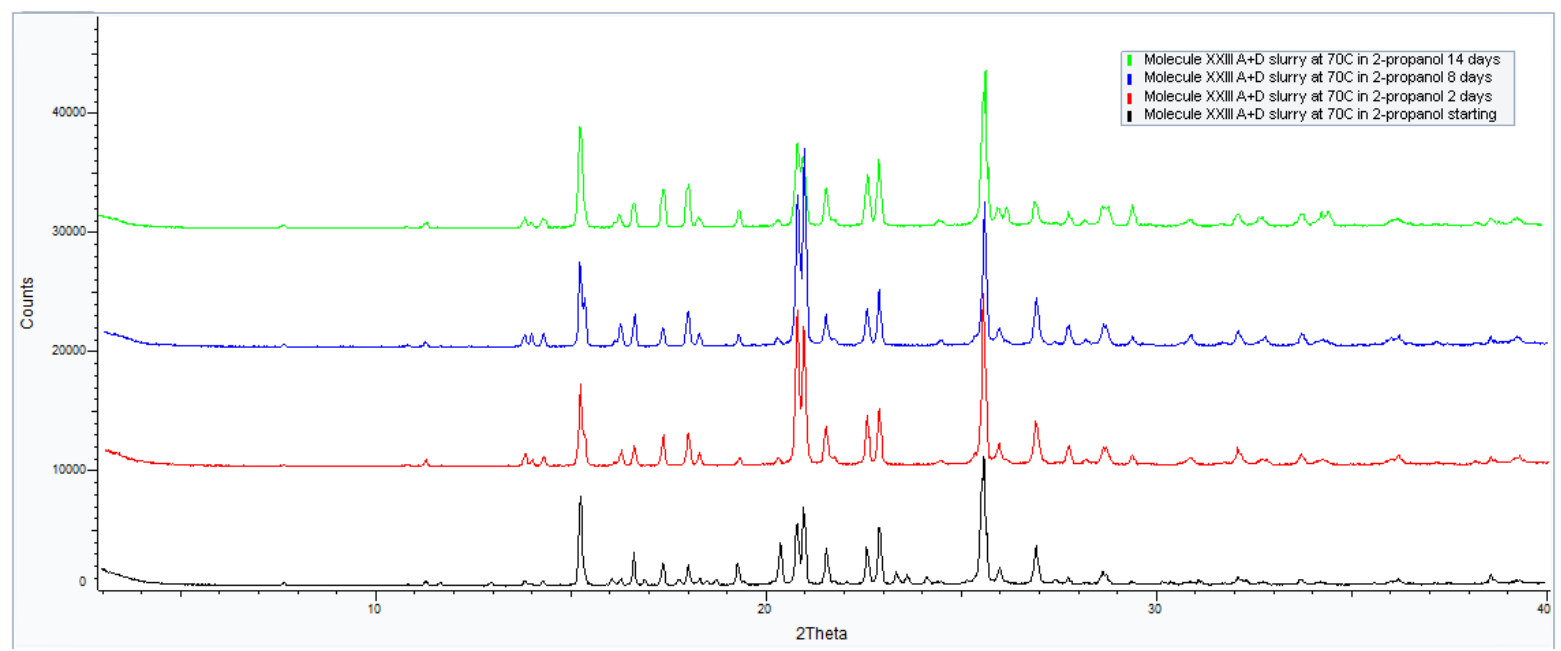

Figure S 73. Overlay PXRD patterns of Molecule XXIII Form A and D slurry in 2-propanol at $70^{\circ} \mathrm{C}$ 


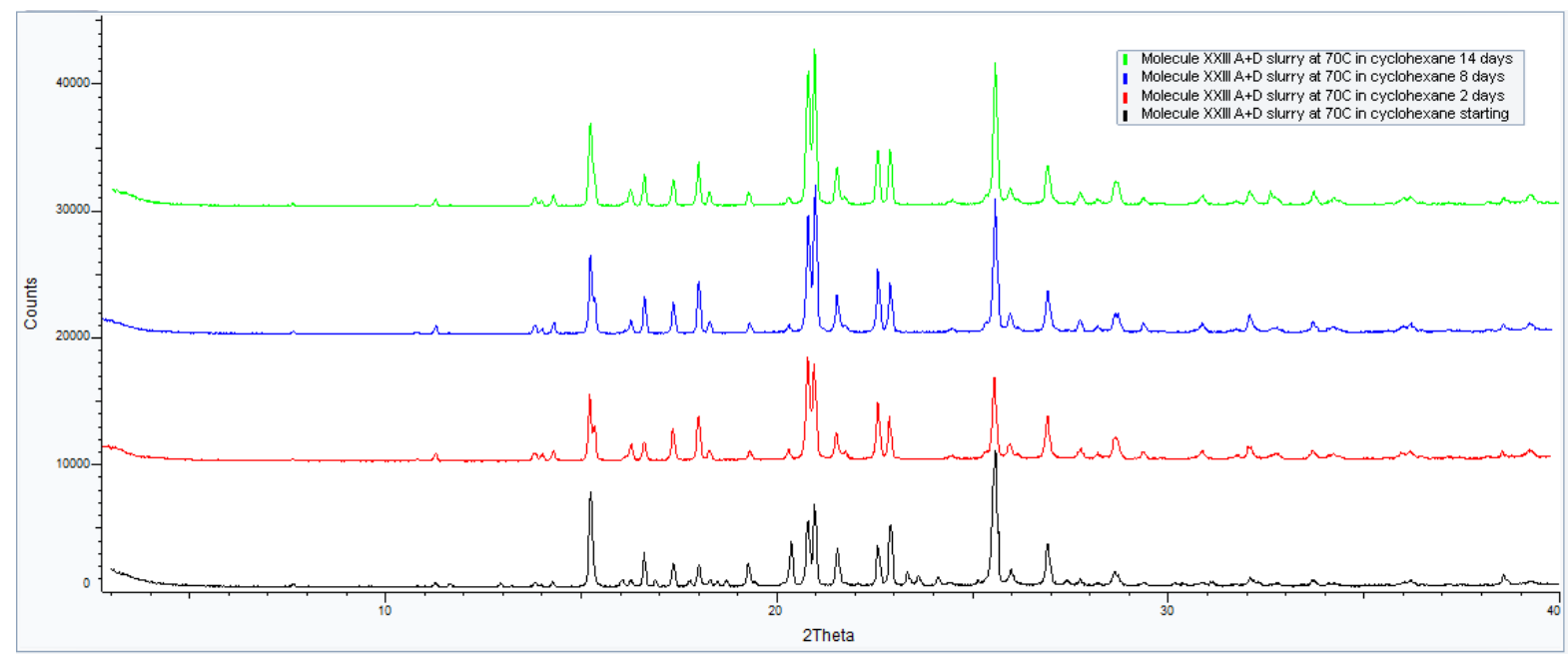

Figure S 74. Overlay PXRD patterns of Molecule XXIII Form A and D slurry in cyclohexane at $70^{\circ} \mathrm{C}$

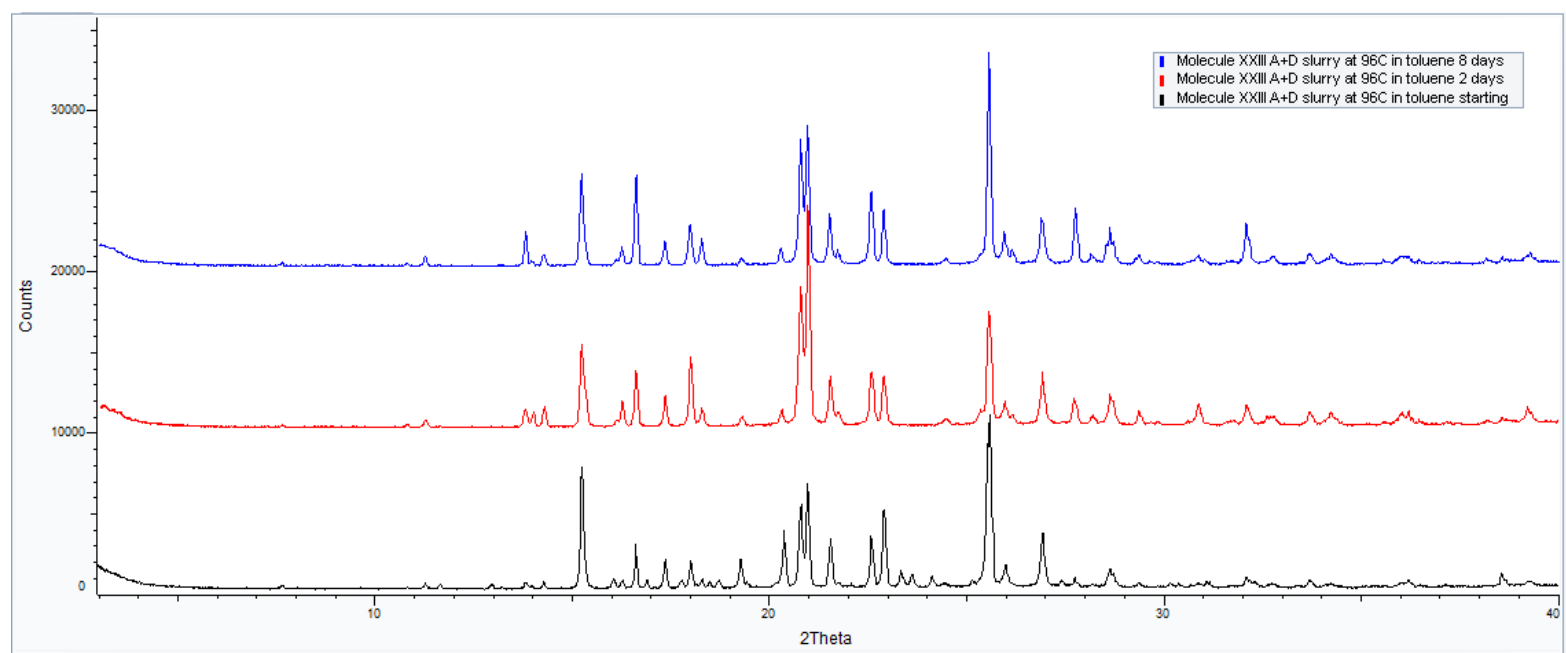

Figure S 75. Overlay PXRD patterns of Molecule XXIII Form A and D slurry in toluene at $96^{\circ} \mathrm{C}$

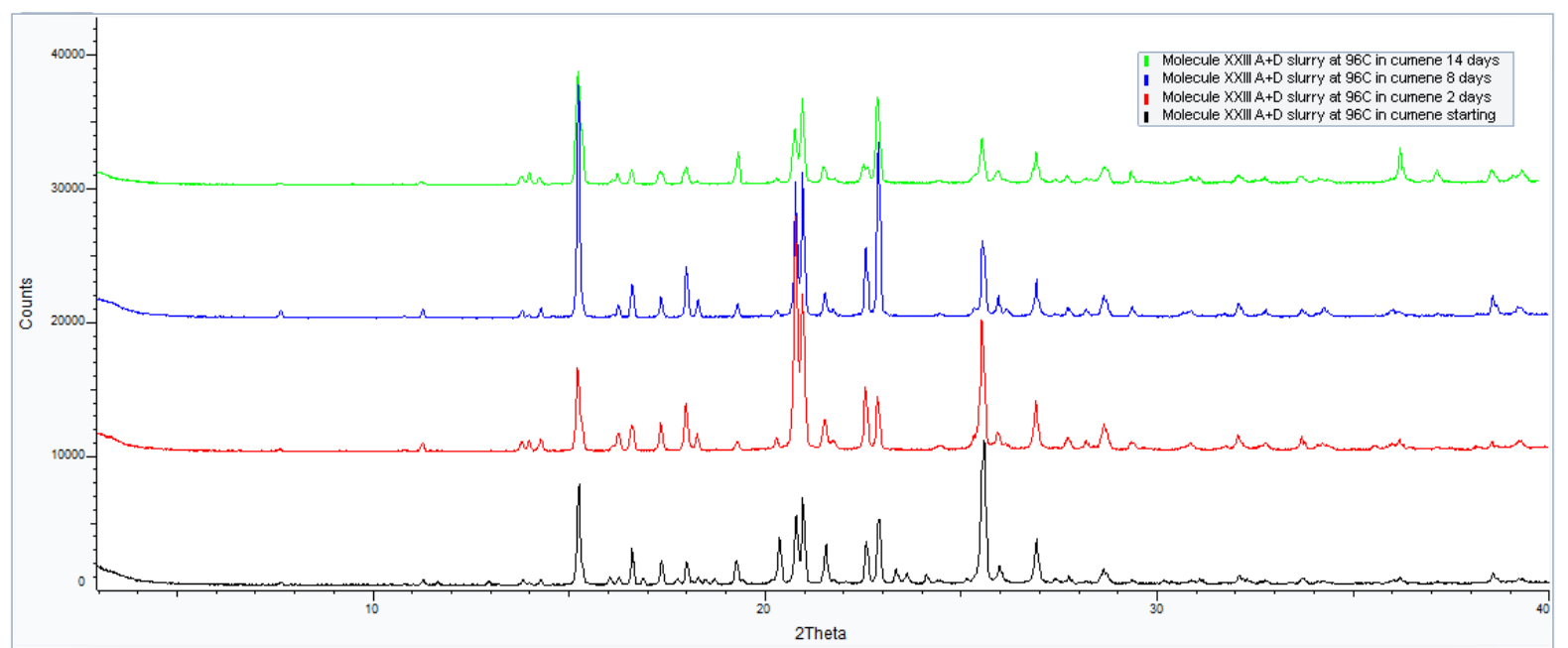

Figure S 76. Overlay PXRD patterns of Molecule XXIII Form A and D slurry in cumene at $96^{\circ} \mathrm{C}$ 
Table S 18. Slurry experiments of Molecule XXIII at $-21^{\circ} \mathrm{C}$

\begin{tabular}{|c|c|c|c|c|c|c|c|}
\hline Temperature, ${ }^{\circ} \mathrm{C}$ & Solvent & \multicolumn{6}{|c|}{ PXRD } \\
\cline { 3 - 7 } & & starting & 1 day & 6 days & 9 days & 14 days & 26 days \\
\hline$-21^{\circ} \mathrm{C}$ & 2-methyl THF & D+A & $\mathrm{C}+$ little B & $\mathrm{C}$ & $\mathrm{C}$ & $\mathrm{C}$ & $\mathrm{C}$ \\
\hline
\end{tabular}

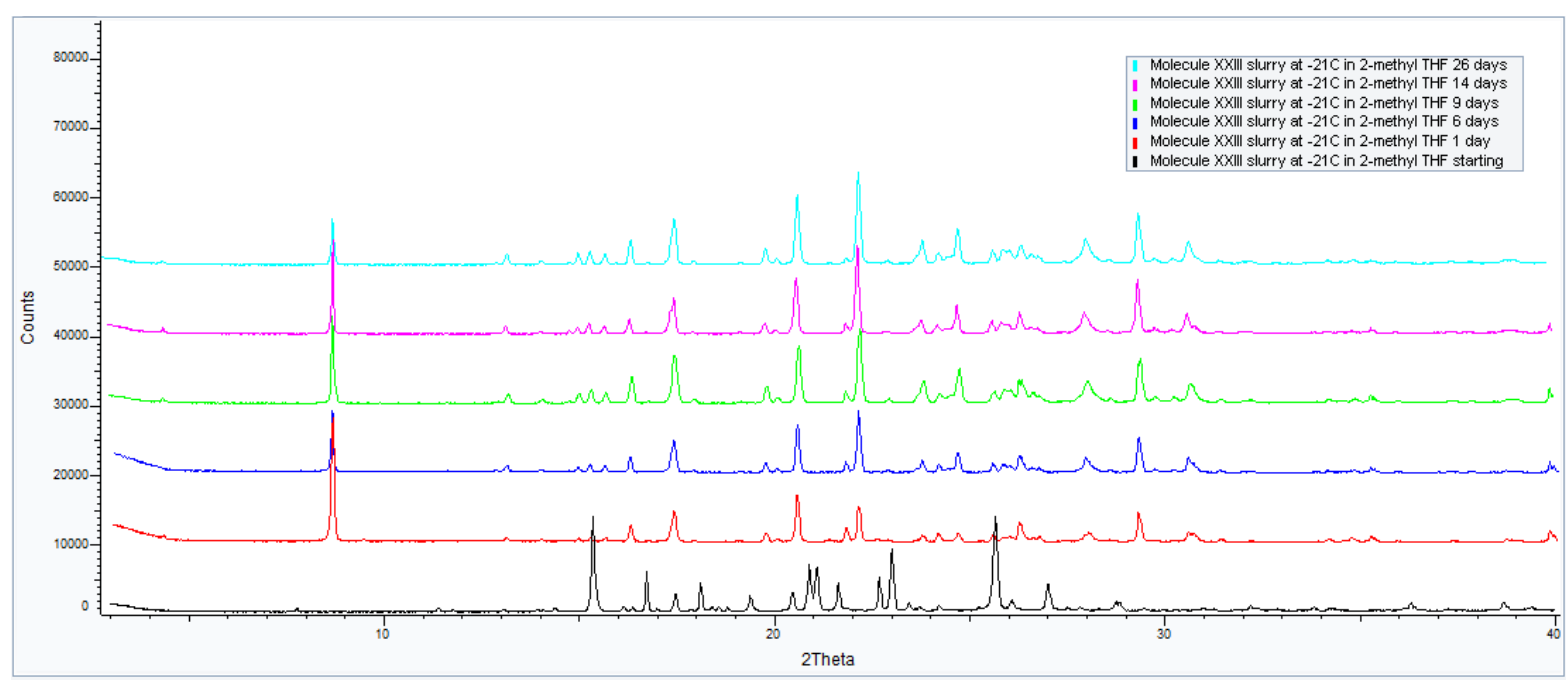

Figure S 77. Overlay PXRD patterns of Molecule XXIII slurry in 2-methyl THF at $-21^{\circ} \mathrm{C}$

Table S 19. Slurry experiments of Molecule XXIII Form A at room temperature $\left(21-22^{\circ} \mathrm{C}\right)$

\begin{tabular}{|c|c|c|c|c|c|c|}
\hline \multirow{2}{*}{ Temperature, ${ }^{\circ} \mathrm{C}$} & \multirow{2}{*}{ Solvent } & \multicolumn{5}{|c|}{ PXRD } \\
\cline { 3 - 6 } & & starting & 1 month & 2 months & 3 months & 4 months \\
\hline RT $\left(21-22^{\circ} \mathrm{C}\right)$ & Ethyl acetate & A & A & A & A & A \\
\hline
\end{tabular}

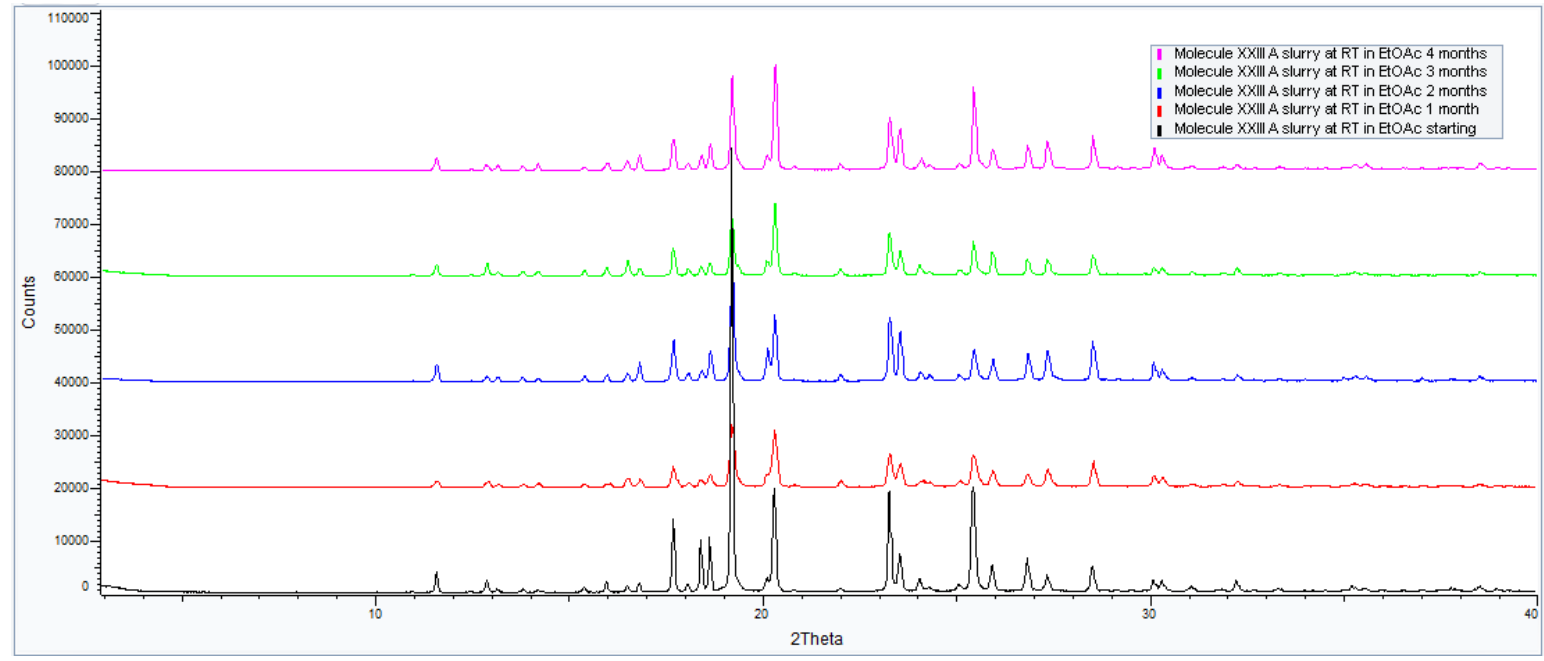

Figure S 78. Overlay PXRD patterns of Molecule XXIII Form A slurry in ethyl acetate at RT 


\section{COMPUTATIONAL ANALYSES}

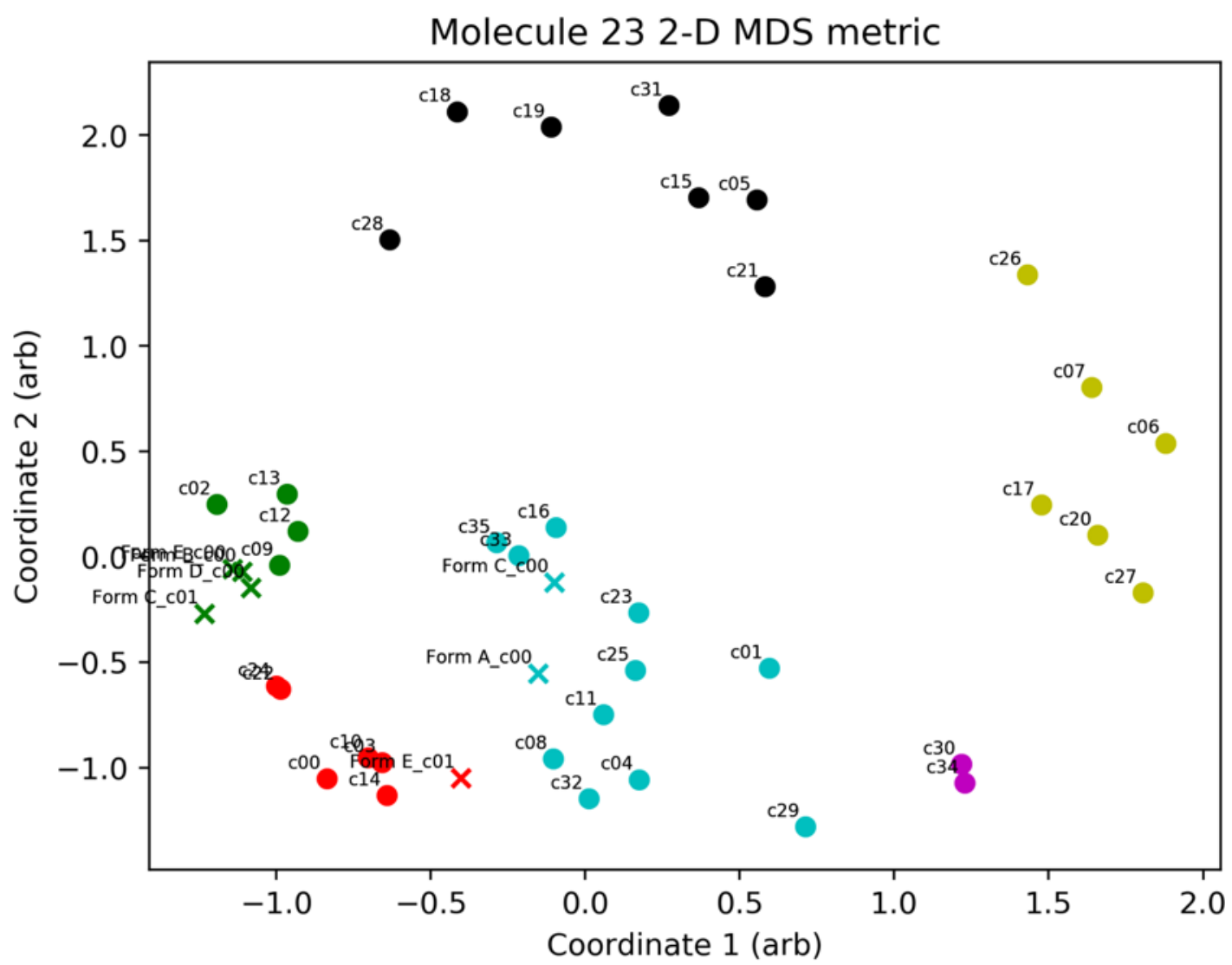

Figure S 79. 2D metric multi-dimensional scaling analysis is used to visualize the conformational similarity data in a 2D descriptor space. Similar conformations are located in proximity to each other. Experimentally observed conformations (from the SXRD data) are marked with an ' $x$ ', while putative conformations generated with the computational workflow are marked with a ' $\bullet$ '. Colors denote cluster membership and are consistent with other figures in this work. From this figure, we observe that the proposed cluster membership is reasonable, because like colored scatter points are all located in proximity to each other (i.e. green is with green, yellow with yellow, etc.). 


\section{SOLVENT INDEX TABLE}

Table S 20. Solvents considered for the computational prediction of molecular conformers in solution. The associated index can be used to reference populations of specific conformers in Figure 5 in the main text.

\begin{tabular}{|c|c|c|c|}
\hline Index & Solvent Name & Index & Solvent Name \\
\hline 0 & gas & 70 & 2,4,6-collidine \\
\hline 1 & $\mathrm{cf} 3 \mathrm{br}$ & 71 & methanol \\
\hline 2 & dimethylsulfoxide & 72 & 1,2-dichloroethane \\
\hline 3 & formaldehyde & 73 & glycol \\
\hline 4 & tetrahydrothiophene-1,1-dioxide & 74 & diisopropylether \\
\hline 5 & acetonitrile & 75 & glycerol \\
\hline 6 & gamma-butyrolactone & 76 & 1,1-dichloro-1-fluoroethane \\
\hline 7 & dimethylformamide & 77 & benzylalcohol \\
\hline 8 & acetaldehyde & 78 & 1,4-pentanediol \\
\hline 9 & methylformate & 79 & 5-hexen-2-ol \\
\hline 10 & n,n-dimethylacetamide & 80 & ethanol \\
\hline 11 & n-methyl-2-pyrrolidinone & 81 & 1,1-dichloroethylene \\
\hline 12 & propanone & 82 & 2-methyl-2,4-pentanediol \\
\hline 13 & dimethylsuccinate & 83 & isopropylbutadecanoate \\
\hline 14 & dioxane & 84 & propyleneglycol \\
\hline 15 & trimethoxymethane & 85 & propionicacid \\
\hline 16 & benzonitrile & 86 & pyrrolidine \\
\hline 17 & ethylacetate & 87 & 1,1,1-trichloroethane \\
\hline 18 & hexamethylphosphoramide & 88 & 2-propanol \\
\hline 19 & 2-pyrrolidon & 89 & 3-chloro-2-butanol \\
\hline 20 & nitrobenzene & 90 & di-tert-butylether \\
\hline 21 & butanone & 91 & propanol \\
\hline 22 & nitromethane & 92 & tetrachloroethene \\
\hline 23 & diglyme & 93 & tert-butanol \\
\hline 24 & 1-methylimidazol & 94 & 2-butanol \\
\hline 25 & dimethoxymethane & 95 & $\mathrm{cfcl} 3$ \\
\hline 26 & hexafluorobenzene & 96 & hexamethylphosphotriamide \\
\hline 27 & triethylphosphate & 97 & 4,4,4-trifluorobutanol \\
\hline 28 & n-propylacetate & 98 & formamide \\
\hline 29 & isopropylacetate & 99 & trichloroethene \\
\hline 30 & 1,2-dimethoxybenzene & 100 & 1-butanol \\
\hline 31 & benzene & 101 & 2-methyl-2-butanol \\
\hline 32 & styrene & 102 & pentane \\
\hline 33 & 1,1-dimethoxyethane & 103 & 2,2,4-trimethylpentane \\
\hline 34 & fluorobenzene & 104 & $\operatorname{ch} 2 \mathrm{cl} 2$ \\
\hline 35 & n,n-dimethylaniline & 105 & hexane \\
\hline 36 & thf & 106 & n-heptane \\
\hline 37 & diphenylether & 107 & octane \\
\hline 38 & anisole & 108 & cyclopentane \\
\hline 39 & n-butylacetate & 109 & 2,4-dimethyl-3-pentanol \\
\hline 40 & diethyleneglycol & 110 & n-decane \\
\hline 41 & triethanolamine & 111 & 2,3-dimethyl-3-pentanol \\
\hline 42 & 4-methylpyridine & 112 & isopentanol \\
\hline 43 & toluene & 113 & 1,1,2-trichloroethane \\
\hline 44 & $2,3,4,6,7,8,9,10$-octahydropyrimido[1,2-a]azepine & 114 & dodecane \\
\hline 45 & 2-methoxyethanol & 115 & 4-methyl-1-pentanol \\
\hline 46 & 4-methyl-2-pentanone & 116 & isobutanol \\
\hline 47 & n,n-diethyl-benzeneamine & 117 & methylcyclohexane \\
\hline 48 & dibutylphthalate & 118 & cyclohexane \\
\hline 49 & diethyleneglycolmonoethylether & 119 & 1-pentanol \\
\hline 50 & 1,2-dimethylbenzene & 120 & cyclooctane \\
\hline 51 & ethoxybenzene & 121 & 2,4-dimethyl-2-pentanol \\
\hline 52 & 3,5-dimethylpyridine & 122 & cis-decalin \\
\hline 53 & 2-methyltetrahydrofuran & 123 & 3-ethyl-2-methyl-3-pentanol \\
\hline
\end{tabular}


Five Degrees of Separation: Characterization and Temperature Stability Profiles for the Polymorphs of PD-0118057 (Molecule XXIII)- Supporting Information

$\begin{array}{llll}54 & \text { thp } & 124 & \text { 2-methyl-1-butanol } \\ 55 & \text { chlorobenzene } & 125 & \text { pinacolylalcohol } \\ 56 & \text { ethylbenzene } & 126 & \text { 2-hexanol } \\ 57 & \text { n-methylmorpholine } & 127 & \text { ascorbicacid } \\ 58 & \text { ethoxyethanol } & 128 & \text { 1-octanol } \\ 59 & \text { 1,2,4-trimethylbenzene } & 129 & \text { oleyl-alcohol } \\ 60 & \text { 1,1-diethoxyethane } & 130 & \text { cis-9-octadecenoicacid } \\ 61 & \text { dipropyleneglycol } & 131 & \text { chcl3 } \\ 62 & \text { isopropylbenzene } & 132 & \text { pyrrole } \\ 63 & \text { n-propylbenzene } & 133 & \text { phosphorousacid } \\ 64 & \text { tetralin } & 134 & \text { 2,2,2-trifluoroethanol } \\ 65 & \text { 2,6-dimethylpyridine } & 135 & \text { 2-methylphenol } \\ 66 & \text { methyl-t-butylether } & 136 & \text { h2o } \\ 67 & \text { 1,2-dichlorobenzene } & & \\ 68 & \text { 1-methyl-4-isopropylbenzene } & & \\ 69 & \text { 2-phenoxyethanol } & & \\ \end{array}$




\section{UNIT CELL PARAMATERS}

Table S 21. Unit Cell Parameters for the 5 Forms of Molecule XXIII.

\begin{tabular}{|c|c|c|c|c|c|}
\hline Form & $\mathrm{A}$ & $\mathrm{B}$ & $\mathrm{C}$ & $\mathrm{D}$ & $\mathrm{E}$ \\
\hline Radiation & MoK $\alpha$ & MoK $\alpha$ & MoK $\alpha$ & MoK $\alpha$ & MoK $\alpha$ \\
\hline Temperature (K) & 299 & 299 & 301 & 301 & 292 \\
\hline Crystal System & $\mathrm{P} 2{ }_{1} / \mathrm{c}$ & $\mathrm{P}-1$ & $\mathrm{P}-1$ & $\mathrm{P} 2{ }_{1} / \mathrm{n}$ & $\mathrm{P}-1$ \\
\hline $\mathrm{a} / \overline{\mathrm{A}}$ & $11.1637(10)$ & $7.0061(13)$ & $7.6375(11)$ & $13.886(4)$ & $6.687(8)$ \\
\hline $\mathrm{b} / \AA$ & $10.5295(10)$ & $7.8047(15)$ & $12.0393(17$ & $10.728(3)$ & $12.180(18)$ \\
\hline $\mathrm{c} / \AA$ & $16.2358(15)$ & $18.893(4)$ & $20.443(3)$ & $14.078(4)$ & $24.390(4)$ \\
\hline$\alpha / 0$ & 90.0 & $85.277(4)$ & $84.790(3)$ & 90.0 & $102.88(3)$ \\
\hline$\beta / 0$ & $95.749(2)$ & $80.753(4)$ & $85.379(4)$ & $113.632(5)$ & $96.69(2)$ \\
\hline$\gamma / 0$ & 90.0 & $65.769(3)$ & $80.091(3)$ & 90.0 & $97.215(15)$ \\
\hline Cell Volume $\AA^{3}$ & $1898.9(3)$ & $929.7(3)$ & $1840.0(5)$ & 1921.3(9) & $1899(5)$ \\
\hline $\mathrm{Z}$ & 4 & 2 & 4 & 4 & 4 \\
\hline $\begin{array}{l}\text { Density } / \mathrm{Mg} / \mathrm{m}^{3} \\
\left(\text { or }^{*} \mathrm{~cm}^{-3} \text { ) }\right.\end{array}$ & 1.351 & 1.380 & 1.394 & 1.335 & 1.351 \\
\hline Rint & 0.0895 & 0.0754 & 0.1623 & 0.0908 & 0.071 \\
\hline $\mathrm{S}$ & 1.028 & 1.096 & 0.835 & 1.002 & 1.028 \\
\hline $\mathrm{R} 1$ & 0.0529 & 0.0524 & 0.0686 & 0.0672 & 0.1038 \\
\hline wR2 & 0.1660 & 0.1548 & 0.1654 & 0.1916 & 0.3191 \\
\hline
\end{tabular}

